\title{
A NEW COPYRIGHT ORDER: WHY NATIONAL COURTS SHOULD CREATE GLOBAL NORMS
}

\author{
GRAEME B. DINWOODIE ${ }^{\dagger}$
}

INTRODUCTION.

I. THE DEMANDS OF COPYRIGHT LAWMAKING IN THE TWENTY-FIRST CENTURY

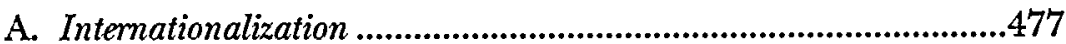

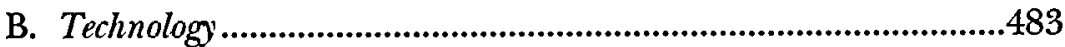

G. The Reach of Copyright Law ........................................................486

II. PUBLIC INTERNATIONAL COPYRIGHT LAWMAKING .......................4489

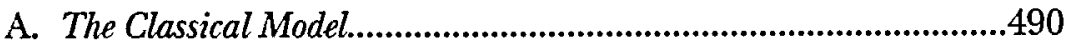

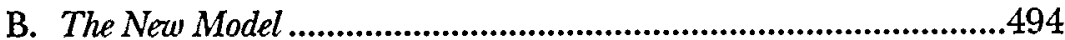

C. Dispute Settlement in Public International Copyright Law ..............501

1. The Apparent Potential of the WTO ...................................501

2. Resisting an Activist Interpretive Philosophy in the WTO

a. The Agreements Contemplate No Dynamic Lawmaking Role for WTO Panels.......................................................504

b. Pracedural and Representational Legitimacy of WTO Panel Rulings.......................................................505

c. Insufficiently Inclusive Perspectives.......................................508

i. In the Initiation and Conduct of Claims ................508

ii. In the Resolution of Disputes................................510

d. Premature Entrenchment of Fundamental Norms ................512

i. Erosion of Appropriate National Autonomy ...........513

ii. Foreclosing the Laboratory Role of Nations...........514

iii. Problems of TRIPS Interpretation ...........................515

† Professor of Law, Chicago-Kent College of Law. The ideas developed in this Article benefited greatly from presentations made to the Faculty Workshop at the University of Pennsylvania Law School, the Summer Scholarship Luncheon Series at the University of Cincinnati College of Law, the Interdisciplinary Conference on the Impact of Technological Change on the Creation, Dissemination, and Protection of Intellectual Property at Ohio State University, and the Colloquium on Innovation Policy: Remapping Intellectual Property Law For a Changing Business Environment, at the New York University School of Law. I am also indebted to many colleagues for insightful and constructive comments on earlier drafts of this Article, including Brian Havel, Rochelle Dreyfuss, Bob Gorman, Jerry Reichman, Paul Stephan, Shira Perlmutter, Michael Van Alstine, Michael Solimine, and Wendy Parker. Finally, I am very grateful to Alicia Hickok, Michelle Paninopoulos, and Sasson Marcus for splendid research assistance. All views expressed, and any errors that remain, are mine alone. 
D. Rejecting Internationalization?.

III. PRIVATE INTERNATIONAL COPYRIGHT LAWMAKING ........................521

A. International Copyright Arbitration ............................................522

B. Choice of Law Analysis in Copyright Litigation .............................528

1. The Territoriality of Copyright Law.....................................528

2. Traditional Approaches to Choice of Law in Copyright

3. A New Approach to Choice of Law in International Copyright Cases: The Substantive Law Method

a. Historical and Scholarly Support.....................................543

b. The Basic Approach ..............................................................545

i. Theoretical Basis .....................................................545

ii. Sources of Law ...................................................552

iii. Application of the Substantive Law Method............558

c. Advantages as an Instrument of International Copyright Lawmaking.....................................................569

d. Troublesome Issues...........................................................571

i. Certainty ................................................................571

ii. Legitimacy .............................................................575

iii. Biases Inherent in the Nature of

International Litigation .........................................577

CONCLUSION. .579

\section{INTRODUCTION}

A pervasive sentiment expressed by copyright scholars and by policymakers in the field is the need for international solutions to figure prominently in the reform and evolution of present law. The

${ }^{1}$ See, e.g., BRUCE A. LEHMAN, INTELIECtUAL PROPERTY AND the NATIONAL, INFORMATION INFRASTRUCTURE: THE REPORT OF THE WORKING GROUP ON INTELLECTUAL PROPERTY RIGHTS 10, 117-19, 139 (1995) [hereinafter WHITE PAPER] (emphasizing that the development of intellectual property rules in the digital environment requires attention to protection internationally); Proposal for a European Parliament and Council Directive on the Harmonization of Certain Aspects of Copyright and Related Rights in the Information Society, COM(97)628 final at 14 (noting that the implementation of recent treaty obligations was the "principal foundation" of the Commission's proposals for adaptation of copyright law to the digital age, and recognizing that the proposed reforms could not afford to focus solely on domestic internal market objectives); Dan L. Burk, Transborder Intellectual Property Issues on the Electronic Frontier, 6 STAN. L. \& POL'Y REV. 9, 15 (1994) (discussing the alternative means by which to address the transborder nature of information flow); Gillian Davies, The Convergence of Copyright and Authors' Rights-Reality or Chimera?, 26 INT'L REV. INDUS. PROP. \& COPYRIGHT L. 964, 988 (1995) (arguing that "[i]t should be a priority ... to steer clear of theological debates about the respective merits of various national approaches and to seek solutions and an international framework which can accommodate both the common law and civil law approaches [to authors' rights]"); Laurence R. Helfer, 
need to develop international solutions, and hence to incorporate global values and policies in the lawmaking process, is scarcely unique to copyright law. But the effect of digital technology upon the creation, delivery, and use of copyrighted works has made such internationalization appear more urgent in copyright than in other areas of law. Indeed, it is a truism that contemporary problems in copyright law demand international solutions.

But what does it mean to develop international solutions, and how is such internationalization to be achieved? On this point, there is less consensus and often too little analysis. For example, a recent report by the National Research Council on the challenges raised by digital networks, The Digital Dilemma: Intellectual Property in the Information Age, notes the unquestioned need to address the most pressing issues in copyright law in a worldwide context, but then proceeds to perform a purely domestic analysis of those issues. ${ }^{2}$ This token acknowledgment of the importance of the international dimension, and the difficulties that it presents, is not unusual; because the basic proposition is largely unchallenged, there often appears little effort to understand its precise significance. "Internationalization" is treated as a given, without considering what it means.

In this Article, I explore the different means by which international copyright solutions are being, and should be, developed. My conclusions flow in large part from analysis of three other truisms of contemporary copyright thought discussed in Part I. First, copyright law must accommodate and respond to technological developments; second, copyright law is an essential instrument of national cultural and information policy; and, third, copyright law affects an ever

Adjudicating Copyright Claims Under the TRIPS Agreement: The Case for a European Human Rights Analogy, 39 HARV. INT'L L.J. 357 (1998) (discussing the role of World Trade Organization dispute settlement panels in the development of copyright law); Marshall A. Leaffer, Protecting United States Intellectual Property Abroad: Toward a New Multilateralism, 76 IOWA L. REv. 273 (1991) (examining reasons for developed and developing countries to seek development and enforcement of international intellectual property standards). Such convictions are not wholly new. See Zechariah Chafee, Jr., Reflections on the Law of Copyright, 45 CoLuM. L. REV. 503, 505-06 (1945) (noting that "art and literature have always been international in spirit" and suggesting that "international copyright... will eventually become more desirable than ever before on account of the growing cultural interdependence of the world and our hopes for a measure of political interdependence").

2 See National Research COUNCIL, The Digttal DILEMMa: INTEllectual PROPERTY IN THE INFORMLATION AGE 6 (2000) [hereinafter DigITAL DILEMMA] (focusing the report on U.S. law, but noting the need for conclusions about important intellectual property issues to be considered in a global context).

"See Jane C. Ginsburg, International Copyright: From a "Bundle" of National Copyright Laws to a Supranational Code?, 47 J. CopxRIGHT Soc'Y 265, 267 (2000) ("National copy- 
larger and more diverse set of societal interests. ${ }^{4}$ These three considerations require in turn that copyright lawmaking be receptive to dynamic, prospective adaptation, that its results permit some room for national variation, and that it accommodate pluralistic perspectives.

I conclude in Part II that although classical public international copyright lawmaking ${ }^{5}$ affords great latitude for national heterogeneity, and does not inherently or affirmatively exclude diverse perspectives, it fails adequately to reflect the first of these concerns. As a result of its backward-looking character, public international lawmaking adopts a codifying rather than a dynamic character. On one level, I do not find this troubling: the caution inherent in the classical model arises in part out of a commendable concern for national autonomy and international diversity, and such caution will be even more important if public international lawmaking truly takes into account the contemporary need for accommodating a greater variety of perspectives. Thus, I accept that the proper role for public international lawmaking is to reflect a growing consensus among nation-states. Rather, the disposition of classical public international copyright law merely high-

right laws are a component of local cultural and information policies. As such, they express each sovereign nation's aspirations for its citizens' exposure to works of authorship, for their participation in their country's cultural patrimony."); Barbara A. Ringer, The Role of the United States in International Copyright-Past, Present, and Future, 56 GEO. L.J. 1050, 1050 (1968) ("Though their true influence is dimly understood at best, a nation's copyright laws lie at the roots of its culture and intellectual climate. Copyright provides the inducement for creation and dissemination of the works that shape our society and, in an imperfect and almost accidental way, represents one of the foundations upon which freedom of expression rests.").

${ }^{4}$ See DIGITAL DILEMMA, supra note 2, at 4-5 (noting the wide variety of stakeholders with concerns about the impact of intellectual property law).

${ }^{5}$ By public international copyright lawmaking, I mean activity that occurs between or among nation-states (or authorized groupings thereof, such as the European Union). This includes, for example, negotiation of treaties or state-to-state dispute resolution before a tribunal (such as the International Court of Justice or a World Trade Organization dispute settlement panel). I use the term in contrast to private international lawmaking activities, by which I mean activities by private nongovernmental actors that contribute to international lawmaking. In this category I include, most prominently, international commercial arbitration and transnational copyright litigation in national courts. The line between the public and private processes is of course challenged by a variety of institutional arrangements, such as the UNIDROIT or UNCITRAL conventions. See Michael P. Van Alstine, Dynamic Treaty Interpretation, 146 U. PA. L. REv. 687, 726-31 (1998) (noting parallels and differences between the Convention on the International Sale of Goods and public international agreements). But, as I explain more fully below, my thesis is that aspects of both what I call "public international copyright lawmaking" and "private international copyright lawmaking" should contribute to the process of internationalization, see infra Part III, and thus I use the contrasting terms merely as shorthand for conventional understandings of lawmaking processes. 
lights the inability of that form of lawmaking to serve as the sole means of pursuing internationalist goals while accommodating other competing considerations.

But the classical model, as I explain in Part II of this Article, no longer prevails unchallenged. The 1990s ushered in a new era of public international copyright lawmaking. Under the new model, relationships among national, regional, and international institutions are consciously more fluid; the pressures to reach (particular forms of) international agreement are strategically heightened by frenetic lawmaking activity in an increased range of institutions; and effective procedures for enforcing international standards have been put in place, thus transforming copyright law into a justiciable body of law. As Part II discusses, the institutional mechanisms of this new model may appear to supply_and some policymakers may wish them to supply-the prospective dynamism missing from the classical model.

The dispute settlement system ${ }^{6}$ of the World Trade Organization ("WTO"), within which the substantive public international obligations imposed by the Agreement on Trade Related Aspects of Intellectual Property ("the TRIPS Agreement") ${ }^{8}$ were subsumed, possesses the most potential in this regard. I argue, however, that an aggressive use of WTO dispute settlement proceedings, or more importantly the adoption of an activist interpretive philosophy by panels ${ }^{9}$ that are con-

"See Understanding on Rules and Procedures Governing the Settlement of Disputes, Apr. 15, 1994, Marrakesh Agreement Establishing the World Trade Organization [hereinafter WTO Agreement], Annex 2, LEGAL INSTRUMENTS-RESULTS OF THE URUGUAY ROUND vol. 31, 33 I.L.M. 112 (1994) [hereinafter DSU] (establishing the rules and procedures to be used in WTO dispute settlement proceedings).

${ }^{7}$ See WTO Agreement (establishing the WTO).

*Agreement on Trade-Related Aspects of Intellectual Property Rights, Apr. 15, 1994, WTO Agreement Annex 1C, LEGAL INSTRUMENTS-RESULTS OF THE URUGUAY RoUND, vol. 31, 33 I.L.M. 1197 (1994) [hereinafter TRIPS or the TRIPS Agreement]. The TRIPS Agreement is one component of the trade agreement establishing the WTO emanating from the Uruguay Round revision of the General Agreement on Tariffs and Trade ("GATT"). It includes provisions on all aspects of intellectual property, including patent, trademark, design protection, trade secrets, and geographical indications of origin, as well as copyright. See generally J.H. Reichman, Universal Minimum Standards of Intellectual Property Protection under the TRIPS Component of the WTO Agreement, 29 INT'L LAW 345 (1995) (providing an overview of the TRIPS Agreement).

If one member state of the WTO is alleged by another to be in violation of TRIPS, the member states will first enter into consultations with each other. If those consultations fail to produce a resolution of the dispute, a panel of the WTO Dispute Settlement Body ("DSB") may be convened at the instance of the complaining party. See DSU art. 6 (outlining the procedures for establishing dispute settlement panels). Panel decisions are appealable to a standing Appellate Body of the DSB. See id., art. 17. References in this Article to WTO panels or the WTO DSB encompass both the panels 
vened under WTO auspices, would be counter-productive. It might supply the dynamism missing from the classical model, but it would do so at the cost of other relevant concerns, namely national diversity and pluralistic perspective. Thus, although TRIPS has had, and the WTO will have, an important role in providing an international dimension to copyright lawmaking, such new public international copyright lawmaking must not be unrestrained. ${ }^{10}$

Instead, I argue in Part III for a broader, more expansive notion of international copyright lawmaking. In particular, I stress that the internationalization of copyright law may take forms other than formal declarations of binding rules of public international law, and suggest that the properly confined role of public international copyright lawmaking should consciously be supplemented by private international copyright lawmaking. " By this, I mean that private law dispute

and the Appellate Body unless the contrary intent is expressly stated.

${ }^{10}$ I do conceive a role for public international copyright lawmaking. Public international copyright lawmaking has clearly contributed to the convergence of disparate national systems of copyright. See Davies, supra note 1, at 978-87 (discussing the role of the World Intellectual Property Organization ("WIPO"), TRIPS, and the European Union ("EU") in effecting convergence). A range of different institutional alternatives will be helpful in developing a variety of solutions to ongoing international problems. Just as the different pressures and context of the WIPO and the WTO may generate different solutions, see Frederick M. Abbott, The Future of the Multilateral Trading System in the Context of TRIPS, 20 HASTINGS INT'L \& COMP. L. REV. 661, 676-82 (1997) (discussing relationship between the WTO and the WIPO), a greater range of options is likely to come from an institutional smorgasbord that comprises national, regional, and international solutions on both the private and public law sides.

${ }^{11}$ This Article focuses on the incorporation of international norms into copyright law alone because it is useful to consider these questions in concrete settings; the respective roles of different international institutions and mechanisms may vary depending upon the content of the law in question. It is not clear, for example, that trademark implicates the same nontrade values that might make WTO resolution of certain copyright issues less than fully dimensional. See infra Part II.C.2.c.ii (discussing the ability of WTO panels to consider the full range of copyright values). Moreover, although some of my observations regarding the role of private international lawmaking clearly apply beyond intellectual property law, copyright is a particularly opportune subject of study because the last few years have seen (and I predict, the coming years will see) significant resort to a variety of the institutions and mechanisms discussed herein. Important treaties, such as the once-shelved Database Treaty, remain pending, regional legislative activity continues apace in the $E U$, and international copyright obligations are now being undertaken in the shadow of effective international enforcement mechanisms. In June 2000, a WTO dispute settlement panel handed down the first report on a copyright dispute arising under TRIPS. See United States-Section 110 (5) of the U.S. Copyright Act: Report of the Panel, WT/DS160/R (June 15, 2000), at http://www.wto.org (finding the U.S. Fairness in Music Licensing Act to be in violation of TRIPS). See generally Laurence R. Helfer, World Music on a U.S. Stage: A Berne/TRPS and Economic Analysis of the Faimess in Music Licensing Act, 80 B.U. L. REv. 93, 141-85 (2000) (analyzing possible conflicts between the Fairness in Music Licensing Act and the TRIPS Agreement and the Berne Convention). And the five-year morato- 
settlement mechanisms should play an important role in the internationalization process. Rather than embrace the new public international lawmaking process as the holy grail of copyright internationalization, I seek to accommodate the competing concerns of dynamism, national diversity, and pluralistic perspective by broadening the means by which international norms work to infiltrate domestic copyright law.

Part III of the Article, therefore, explores the ways in which private law mechanisms are, and could be, used to develop international copyright law. First, I consider whether arbitration of copyright disputes possesses the potential to exert influence upon the development of international copyright norms. International commercial arbitration proceedings make frequent reference to a lex mercatoria, ${ }^{12}$ emanating from standards of international commerce rather than from any particular national norms, that could, with appropriate adaptation, contribute to the development of international copyright standards. I conclude that the use of cybercontractual arrangements in the supply of copyrighted works makes arbitration based upon ex ante agreement a more likely resource for copyright development than was previously the case because such arrangements create contractual privity between copyright disputants typically not found in the bricks-andmortar world.

Second, and central to this Article, I seek to enlist national courts in the task of copyright internationalization by sketching a new choice of law methodology for private international copyright disputes. All current approaches to choice of law force courts to fictionalize multinational disputes as implicating purely national norms (the process of "localization"), and thus foreclose the consideration by courts of international norms separate and apart from domestic policy objectives. Each of these approaches requires courts to decide issues raised by such disputes according to a single national law. ${ }^{13}$ Instead, I propose

rium on TRIPS nonviolation complaints, which may test the outer boundaries of the WTO dispute settlement system, expired on January 1, 2000. See infra note 105 (discussing the history of the nonviolation complaint moratorium and its status postJanuary 1, 2000).

" See infra text accompanying notes 165-66 (discussing international commercial arbitration).

"The doctrine of dépeçage permits courts to apply the law of one state to one issue in a litigation before it and the law of another state to a separate issue in the same litigation. It thus recasts the choice of law exercise as an effort to select the law applicable to decide an issue rather than a case. See Willis L. M. Reese, Dépeşage: A Common Phenomenon in Choice of Law, 73 ColuM. L. REv. 58, 58 (1973) (describing the doctrine of depeçage). The doctrine has recently been applied by U.S. courts in copyright 
that courts should decide international copyright cases not by choosing an applicable law, but by devising an applicable solution. International copyright disputes implicate interests beyond those at stake in purely domestic copyright cases. National courts should thus be free to decide an issue in an international case using different substantive copyright rules that reflect not only a single national law, but rather the values of all interested systems (national and international) that may have a prescriptive claim on the outcome. This approach to choice of law may unleash the generative power of common law adjudication as a means of developing international copyright norms. And it would accommodate the concerns of dynamic flexibility without compromising the values of national diversity or pluralistic perspective in a way that public law-based copyright lawmaking does not.

Before proceeding, one caveat is in order. In this Article, I focus largely on questions of process in copyright law formation. ${ }^{14}$ To be sure, those questions cannot be wholly divorced from the substantive aims of copyright law, and the particular substantive rules of copyright law that emerge are not unaffected by the process that gives birth to them. But whether temporary copying should constitute prima facie reproduction, whether browsing should be conceptualized as copying, or whether database protections should include sole-source compulsory licenses-and many other questions raised by global digitization-are topics worthy of separate and sustained analysis. Others are doing that work. For current purposes, I want to explore the process of internationalizing copyright law. That exploration will inevitably impinge upon substantive concerns, and the conclusions that I reach will surely be viewed by others more or less favorably depending upon the extent to which they impede or further particular substantive goals. But this merely highlights the importance of attention to process in and of itself.

cases. See, e.g., Itar-Tass Russ. News Agency v. Russ. Kurier, Inc., 153 F.3d 82, 89-92 (2d Cir. 1998) (applying Russian law to ownership question and U.S. law to infringement question); see also Bridgeman Art Library, Ltd. v. Corel Corp., 25 F. Supp. 2d 421 (S.D.N.Y. 1998) (acknowledging relevance of issue by issue analysis in copyright dispute involving protection for United Kingdom works in the United States), aff'd on reconsideration, 36 F. Supp. 2d 191 (S.D.N.Y. 1999). The doctrine bears some similarity to the approach proposed in this Article in that a court may ultimately generate a result that would not have ensued under any single national law. Even under dépeçage, however, the forum will apply the law of a single state to each of the issues with which it is presented (even if a different national law might be applied to a different issue in the same analysis).

${ }^{14}$ Cf. Paul B. Stephan, The Futility of Unification and Harmonization in International Commercial Law, 39 VA. J. INT'L L. 743, 796 (1999) (attempting to "shift the focus of private international law scholarship from substantive law to the lawmaking process"). 


\section{THE DEMLANDS OF COPYRIGHT LAMMLAKING IN THE TWENTY-FIRST CENTURY}

Copyright law stands at the junction of powerful pressures that may impose sometimes inconsistent prescriptive demands. Globalization requires that problems be addressed as an international matter. Technology, by significantly altering the means by which copyrighted works are created, the ways in which they are distributed, and the manner in which they are used, has yoked the content of copyright law to fast-changing developments. And these changes have brought questions of copyright more directly into the lives of a greater number of people and into the business affairs of a greater number and range of commercial concerns. In this Part, I outline these pressures and the nature of the demands that they impose upon copyright lawmaking.

\section{A. Internationalization}

Almost every significant reform of U.S. copyright law over the last twelve years, since the United States belatedly joined the Berne Convention $^{15}$ in 1988, has reflected international influences. ${ }^{16}$ The nature and extent of the influence has varied: explicitly implementing treaty obligations; ${ }^{17}$ embracing (somewhat) more fully the spirit of obligations that were previously accepted with marked reluctance; ${ }^{18}$ respond-

15 Berne Convention for The Protection of Literary and Artistic Works, July 24, 1971,1161 U.N.T.S. 3 [hereinafter Berne Convention]. The first version of the Berne Convention was concluded in 1886. See generally SAM RICKETSON, THE BERNE CONVENTION FOR THE PROTECTION OF LITERARY AND ARTISTIC WORKS: 1886-1986 (1987) (tracing the development of the Berne Convention).

1i. This is not to say that domestic developments prior to 1988 did not also reflect international considerations. Indeed, many of the significant reforms effected by the 1976 Copyright Revision Act, such as revisions to the copyright term or moderation of the consequences of publication without copyright notice, were motivated by the desire to bring the United States closer to compliance with the Berne Convention. See H.R. REP. NO. 94-1476, at 135-36 (1976), reprinted in U.S.C.C.A.N. 5659 (identifying adherence to the Berne Convention as an argument for reform of U.S. copyright law).

${ }^{17}$ See, e.g., Digital Millennium Copyright Act, Pub. L. No. 105-304, 112 Stat. 2860 (1998) (implementing the WIPO Copyright Treaty and the WIPO Performances and Phonograms Treaty); Uruguay Round Agreements Act, Pub. L. No. 103-465, 108 Stat. 4809 (1994) (implementing the Uruguay Round Agreements); Berne Convention Implementation Act of 1988, Pub. L. No. 100-568, 102 Stat. 2853 (revising provisions necessary to permit adherence to the Berne Convention).

is See, e.g., Renewal Amendments Act of 1992, Pub. L. No. 102-307, 106 Stat. 264 (1992) (eliminating a number of formalities formerly required for copyright renewal); Visual Artists Rights Act of 1990, Pub. L. No. 101-650, tit. VI, 104 Stat. 5128 (1990) (providing creators of certain works of visual art with moral rights protection); Archi- 
ing to reciprocity-conditioned foreign laws that, absent U.S. legislation, might disadvantage U.S. producers internationally; ${ }^{19}$ and, some have suggested, even using the cover of international expectations (or expansive interpretation of certain international obligations) to achieve particular domestic substantive copyright policy goals. ${ }^{20}$ Domestic legislative debate has necessarily occurred in the shadow of international events. And the picture is no different with pending copyright legislation. ${ }^{21}$

This phenomenon may reflect a trend in national legislative activity generally, but there are good reasons for this impulse in the copyright context. ${ }^{22}$ First, adequate protection for copyrighted works within the United States is a function of more than U.S. levels of protection; effective international protection has become essential, rather than merely preferable, for U.S. producers of copyrighted works. To be sure, the forces of globalization currently holding sway in the economies of the world do not represent the first wave of internationalization that mankind has encountered. The Industrial Revolution precipitated similar upsurges in technological advances and manufacturing productivity, and similarly made distance less significant. The

tectural Works Copyright Protection Act, Pub. L. No. 101-650, tit. VII, 104 Stat. 5133 (1990) (making express provision for the protection of architectural works as such).

19 See, e.g., Sonny Bono Copyright Term Extension Act, Pub. L. No. 105-298, 112 Stat. 2827 (1998) (extending the term of copyright); see also Council Directive 93/98/EEC, 1993 O.J. (L 290) 9 (harmonizing the copyright term at seventy years post mortem auctoris throughout the $\mathrm{EU}$, but conditioning the extended term for non-EU nationals on equivalent protection in the relevant non-EU state); Berne Convention, supra note 15, art. 7(8), 1161 U.N.T.S. at 37 (permitting signatory nations to apply the rule of the shorter term, that is, to limit foreign works to the term of protection offered in their country of origin).

${ }^{20}$ See Pamela Samuelson, Intellectual Property And The Digital Economy: Why The Anti-circumvention Regulations Need to Be Revised, 14 BERKELEY TECH. L.J. 519, 530-33 (1999) (discussing implementation of the WTPO Copyright Treaty); see also Pamela Samuelson, The U.S. Digital Agenda at WIPO, 37 VA. J. INT'L L. 369, 373-74 (1997) [hereinafter Samuelson, The U.S. Digital Agenda] (discussing the conclusion of the WTPO Copyright Treaty).

${ }_{21}$ See, e.g., Collections of Information Antipiracy Act, H.R. REP. No. 106-349, at 1011 (1999) (noting the relevance of international protection of databases to legislative debate); see also Directive 96/9/EC of the European Parliament and of the Council of II March 1996, on the Legal Protection of Databases, 1996 O.J. (L 77) 20 [hereinafter Database Directive] (affording sui generis protection to databases of information compiled by non-EU nationals only where reciprocal protection is available for EU nationals under third country laws).

${ }^{22}$ For a view that a substantive policy preference of altering copyright's existing "cultural bargain" lies behind the reasons offered by the Clinton Administration for the move to the international stage, see Peter A. Jaszi, Goodbye to All That-A Reluctant (and Perhaps Premature) Adieu to a Constitutionally-Grounded Discourse of Public Interest in Copyright Law, 29 VAND. J. TRANSNAT'L L. 595, 599 (1996). 
completion of the first comprehensive multilateral copyright convention, the Berne Convention in 1886, can be traced in part to a developing international market in the distribution of books. ${ }^{23}$ But, under the current manifestation that we call globalization, producers of copyrighted works are largely unable to resist expansion to the international stage of product exploitation simply because a protective legal framework is not yet in place abroad. Globalization is partly driven by users and consumers of copyrighted goods. Users of copyrighted works have greater capacity to control the materialization of intangible works, and thus to affect where such materialization occurs. ${ }^{2 .}$ Domestic distribution of a work effectively means international distribution, regardless of a producer's wishes, which in turn (because of the easy appropriation of intellectual goods) becomes competing domestic distribution. The foreign market is no longer a serial extension of the domestic market; they are one and the same. The ability of a single nation-state to implement autonomous cultural and information policies is diminishing; national policymakers need the cooperation of other nations if they wish to realize a particular goal (such as to ensure a secure environment for the creation and distribution of copyrighted works)..$^{25}$

${ }^{2}$ See RICKETSON, supra note 15 , at $18-19$ (discussing the growth of nineteenthcentury international copyright relations); STEPHEN M. STEWART, INTERNATIONAL COPYRIGHT AND NEIGHBOURING RIGHTS $\$ 1.16$, at 9-10 (2d ed. 1989) (noting the "commercial necessity" of international copyright in the nineteenth century).

${ }^{24}$ From the perspective of U.S. producers, the internationalization of markets reflects more than a response to the intangible nature of copyrighted works. It also reflects an enhanced demand abroad for products of the U.S. copyright industries. This demand, which is at once a commercial opportunity for U.S. producers and a contributing cause of their loss of control, can be attributed to a variety of factors. First, recent international cultural assimilation has tended in the direction of American culture, perhaps by virtue of U.S. domination of the internet as a medium of access to works and the sheer volume of American culture made available via satellite television. But see Pokémania $v$. globophobia, THE ECONONIST, Nov. 20, 1999, at 36 (challenging the inevitability of the domination of American pop culture as a result of globalization, and discussing the phenomena of Pokemon, from Japan, and Harry Potter and the Teletubbies, both from the United Kingdom). Second, there has been a rise in the use of the English language, facilitated in part by its being the predominant language on the internet, and the most prevalent language of internet search engines. See UNITED NATIONS, HuMAN DeVElopMENT RePORT 1999, at 6 (Oxford Univ. Press. 1999) (reporting that $80 \%$ of web sites are written in English, although less than $10 \%$ of the world's population speaks English). Finally, political liberalization (particularly in Central and Eastern Europe) and higher levels of education internationally have opened up new markets to U.S. works.

${ }^{25}$ See J.H. Reichman \& Pamela Samuelson, Intellectual Property Rights in Data?, 50 VAND. L. REV. 51, 112 n.279 (1997) (noting that “the Administration's main argument for moving so far and so fast rests largely on the supposed difficulties of enforcing ter- 
Second, divergent national laws impose significant costs on the producers of copyrighted works. Revising production and distribution practices to accommodate different national requirements burdens the producer not only with additional administrative expense, but also with escalated uncertainty about protection that will be reflected in a risk premium passed on to users. This premium must be accounted for not only in the pricing of works intentionally distributed via the global information infrastructure $;^{26}$ the widespread capacity to digitize

ritorially grounded intellectual property rights in cyberspace"). Some of these difficulties may be addressed technologically, and some commentators have placed faith, in part, upon such developments as a means of avoiding conflicts problems. See Jack L. Goldsmith, The Internet and the Abiding Significance of Territorial Sovereignty, 5 IND. J. GLOBAL LEGAL STUD. 475, 484-85 (1998) (noting the role of technology in reestablishing borders). That is, one way of avoiding the conflicts precipitated by transnational events is to ensure that all acts occur in a purely national setting. This can be pursued by legal regulation that increases the cost of foreign activity over any potential gains, or by technological erection of borders. See Denise Caruso, Digital Commerce: Control over Content, N.Y. TimEs, Mar. 13, 2000, at C4 (reporting that the response of ICraveTV.com to complaints concerning its activities, permissible in Canada but prohibited in the United States, was to pursue technological measures that would bar U.S. users from accessing the Canadian web site, and thus to create "country-area networks"). But even were such technological solutions possible, see id. (noting difficulties of creating such effective technological measures), it is uncertain whether encouraging them is advisable. Technological territorialism would discard the social gains of globalization in terms of enhanced access to a greater variety of material and frustrate the declared purpose of the leading international copyright convention, namely to promote the international dissemination of works of authorship. But cf. Goldsmith, supra, at 485 (" $[\mathrm{T}]$ here is nothing sacrosanct about ... . a foreign content provider's right to send information everywhere in the world with impunity."). And the gains of international access to information are not lightly to be discarded. Beyond the inherent value of access to a greater and more diverse universe of creative works, a value implicit in the instrumentalist notion of copyright, access to and understanding of the social and cultural conditions of others can only lead to enlightened international relations and deeper understandings of social problems. One might argue that these gains of globalization are not worth the costs that are generated, cf. Le Cyber Challenge, THE ECONOMIST, Mar. 11, 2000, at 55 (noting that the internet, and its early domination by the English language, had interfered with the "cultural policing" efforts of the Académie Française to defend the French language, and that Francophone policy is now to embrace the internet and encourage the spread of cultural diversity by promoting the spread of French sites on the internet), but difficult choice of law questions resulting from an unduly constrained methodological mindset hardly seem a persuasive cost to invoke. Surely, the potential gains of globalization command more hard thinking on the part of legal scholars than efforts to reimpose technologically the territorialism of the nineteenth and twentieth centuries.

${ }^{26}$ The risk of inadequate international protection is, of course, not entirely externally generated if the copyright owner digitizes the work itself and hence facilitates the copying and transmission of the work abroad. But the hand of the copyright owner may effectively be forced not only by the capacity of users, noted in the text, to digitize works distributed by the copyright owner in analog format, but also by the development of digital distribution mechanisms by others, including by persons other than 
analog copies of works, on a popular as well as commercial level, requires such premiums to be reflected in the pricing of copyrighted content generally. Moreover, the chilling costs of uncertainty may also settle (although with more questionable practical effect) ${ }^{27}$ on certain users of copyrighted works, who cannot be sure of the applicable rules governing their conduct in the inherently international environment of the world wide web.

Third, the developed world possesses a comparative advantage in the production of intellectual goods. ${ }^{28}$ That is, the trade significance of copyright industries has encouraged the developed world to address copyright law as a matter of international relations. ${ }^{29}$ If free

copyright owners. For example, although recording companies are working to facilitate the online distribution of sound recordings (with appropriate technological protections), this is, in large part, a response to the widespread availability of unauthorized recordings in MIP3 format. See Frank Rich, Stephen King's Week of Terror, N.Y. TIMES, Mar. 25, 2000, at Al9 (describing the response of record labels to the Napster software that facilitates the identification and downloading of files in MP3 format).

${ }^{2}$ See Jack L. Goldsmith, Against Cyberanarchy, 65 U. CHI. L. REV. 1199, 1217 (1998) (noting that, for almost all users, there will be no threat of extraterritorial legal liability because their lack of physical presence or assets in those jurisdictions precludes effective enforcement). Of course, users may still experience the effects of such uncertainty indirectly via related cyberactors (such as their internet service providers) who have such a presence or assets and whose conduct (and prices) will be affected by the uncertainty of applicable laws.

"x The extent to which this advantage will hold up in the digital economy is not entirely clear. While a digital divide clearly still exists both domestically and internationally, there is some evidence that the developing world is "catching up" in the development of internet technologies at a rate that would not have been conceivable in the offline context. See Charles Clark, Net Law: A Cyberspace Agenda for Publishers, $3 \mathrm{~J}$. WORLD INTELL. PROP. 97, 97 (2000) (suggesting that "China will become one of the world's largest internet markets by as early as 2003"); Thomas Crampton, Internet Expected to Offer Big Boost to Developing Nations, INT'L HERALD TRIB., Feb. 24, 2000, Special Report, at 24 (suggesting that new technologies will enable developing countries to "leap frog" over several stages of economic infrastructure development, an area in which developing countries have traditionally been disadvantaged). Copyright has always, in theory, been a more egalitarian system of property. We each (subject to uneven, but not determinative, conditions of health and education) possess the tools of copyright production. But this may be particularly true with respect to internet technologies, where manufacturing facilities are relatively unimportant to the creation of intellectual products. Cf. Romesh Ratnesar \& Joel Stein, Everyome's a Star.com, TIME, Mar. 27, 2000, at 70 (noting effects of the internet on development and distribution of entertainment products by uncapitalized individuals); Rich, supra note 26 (suggesting that the ease of production and distribution of content on the internet is "a prescription either for the greatest democratization of the arts in the history ... or a dumbing down that may make the advent of public-access cable TV look in retrospect like the Renaissance").

* See Reichman, supra note 8, at 346 (explaining that the impulse of the developed world toward the adoption of enforceable international standards reflected "the growing capacity of manufacturers in developing countries to penetrate distant markets for 
trade is understood solely in terms of an ability to exploit comparative advantage, the failure of other nations to protect intellectual property can be rationalized as an intrusion upon free trade. ${ }^{30}$

The degree to which international considerations now affect domestic U.S. copyright law is perhaps most graphically demonstrated by the brief filed by the federal government in the recent challenge to the constitutionality of the Sonny Bono Copyright Term Extension Act in Eldred Press v. Reno. ${ }^{31}$ The government argued that the domestic constitutional purpose of promoting the progress of science and the useful arts was rationally furthered by the grant of twenty extra years of copyright protection to existing works because, inter alia, such a rule ensured greater harmonization with the laws of the European Union (the "EU"). ${ }^{32}$ Although the Eldred Press court upheld the statute without reaching that argument, that it was advanced by the gov-

traditional industrial products," thus forcing "the developed countries to rely more heavily on their comparative advantages in the production of intellectual goods than in the past").

${ }^{30}$ See J.H. Reichman, Intellectual Property in International Trade: Opportunities and Risks of the GATT Connection, 22 VAND. J. TRANSNAT'L L. 747, 757 (1989) (explaining the comparative advantage argument); see also Adrian Otten \& Hannu Wager, Compliance with TRIPS: The Emerging World View, 29 VAND. J. TRANSNAT'L L. 391, 393 (1996) (noting that the stated premise of the incorporation of intellectual property protection within the GATT mechanism was that a failure to protect intellectual property of foreigners amounted to a trade barrier). Some scholars have expressed the purpose of the TRIPS Agreement in language more suggestive of exploitation by the developed world. See Ruth L. Gana, Has Creativity Died in the Third World? Some Implications of the Internationalization of Intellectual Property, 24 DENV. J. INT'L L. \& POL'Y 109, 140-41 (1995) (arguing that "the chief aim of the agreement is to secure from [developing] countries and societies the full monopoly benefits that western intellectual property laws offer"). Interestingly, however, while the accession of the developing world to the TRIPS Agreement may indeed have been significantly influenced by reciprocal trade benefits of immense social and economic importance to those countries, many of the first ratifications of the WIPO Copyright Treaty have been by developing countries. See Actions in Respect of Treaties Administered by WIPO Not Yet in Force, at http://www.wipo.org/eng/ratific/doc/u-page30.doc (July 15, 2000) (listing nations that have ratified the WIPO copyright treaty). Yet, these ratifications have not been made upon pain of trade penalty. It may be that, as suggested above, an increasing number of developing countries have been persuaded of the internal (as opposed to external trade) benefits of copyright protection in the digital age. See supra note 28.

${ }^{31} 74$ F. Supp. 2d 1, 3 (D.D.C. 1999) (upholding the constitutionality of the statute). The Sonny Bono Copyright Term Extension Act extended the term of copyright for twenty years both prospectively and with respect to existing works. Sonny Bono Copyright Term Extension Act, Pub. L. No. 105-298, 112 Stat. 2827 (1998). The constitutional challenge focuses on the extension of protection for existing works.

${ }^{32}$ Defendant's Memorandum in Support of Motion for Judgment on the Pleadings, Eldred Press (No. 99-0065), available at http://cyber.law.harvard.edu/ eldredvreno/jop_memo.html (last modified July 7, 1999). 
ernment emphasizes a salient point: internationalization is an integral component of U.S. copyright lawmaking.

\section{B. Technology}

In addition to international considerations, other forces play significant roles in the formation of contemporary copyright law. In particular, the content of copyright law is necessarily hostage to technological developments, as to some extent it always has been. ${ }^{33}$ Just as printing by movable type spurred the first copyright-like law in England in the sixteenth century, ${ }^{3 *}$ and just as copyright legislation in recent decades has tackled questions raised by the photocopier, satellite television, the home video recorder, digital audiotape, and computer software, so too copyright law is now heavily driven by the need to address the new digital environment of the internet. To which traditional copyright concepts, if any, can we analogize browsing, linking, framing, downloading, webcasting, or even forwarding of e-mail messages?

The rapidity of current technological change, promoted in particular by widespread popular use of the internet, requires a copyright lawmaking process receptive to constant adaptation. Much recent lawmaking in the United States ${ }^{35}$ and the most recent international copyright negotiations ${ }^{36}$ reflect the need for copyright law to address

"See Sony Corp. v. Universal City Studios, 464 U.S. 417, 430 (1984) ("From its beginning, the law of copyright has developed in response to significant changes in technology."); Hon. Marybeth Peters, The Spring 1996 Horace S. Manges Lecture: The National Information Infrastructure: A Copyright Office Perspective, 20 COLUM.-VLA J.L. \& ARTS 341, 341 (1996) (noting the role of technological advances in the historical development of copyright law).

See HARRY RANSOM, THE FIRST COPYRIGHT STATUTE 17-53 (1956) (discussing the role of The Stationers' Company in giving "quasi-legal status to literary property" in England during the period from 1559 to 1601 ).

See, e.g., Digital Millennium Copyright Act, Pub. L. No. 105-304, 112 Stat. 2860, 2863-64 (1998) (enacting various reforms, including a prohibition against the circumvention of technological copyright protection systems); see also WHITE PAPER, supra note 1 (discussing the reforms necessary to adapt copyright law to the digital age). Federal database legislation has been pending since 1996 and remains before Congress. See Collections of Information Antipiracy Act, H.R. 354, 106th Cong. \$ 2 (1999) (prohibiting unauthorized extraction of a substantial part of certain collections of information).

Sti See, e.g., World Intellectual Property Organization Copyright Treaty, Dec. 20, 1996, art. 11, 36 I.L.M. 65, 71 [hereinafter WIPO Copyright Treaty] (clarifying the basic principles of copyright law in light of technological developments and, inter alia, requiring signatory states to enact protection for authors against the circumvention of technological measures designed either to restrict access to works or to protect works 
challenging issues presented by new technological innovation. While legislative consideration of these issues has been bitterly contested and drawn-out, the courts in the interim have developed solutions based upon the underlying principles of copyright law. ${ }^{37}$

It is not new, of course, that the enactment of copyright legislation takes time; the last comprehensive revision of U.S. copyright law, resulting in the Copyright Revision Act of 1976, can fairly be described as a twenty-year process. But the need for the legislative process to be more responsive to technological developments has arguably increased, thus magnifying the gap between the ideal and the real. ${ }^{38}$ It is a continuing challenge for copyright law to keep pace with the technology that assists in the production, distribution, and use of the works whose creation it encourages. ${ }^{39}$ And it is a recurring question,

against copying); Basic Proposal for the Substantive Provisions of the Treaty on Intellectual Property in Respect of Databases to Be Considered by the Diplomatic Conference, WIPO Doc. CRNR/DC/6 (Aug. 30, 1996) (proposing sui generis protection for compilations of information), at http://www.wipo.org/eng/diplconf/6dc_all.htm.

${ }^{37}$ For example, the courts were in the process of developing principles under which service providers might be held liable for the transmission of infringing material by third parties using their services. See, e.g., Religious Tech. Ctr. v. Netcom On-Line Communication Servs., 907 F. Supp. 1361, 1372-73 (N.D. Cal. 1995) (holding that passive transmission of infringing material created and sent by others does not give rise to liability absent proof that once notified of the transmission, the service provider refused to remove it from the server, in which case contributory liability might attach); see also Jane C. Ginsburg, Putting Cars on the "Information Superhighway": Authors, Exploiters, and Copyright in Cyberspace, 95 ColuM. L. REV. 1466, 1492-94 (1995) (discussing various decisions addressing the copyright liability of internet service providers). The Digital Millennium Copyright Act, enacted in 1998 after four years of intense negotiation, now provides certain safe harbors for service providers, see 17 U.S.C. $\$ 512$ (Supp. IV 1998), but the same issues are likely to be relitigated under general copyright principles if a service provider fails to comply with the many detailed conditions required to avail itself of the safe harbors.

${ }^{88}$ Although the length of time that it takes to legislate copyright law is not merely a function of the technological nature of an issue, the goal of rapid lawmaking is not furthered by the fact that new technologies have brought new players into the legislative process. Not only does this make compromise more difficult, but it also introduces personnel with accumulated experience in laws quite different from copyright. Media consolidation and technological change have brought the likes of telephone companies, for example, into copyright legislative deliberation, which introduces a group more used to extensive and detailed regulation than reliance on judicially implemented general standards.

${ }^{39}$ Others have cautioned against precipitous reform of copyright law in response to the technology of the day. See, e.g., David Nimmer, Aus Der Neuen Welt, 93 Nw. U. L. REv. 195, 212-13 (1998) (suggesting caution in revising copyright law in a hasty manner to reflect current technological developments). I do not take issue with the concern about premature articulation of a legislative scheme that is immediately overtaken by technological events. Such calls for caution speak more forcefully in the legislative context, since the legislature acting alone is profoundly unsuited to the task of mapping copyright law to the daily cascade of new technological issues. But if the legisla- 
not peculiar to copyright, but particularly acute in this context, whether courts or legislatures-or what mix of the two-can best produce law that competently accommodates such technological change. Moreover, it is a question to which a different answer might be given, or to which the answer might come with more or less ease, when the choice between legislative and judicial lawmakers is moved to an international plane. ${ }^{40}$

ture actively co-opts the courts in the enterprise, by establishing a scheme with sufficient flexibility to permit courts to deal creatively with the technological copyright issues du jour, participants in the affected industries and communities can be furnished prospective guidance without fossilizing copyright law. This makes improvident recent congressional efforts to micromanage the copyright industries through extensive, detailed legislation. For a suggestion of the causes of the detailed legislative scheme, see supra note 38.

4" Some scholars have, not surprisingly, detected substantive copyright policy preferences behind debates regarding the preference for courts or legislatures. For example, Jerry Reichman and Pam Samuelson have suggested that, with regard to recent debates on the wisdom of federal database legislation:

[i]f one believes that the federal courts can apply existing copyright law to the new technologies with relatively little friction, then one has implicitly opted for a wait-and-see approach or at least for a minimalist approach, based on case-by-case judicial decisions and a minimum amount of tinkering with the statute as it stands.... This approach leaves the traditional exemptions for scientific and educational users intact, but subject to case-by-case evaluation. If, in contrast, one believes that gaps in the law leave online publishers too much at risk, then proposals for statutory reform easily escalate into a campaign to rid the emerging information infrastructure of allegedly anachronistic vestiges of the cultural bargain that had heretofore protected users and second comers of works in print and other media.

Reichman \& Samuelson, supra note 25, at $111 \mathrm{n} .275$; see also Robert C. Denicola, Some Thoughts on the Dynamics of Federal Trademark Legislation and the Trademark Dilution Act of 1995, LAW \& CONTEMCP. PROBS., Spring 1996, at 75, 80 (noting that, with respect to the development of domestic trademark law, U.S. courts have proven to be more hospitable places than legislatures in which to achieve balanced intellectual property rights). A preference for lower protection is not an intrinsic characteristic of judicial lawmaking, however, nor do I understand Reichman and Samuelson to suggest otherwise. See Graeme B. Dinwoodie, The Death of Ontology: A Teleological Approach to Trademark Law, 84 IOWA L. REV. 611,739 (1999) (noting the judicial tendency to protect against freeriding by favoring "an originator over an imitator"). And other variables may affect one's preference. For example, one might have, for any number of reasons, a preference for constructing an approach based upon articulated standards rather than rules, which may tend to shift institutional power to dispute resolution tribunals rather than legislators or treaty drafters. More important than any particular point of debate, however, is the basic proposition that the international context may alter the analysis. Joel Trachtman has noted, for example, that "in the trade context ... treaty-making would be subjected to intense domestic scrutiny while application of a standard by a dispute resolution process would be subjected to reduced scrutiny." Joel P. Trachtman, The Domain of ITO Dispute Resolution, 40 HARV. INT'L L.J. 333, 352 (1999) (citing Kenneth W. Abbott \& Duncan Snidal, Why States Act Through Formal International Organizations, 42 J. CONFLICT RESOL. 3 (1998)). Accepting Trachtman's analysis, which an unfavorable WTO decision in an election year might severely test, see generally, e.g., 


\section{The Reach of Copyright Law}

The range of stakeholders for whom copyright law has direct and immediate importance has significantly increased both in number and variety over the last few years. ${ }^{41}$ The first U.S. copyright law accorded protection only to "maps, charts and books." ${ }^{42}$ From this beginning, copyright protection has gradually been conferred on an everexpanding list of works. As copyright protection has regulated the products of an increasing number of industries, however, crafting legislation that reflects the idiosyncracies of those disparate industries has become more challenging. And it has not been a task to which Congress has readily assigned political priority; historically, the United States was a net copyright importer, and because for many years it remained outside the principal international copyright agreement, it exercised only minimal power internationally. ${ }^{43}$ In this climate, the influence of the Copyright Office and the affected copyright industries was great. Indeed, a decade ago, the U.S. Supreme Court commented that the 1976 Copyright Act, "which almost completely revised existing copyright law, was the product of two decades of negotiation by representatives of creators and copyright-using industries, supervised by the Copyright Office and, to a lesser extent, by Congress."*

United States-Tax Treatment for "Foreign Sales Corporations," WT/DS108/AB/R (Feb. 24, 2000) (holding that certain U.S. tax laws were inconsistent with the obligations of the United States under the Agreement on Agriculture), at http://www.wto.org, it is doubtful that domestic court decisions would receive a similar pass. Domestic judicial opinions, other than those grounded in the Constitution, do not provide the same political cover for domestically unpopular (perhaps overly internationalist) policies. See infra text accompanying note 107 (discussing political cover of WTO dispute settlement decisions).

${ }_{41}$ See DIGITAL DILEMMA, supra note 2, at 51 (noting the diversity of stakeholders affected by the "growing use of the information infrastructure").

42 See Copyright Act of May 31, 1790, ch. 15, 1 Stat. 124 (repealed 1802).

43 Although the United States joined the premier international copyright arrangement (the Berne Convention) in 1988, it has, since 1954, been a member of the less significant Universal Copyright Convention. See Universal Copyright Convention, opened for signature Sept. 6, 1952, 6 U.S.T. 2731, 216 U.N.T.S. 132, revised by 25 U.S.T. 1341, 943 U.N.T.S. 193 (1971). The Universal Copyright Convention established a system structurally not unlike the Berne Convention, namely, national treatment plus substantive minimum standards. See Ringer, supra note 3, at 1061-62 (describing the significant provisions of the UCC); see also infra text accompanying notes 57-60 (discussing structure of the Berne Convention).

${ }^{44}$ Cmty. for Creative Non-Violence v. Reid, 490 U.S. 730, 743 (1989); see also Jessica D. Litman, Copyright, Compromise, and Legislative History, 72 CORNELL L. REV. 857, 860-61 (1987) ("[M] ost of the statutory language was not drafted by members of Congress or their staffs at all. Instead, the language evolved through a process of negotiation among authors, publishers, and other parties with economic interests in the property rights the statute defines."); Jessica Litman, Copyright Legislation and Technological 
Yet, a quarter century later, the notion that copyright policy might be settled by traditional interindustry negotiation without excluding the perspectives of a significant number of interested parties is fanciful, to cast it in the most generous light. Copyright is now omnipresent. Since the 1976 Act, which itself regulated a wide range of different works, ${ }^{45}$ the protected categories have been extended yet further to include, for example, computer software and the architectural designs of buildings. ${ }^{46}$ There is little that a citizen can do today that does not affect, or is not affected by, a copyright-protected product. ${ }^{* 7} \mathrm{Al}-$ lied to this, copyright affects a wide array of new industries (many of which do not yet understand this). ${ }^{48}$ The digital economy is founded on industries invested in, and more crucially dependent upon, protection for intangible information-based products. And in the digital age the delivery of a book could implicate, for example, not only the publisher, but also the telephone companies whose facilities are used to distribute the work ${ }^{49}$ (and incidentally copy the work, unlike the deliv-

Change, 68 OR. L. REV. 275, 311-17 (1989) (describing the role of industry representatives and the absence of similar representatives of the public in the creation of the 1976 Copyright Act).

See 17 U.S.C. $\$ 102$ (a) (1994) (according protection generally to "original works of authorship fixed in any tangible medium of expression," and providing a diverse illustrative list of works of authorship). Since 1994, quasi-copyright protection has been extended further to live musical performances not fixed in any tangible medium of expression. See 17 U.S.C. $\$ 1101$ (1994) (codifying reforms introduced by the Uruguay Round Agreements Act of 1994).

* See Act of Dec. 12, 1980, Pub. L. No. 96-517, 94 Stat. 3028 (1980) (codified as amended at 17 U.S.C. $\$ 101$ (1994)) (expressly providing for copyright protection for computer software); Architectural Works Copyright Protection Act, Pub. L. No. 101650,104 Stat. 5133 (1990) (codified as amended at 17 U.S.C. $\$ \$ 101-102$ (1994)) (defining "architectural work" and expressly providing for its protection under copyright law).

See Jessica Litman, The Exclusive Right to Read, 13 CARDOzo ARTs \& ENT. L.J. 29, 34 (1994) (commenting that modern copyright law "touches everyone and everything").

For example, a business that wants to engage in secure digital commerce may confront questions regarding the extent to which it wants to use, and to protect the integrity of, technological measures to regulate access to the works it distributes. These questions cannot be addressed without consideration of recent provisions contained in the Digital Millennium Copyright Act. See I7 U.S.C. \$ 1201 (Supp. IV 1998) (prohibiting circumvention of technological measures that restrict access to copyrighted works).

4: Online delivery of commercially attractive novels may not be far away. Stephen King recently distributed his latest novella, Riding The Bullet, exclusively via the internet. See Rich, supra note 26 (discussing the cultural implications of King's distribution). Although technical constraints may limit the widespread use of internet delivery for full-length novels or other copyrighted works that occupy huge digital files, see id. (noting that the distribution of the King novella caused the web sites of net booksellers to crash), these constraints are likely to become less significant in the near future. At 
ery company that used to distribute books)..$^{50}$

Finally, recent developments have caused copyright law to intrude more directly into the personal and private affairs of citizens. ${ }^{51}$ At the time of the 1976 Act, the public obtained access to copyrighted works such as books, newspapers, motion pictures, or television shows, largely on terms that could be dictated by the copyright industries or their distributors. To regulate the dealings in and control of such works, Congress needed simply to address the conduct of those persons. The public could do little to interfere with the practices of the copyright industries. The availability of home copying devices and digital access to (as well as delivery of) copyrighted works transformed this arrangement. Users are now in a position to copy and deal in copyrighted material. To regulate the control of copyrighted works, ${ }^{52}$ Congress therefore must now seek to regulate the public in a far more direct fashion. ${ }^{53}$

that point, the only remaining resistance to online delivery may be cultural rather than technological. Yet, cultural habits have already been reconfigured by online delivery of sound recordings, and it may be that consumers, especially those weened on online delivery of products, will more readily cast off the attachment to physical copies of works than we assume. See Jane C. Ginsburg, From Having Copies to Experiencing Works: The Development of Access Rights in U.S. Copyright Law, in U.S. INTELLECTUAL PROPERTY: LAW AND POLICY (Hugh Hansen ed., forthcoming 2000) (manuscript on file with author) (discussing how U.S. copyright law has responded to distribution patterns that place less significance on the material "copy" of a work).

${ }^{50}$ The U.S. courts have adopted a very low threshold for what amounts to reproduction for the purpose of the Copyright Act. See, e.g., MAI Sys. Corp. v. Peak Computer, Inc., 991 F.2d 511, 517-18 (9th Cir. 1993) (holding that loading a work into the random access memory of a computer constitutes reproduction).

${ }^{51}$ See Amy Waldman, Policing Cyber Music, N.Y. TIMES, Mar. 12, 2000, at WK2 (suggesting that if the pending lawsuit filed by the recording industry against the distributors of the Napster computer program, which enables users to find and download unauthorized sound recordings in MP3 format, is ultimately unsuccessful, "the music industry may have to sue the college students who are Napster's most avid users").

${ }_{52}$ To the extent that Congress may wish to regulate extraterritorial conduct with local effects in the United States because, for example, the extraterritorial actors are not subject to the jurisdiction of the U.S. courts, it may be required to focus more on end-users. See Goldsmith, supra note 25 , at $481-83$ (discussing ways in which nations may regulate local effects of foreign conduct).

${ }_{53}$ Some scholars have suggested that the right to control access to a work that is effectively vested in copyright owners by the Digital Millennium Copyright Act, see 17 U.S.C. \$1201 (Supp. IV 1998) ("No person shall circumvent a technological measure that effectively controls access to a work protected under this title."), may become central to the ability of authors effectively to secure rights in their works in the digital age. See Ginsburg, supra note 49 (manuscript at 10) (noting that "[a]ccess controls make it possible for authors to offer end-users a variety of distinctly-priced options for enjoyment of copyrighted works"). See generally David Nimmer, A Riff on Fair Use in the Digital Millennium Copyright Act, 148 U. PA. L. REv. 673, 684-92 (2000) (discussing the anticircumvention provisions of the Digital Millennium Copyright Act). In such an envi- 
The effect of these changes on the legislative process is not yet fully clear, and indeed may continually evolve. But recent legislative battles suggest that any negotiated compromise will necessarily include a far broader range of industries, which makes agreement more difficult to reach. It may also change the nature of copyright legislation, as industries accustomed to micro-regulation resist traditional copyright reliance on broadly worded judicial standards in favor of detailed statutory provision. The recently enacted Digital Millennium Copyright Act, intended primarily to implement two treaties and to address the copyright liability of internet service providers, increased the size of the Copyright Act by one third. On the other hand, as copyright becomes more central to the lives of voters, and more crucial to the trade balance of the United States, one would expect greater political oversight by Congress. In short, the lawmaking process must now accommodate a greater range of different perspectives, even if the effect that this will have on the nature and substance of copyright law is far from clear.

\section{Public INTERNATIONAL COPYRIGHT LAWMAKING}

If some degree of international copyright lawmaking is desirable and/or inevitable, the question that next confronts us is how best to internationalize copyright law. In answering that question, each of the competing demands noted above-dynamic lawmaking, national autonomy, and pluralistic perspective-must be borne in mind. The looming presence of globalization as the dominant social and economic force of our time may tend to obscure and minimize other considerations. But if those competing considerations seem irreconcil-

ronment, copyright law directly controls the private activities of the individual user because those activities now determine the ability of the author to control the exploitation of her work. The Digital Millennium Copyright Act thus puts in place a set of rights and exceptions designed to delineate what the user sitting at her computer terminal can do to circumvent technological measures restricting access to the work. See 17 U.S.C. $\$ 1201$ (setting the scope of permissible unauthorized circumvention). It may' be, however, that the effectiveness of this balance of rights and exceptions will be determined as much by the prohibition on the sale of devices designed to facilitate circumvention of access controls (to which the privileges granted the user are not extended), and by the willingness of courts to develop a roving exception to the access right analogous to fair use in the traditional copyright context. See Ginsburg, supra note 49 (manuscript at 15) (discussing the role of a "fair access" exception in ensuring a proper balance between copyright owners and users in the digital environment). But tf. Universal City Studios, Inc. v. Reimerdes, 111 F. Supp. 2d 294, 322 (S.D.N.Y. 2000) (restricting fair use defense to an action for copyright infringement proper rather than action for violation of section 1201 anti-circumvention provisions); Universal City Studios, Inc. v. Reimerdes, 82 F. Supp. 2d 211, 219 (S.D.N.Y. 2000) (same). 
able with international copyright lawmaking, we may need to reconsider the depth of our commitment to internationalization as a driving force in the formation of copyright law. Before reaching that issue, however, in this Part, I explore changes in the primary means by which international copyright norms have been developed heretofore, namely, through state-to-state negotiation of international agreements.

\section{A. The Classical Model}

The Berne Convention, concluded in 1886, represented an effort by several copyright-respecting nations, prompted by the growing international market in books, to construct a mechanism for the protection of their citizens' works abroad. ${ }^{54}$ But the classical model of public international copyright lawmaking that the Convention established, and which it has come to epitomize, intruded only marginally on the autonomy of signatory states to establish national copyright policy. At the time of the first intergovernmental meeting in 1883 to form the Berne Union, attempts were made, particularly by the German delegation, to institute an internationally uniform system of copyright that would apply in each member state. ${ }^{55}$ Proponents of this universalist vision were rebuffed, however, because of the substantial changes to national laws that would have been required to implement such a scheme. $^{56}$

Instead, pragmatism prevailed, and the Convention embodied a two-pronged approach to international copyright law. ${ }^{57}$ First, the participating countries agreed that their national laws would adhere to a cluster of minimum substantive standards. For example, the Convention).

${ }^{54}$ See RICKETSON, supra note 15, at 19-21 (discussing motivations for the Conven-

See Jane C. Ginsburg, The Role of National Copyright in an Era of International Copyright Norms 3-4 (Sept. 9, 1999) (unpublished draft, on file with the University of Pennsylvania Law Review) (discussing the 1883 intergovernmental conference and the resolutions adopted by the three Congresses of Authors and Artists that preceded the intergovernmental conference).

${ }^{56}$ See id. at 4 (suggesting that “[a]lthough most participating countries viewed the proposition as a desirable one, they voted against it because it would have required great modifications of their domestic laws, which many countries could not implement all at once").

${ }^{57}$ Rejection of the universalist efforts also consolidated the principle of territoriality. That is, copyright laws are national in scope. An author who publishes a work in France receives protection in France according to French copyright law and receives protection in the United Kingdom separately according to the rules of U.K. copyright law. She owns a French copyright and, separately, a U.K. copyright. 
tion listed the types of works that a signatory state must protect and the minimum term of copyright protection. Signatory states could offer greater protection; they were obliged only to satisfy these minimum levels. These standards were hardly exacting. ${ }^{58}$ The less demanding the obligations, it was thought, the more countries were likely to become members of the Union and enforce basic notions of copyright. $^{39}$ The group of copyright-respecting nations, in which authors' rights were protected, would thus be enlarged. Second, and central to the Berne system, member states agreed to the obligation of national treatment. ${ }^{50}$ That is, signatory states undertook to provide authors from, or works first published in, other signatory states with protection as generous as that afforded domestic authors and works.

Although the universalists made periodic inroads into this model throughout the twentieth century in the form of serial upwards revision of the minimum standards, there remained significant latitude for signatory states to develop distinctive national copyright policies tailored to their own cultural or economic priorities. For example, countries remained free to define the "author" of a work, and thus the initial owner of the copyright, in a fashion consistent with the philosophical grounding of their copyright system either in individual personality or in instrumentalist financial incentives. ${ }^{61}$ Thus, U.S. law reflects its predominantly instrumentalist orientation by recognizing employers as authors of works prepared by employees within the scope of their employment, ${ }^{62}$ whereas French law links ownership to the personality of the individual author by treating the employee as the author in the same circumstance. ${ }^{63}$ Similarly, the Convention af-

See RICKETSON, supra note 15, at 53, 73-74 (discussing the substance of the 1886 text and drafts upon which it was based).

See id. at 73-74 (explaining the choices that were before the countries negotiating the original text).

'see Berne Convention, supra note 15, art. 5(1), 1161 U.N.T.S. at 31 ("Authors shall enjoy, in respect of works for which they are protected under this Convention, in countries of the Union other than the country of origin, the rights which their respective laws do now or may hereafter grant to their nationals ....").

"il Cf. STEWART, supra note $23, \S 4.46$ (noting latitude under the Berne Convention for national laws to determine the owner of the copyright).

"See 17 U.S.C. $\$ 201$ (b) (1994) (providing that the employer or commissioning party is the author of a work made for hire); 17 U.S.C. $\$ 101$ (1994) (defining "work made for hire" as a work prepared by an employee within the scope of his employment or certain categories of specially commissioned works where the parties agree in writing that the work is made for hire); see also Copyright, Designs and Patents Act, 1988, c.48, $\$ 11(2)$ (Eng.) (granting employers rights in works prepared by an employee within the scope of the employee's employment).

is See Law No. 92-597 of July 1, 1992 on the Intellectual Property Code, art. L-113 
forded countries generous scope to create exceptions to copyright that effectuated national attitudes to free speech or other countervailing social policies. ${ }^{64}$ For example, U.S. copyright law accords users broad latitude under the rubric of fair use to make unauthorized parodies of copyrighted works ${ }^{65}$ and provides a series of specific exceptions that permit, for example, the unauthorized public performance of a musical work at a horticultural fair ${ }^{66}$ or in face-to-face classroom instruction. ${ }^{67}$ Civil law countries tend to favor only the latter approach (so-called "closed systems"), each providing different lists of narrow exceptions tailored to its own social and economic priorities. ${ }^{\text {bN }}$ Although these different approaches inevitably privilege many similar acts-such as core educational or research uses, or uses implicating free speech concerns-many also reflect the exigencies of national cultural policy (or political demands) ${ }^{69}$

The process of public international copyright lawmaking tended to be slow and unwieldy because it operated by way of consensus among, ultimately, ${ }^{70}$ countries with a diverse range of social and eco-

(amended Mar. 27, 1997) (Fr.) (providing for copyright ownership by employers only with respect to software).

${ }^{64}$ See Shira Perlmutter, Future Directions in International Copyright, 16 CARDOZO ARTS \& ENT. L.J. 369, 370 (1998) (noting that "[m] ore variety exists in delineating the precise scope of rights through exceptions and limitations, although certain general categories are common"); Sam Ricketson, The Boundaries of Copyright: Its Proper Limitations and Exceptions: International Conventions and Treaties, 1999 INTELL. PROP. Q. 56, 93 (1999) (noting the flexibility given to national legislators by international treaty provisions on exceptions and limitations); Ginsburg, supra note 55, at 14-15 (discussing latitude for exceptions).

${ }^{65}$ See Campbell v. Acuff-Rose Music, Inc., 510 U.S. 569, 594 (1994) (holding that a rap music group's commercial parody was a transformative use favorably regarded under the fair use doctrine).

${ }^{66}$ See 17 U.S.C. $\$ 110(6)$ (Supp. IV 1998) (providing that such performances do not give rise to copyright liability for infringement of the copyright owner's exclusive right of public performance).

${ }^{67}$ See id. $\$ 110(1)$ (providing that such performances do not give rise to copyright liability for infringement of the copyright owner's exclusive right of public performance).

${ }^{68}$ For example, Italy provides an exception permitting military musical groups and bands to play copyrighted music in public without paying compensation to the owner of the copyright in the musical work. See Law No. 633 of Apr. 22, 1941, Gazz. Uff., art. 71 (amended July 29, 1981), translated in COPYRIGHT LAWS AND TREATIES OF THE WORLD (Supp. 1987-1988) (Italy).

${ }^{69}$ For a discussion of the different exceptions found in national laws, see Jaap $\mathrm{H}$. Spoor, General Aspects of Exceptions and Limitations to Copyright: General Report, in THE BOUNDARIES OF COPXRIGHT 27 (Libby Baulch et al. eds., 1999).

${ }^{70}$ The majority of the twelve participants at the 1886 convention were European and thus reflected less diversity than is now the case. See RICKETSON, supra note 15, at 79 (listing the countries participating in the negotiation of the 1886 convention). By 
nomic perspectives. Those agreements that it produced were, in large part, codifications of commonly held, and already nationally implemented, copyright policies, ${ }^{71}$ and thus had a backward-looking perspective. $^{72}$ They constituted the received wisdom of the participating countries, rather than prospective solutions to new problems. This relationship between national and international lawmaking is perhaps best exemplified by the approach of the United States in 1908 when, although not yet a party to the Berne Convention, it

was invited to attend [the revision conference] with "full freedom of action," but the delegate, Thorvald Solberg, the Register of Copyrights, was sent as an observer only. Mr. Solberg explained to the Conference that the United States found it impracticable to send a delegate authorized to commit it to actual adhesion to the Berne Convention since some of the questions to be discussed there were pending before the Congress and premature action at the Convention might embarrass the legislative branch of the Government. $^{78}$

Similarly, as noted above, the rejection of the universalist position at the 1883 intergovernmental conference was based in large part upon the significant modification of domestic laws that the adoption of a universalist approach would have mandated. ${ }^{74}$

the time TRIPS was concluded in 1994, however, the Berne Convention had been revised five times, and 130 countries from around the world had joined. See Berne Convention for the Protection of Literary and Artistic Works, at http://www.wipo.org/ eng/ratific/doc/e-bern.doc (listing current Berne ratifications).

${ }^{71}$ Some degree of compromise has been achieved over the years. See STEWART, supra note $23, \$ 1.16$, at $9-10$ (noting the compromises between civil law states adhering to a system of droit d'auteur and common law countries following a copyright approach to authors' rights); Davies, supra note 1, at 965 (noting that the Berne Convention had "provided a bridge" between the systems of copyright found in common law countries and the droit d'auteur systems of civil law countries); $c f$. Jane C. Ginsburg, A Tale of Two Copyrights: Literay Property in Revolutionary France and America, in OF AUTHORS AND ORIGINS: ESSAYS IN COPYRIGHT LAW 131 (Brad Sherman \& Alain Strowel eds., 1994) (suggesting greater congruity between U.S. and French literary property regimes than conventionally understood). The most significant advances requiring changes in national legislation occurred at the Berlin revision conference of 1908. See RICKETSON, supra note 15, at 96 (calling the Berlin Act a "significant advance towards an international copyright codification").

${ }^{72}$ This is not invariable. Some provisions of the Berne Convention are intentionally receptive to changing circumstances and are cast in language that admits of evolution over time. For example, Article 9(2), governing permissible exceptions to certain rights of the copyright owner, includes concepts such as "normal exploitation of a work" that appear consciously designed to change with and reflect the times. Neil W. Netanel, The Next Round: The Impact of the IVTPO Copyright Treaty on TRIPS Dispute Settlement, 37 VA. J. INT'L L. 441, 470 (1997).

Ringer, supra note 3, at 1057 .

${ }^{74}$ See Ginsburg, supra note 3, at 268-69 (explaining why the 1883 and 1885 Conferences did not adopt a "comprehensive and universal copyright law"). 
This perspective was ensured not only by the rather deliberate nature of multiparty, international diplomacy and the consensual modus operandi, but also by exclusive reliance on the quasi-legislative process of treaty revision as a means of updating the Convention. Although later versions of the Convention permitted the referral of disputes regarding compliance with the Convention to the International Court of Justice $^{75}$ this mechanism was never used. ${ }^{76}$ Authoritative contemporary interpretation of the Convention and its application to new issues thus never occurred outside the slow-moving process of multiparty treaty revision. ${ }^{77}$

Yet, as noted above, technological pressures demand a rapidity of lawmaking, a dynamic disposition, and a forward-looking perspective. Thus, while globalization suggests a need for international lawmaking, the classical model hardly seems appropriate for such fast changing climates.

\section{B. The New Model}

If the classical model of public international lawmaking did not effectively reconcile these different demands, one strategy would be to alter the nature of the public international lawmaking process. I argue that this has already happened, and in this part of the Article I will discuss the changes that lead me to that conclusion. In Part II.C, I will further suggest why these changes are insufficient in themselves to address the diverse exigencies of copyright lawmaking. Throughout this discussion I focus in particular on three aspects of the new public

${ }^{75}$ See Berne Convention, supra note 15 , art. 33, 1161 U.N.T.S. at 50 (establishing the jurisdiction of the International Court of Justice).

${ }^{76}$ Moreover, no "state invoked the doctrine of retaliation and retorsion theoretically available under international law for violation of international minimum standards of intellectual property protection." J.H. Reichman, Enforcing the Enforcement Procedures of the TRIPS Agreement, 37 VA. J. INT'L L. 335, 339 n.17 (1997).

77 There are records of the deliberations at diplomatic conferences resulting in the conventions, but these reveal only static meaning. And although the WIPO and national authorities periodically have expressed their views on the meaning of the conventions, no centralized source, let alone one that was effectively binding, offered contemporary interpretations. The WIPO has no authority to issue official interpretations of the conventions that it administers. See William R. Cornish, Genevan Bootstraps, 19 EUR. INTELl. PROP. REv. 336 (1997) (criticizing the WIPO for issuing reports and comments on model laws that purport to offer interpretations of international conventions).

${ }^{78}$ See J.H. Reichman, The Know-How Gap in the TRIPS Agreement: Why Software Fared Badly, and What Are the Solutions, I7 HASTINGS COMM. \& ENT. L.J. 763, 765 (1995) (noting that "both the strengths and weaknesses of the TRIPS Agreement stem from its essentially backwards-looking character"). 
international model: efforts to enable international institutions to react more quickly to new developments without the need for diplomatic conferences or complete consensus; a less unidirectional relationship between national and international lawmaking, resulting in an essentially integrated and more forward-looking lawmaking process; and the adoption of an effective dispute settlement system among states to ensure compliance with internationally agreed-upon standards. This final aspect of the new model will receive particular attention in Part II.C.

The primary institutional actor in the classical public international model was the World Intellectual Property Organization ("WIPO"). Most of the major multinational intellectual property agreements establish unions consisting of all states that have adhered to the treaty in question. The unions assist in the review and revision of existing agreements. Although the unions are governed by assemblies of the adherent countries, the WIPO was (and remains) the administrator of most major unions and treaties and is thus principally responsible for the daily operations of those unions. But the limits of the classical model discussed above persuaded many countries, and in particular developed countries, to consider additional vehicles for international copyright lawmaking. In the late 1980 s, the EU undertook an ambitious series of legislative initiatives in the field of copyright and other intellectual property rights. These measures, ostensibly in the pursuit of harmonization of the national laws of EU member states, largely resulted in the enhancement of intellectual property rights. ${ }^{79}$ At a broader geographic level, the Uruguay Round of the GATT negotiations was expanded to include intellectual property rights, resulting in the conclusion of the TRIPS Agreement in 1994.

Both the EU initiatives and the TRIPS negotiations added new dimensions to public international copyright lawmaking. The directives $^{80}$ adopted by the EU did not require the agreement of all mem-

${ }^{79}$ See W.R. Cornish, 1996 European Community Directive on Database Protection, 21 COLUM.-VLA J.L. \& ARTS 1, 13 (1996) (noting the EU belief that "intellectual property rights should be set at the maximum which is decently achievable").

A directive is a legislative instrument of the EU (properly, the European Community ("EC")), but is not directly applicable in the member states. Its provisions normally require positive implementation in the domestic laws of the member states, although certain provisions of directives may be treated as directly creating rights in member states under the doctrine of "direct effect". See TREATY ESTABLISHING THE European COMMUNITY, Nov. 10, 1997, O.J. (C 340) 3, 278, art. 249 (1997) [hereinafter EC TREATY] ("A directive shall be binding, as to the result to be achieved, ... but shall leave to the national authorities the choice of form and methods."). See generally P.S.R.F. MLATHIJEN, A GUIDE TO EUROPEAN COMMUNITY LAW 90 (5th ed. 1993) (dis- 
ber states of the EU. ${ }^{81}$ The European Commission ${ }^{82}$ may bring (and has brought) actions before the European Court of Justice against recalcitrant states to compel implementation of the standards in the directives. ${ }^{83}$ And, although the EU directives have addressed issues (such as copyright term) upon which member states had welldeveloped policies, a number of the directives addressed issues roughly contemporaneously with the first serious national attention to the same issues. Thus, the EU has promulgated detailed directives

cussing the nature and effect of directives); 5 HANS SMIT \& PETER E. HERZOG, THE LAW OF THE EUROPEAN ECONOMIC COMMUNITY: A COMMENTARY ON THE EEC TREATY $\$ \S 189.11,189.14$ (1994). Other legislative measures resulting in the creation of unitary EU-wide intellectual property rights, rather than harmonization of national laws, do require unanimity of the member states, but these have involved industrial property rights. See Graeme B. Dinwoodie, Federalized Functionalism: The Future of Design Protection in the European Union, 24 AM. INTELL. PROP. L. ASS'N Q.J. 611, 636-37 (1996) (discussing why measures proposed pursuant to ex-Article 235-now Article 308-can become law over the objections by the European Parliament). The unitary Community Trademark is now in existence, the legislation creating the unitary Community Design Right is pending, and the European Commission recently announced proposals for the creation of a unitary Community Patent. See Council Regulation 40/94 of 20 December 1993 on the Community Trademark, 1994 O.J. (L 11) 1 (establishing the Community Trademark); Proposal for a European Parliament and Council Regulation on the Community Design, COM(93)342 final at 1 (1993) (proposing the creation of a unitary design right); Communication from the Commission to the Council, the European Parliament, and the Economic and Social Committee, Promoting Innovation through Patents, The Follow-Up to the Green Paper on the Community Patent and the Patent System in Europe (1999) (recommending the creation of an EU-wide unitary patent), at http://europa.eu.int/comm/internal_market/en/intprop/indprop/ $8682 \mathrm{en}$. pdf. These reforms have been effected through regulations. A regulation of the European Community has general application, is binding in its entirety, and is directly applicable in all member states. See EC TREATY art. 249. See generally 5 SMTT \& HERZOG, supra, at $\$ 189.09$-10. EC regulations do not require national implementing legislation to become effective in Member States. See MATHIJSEN, supra, at 89.

${ }^{81}$ See EG TREATY art. 95 (authorizing legislation to achieve approximation of laws where necessary to complete the internal market).

${ }^{82}$ The European Commission is central to the European project because it initiates all EU legislation. The Commission is based in Brussels, has twenty appointed members, two each from the five largest EU countries (France, Germany, Italy, Spain, and the United Kingdom) and one from each of the other ten member states. See id. art. 213.

${ }^{83}$ See id. art. 226 (providing that the Commission may bring action against a member state that fails to fulfill an obligation under Community law); see also CopyrightFailure to Implement Council Directive 92/100 Within Specified Time Limit, EUR. CURRENT L., Nov. 1999, at 36 (describing Commission v. Ireland, which upheld a Commission action against Ireland for failure to implement Rental Rights Directive, Council Directive $92 / 100$, and rejected the Irish defense that implementation was awaiting full-scale review of Irish copyright legislation). This action will normally be brought by the Commission, but may also be brought (under Article 227) by another member state. See EC TREATY art. 227 (providing that a member state may bring action against another member state for violation of its obligations under Community law). 
addressing copyright dilemmas such as the protection of computer programs and databases, and satellite transmission of copyrighted works. ${ }^{* 4}$ Finally, the European Court of Justice is available to interpret the directives in light of new technological developments, and thus to maintain the currency of the laws.

To be sure, this more forward-looking perspective can be traced to the different goals of the European project, namely, the eradication of differences in national laws that might impede the free flow of goods within the EU. This objective requires a willingness to address the most important types of goods currently trading within the EU, including those embodying or being carried by new technology. And harmonization of laws within the EU is different from the strategy of minimum standards pursued by the drafters of the Berne Convention. Common market-driven harmonization requires more tightly-defined obligations and necessarily intrudes to a greater extent on national sovereignty. ${ }^{85}$ It is not limited to a declaration of commonly held fundamental norms, such as the need to protect literary works against unauthorized reproduction. Finally, to lock EU member states into this more far-reaching and more urgent public law endeavor, each member state has formally ceded some of its sovereignty to a standing set of governmental institutions. Although the reasons for these differences can thus be explained, a new public international copyright dynamic has clearly been forming among EU states. It is one that appears, at least superficially, to address some of the deficiencies of the classical model.

The TRIPS Agreement is further evidence that the model of public international copyright lawmaking is changing. Although the TRIPS Agreement itself is in large part backward-looking, constructed on the Berne model of minimum standards and national treatment, ${ }^{8 \dot{6}}$

${ }^{* 4}$ See Council Directive 93/83/EEC of 27 September 1993 on the Coordination of Certain Rules Concerning Copyright and Rights Related to Copyright Applicable to Satellite Broadcasting and Cable Retransmission, 1993 O.J. (L 248) 15 [hereinafter Cable and Satellite Directive]; Database Directive, supra note 21; Council Directive 91/250/EEC of 14 May 1991 on the Legal Protection of Computer Programs, 1991 O.]. (L 122) 42 [hereinafter Software Directive].

"For a comparative discussion of harmonization efforts in the EU and the United States, see HLARMONIZATION OF LEGISLATION IN FEDERAL SXSTEMS: CONSTITUTIONAL, FEDERAL AND SUBSIDLARTTY ASPECTS-THE EUROPEAN UNION AND THE UNITED STATES OF AMERIKA [sic] COMPARED (Ingolf Pernice ed., 1996).

The approach of the TRIPS Agreement has been referred to as "Berne plus." See, e.g., Reichman, supra note 8 , at 370 (discussing the "Berne plus" formula of the TRIPS Agreement). The "plus" part of this formulation refers primarily to additional minimum standards that TRIPS added beyond those found in the Berne Convention. 
it too arose in an institutional setting more conducive to expeditious and prospective lawmaking. ${ }^{87}$ The incorporation of TRIPS within the broader institutional structure of the GATT permitted cross-sectoral concessions, and thus greater room for maneuver. And the inclusion of TRIPS within the enforcement and dispute settlement mechanisms of the WTO appears at first to mirror events unfolding within the EU because it holds out the potential (or danger) of prospective lawmaking by adjudicatory panels.

This additional activity should not, however, conceal the continuing centrality of the WIPO to the public international copyright lawmaking process. In 1995, the WIPO and the WTO entered into an agreement under which the WIPO will provide technical assistance to the WTO. ${ }^{88}$ And, in 1996, two new multilateral copyright treaties were concluded under the auspices of the WIPO. ${ }^{89}$ But the WIPO would appear to have taken on board the EU developments and TRIPS. Those treaties--the WIPO Copyright Treaty and the WIPO Performances and Phonograms Treaty-were an attempt to develop copyright law prospectively for the digital age; some dubbed the treaties the

${ }^{87}$ From the standpoint of the United States, the effort to remedy the slowness of the treaty ratification mechanism was addressed by the creation of fast-track authority (which has since expired). Both the North American Free Trade Agreement ("NAFTA") and the GATT were negotiated and their implementation legislation enacted under this authority. In Made in the USA Foundation v. United States, 56 F. Supp. 2d 1226 (N.D. Ala. 1999), a federal district court held that the NAFTA Agreement was validly enacted and that the fast-track legislative process did not unconstitutionally circumvent the Treaty Clause of the U.S. Constitution. Id. at 1317-23. The Treaty Clause gives the President the power "by and with the Advice and Consent of the Senate, to make Treaties, provided two thirds of the Senators present concur." U.S. CoNST. art. II, $\S 2, \mathrm{cl}$. 2. The fast-track procedure limits Congress's debate time, permits the House and Senate only to vote for or against the agreement in its entirety, without amendment, and enacts the agreement on the basis of simple majority votes in each chamber. The court concluded that the Treaty Clause was not the only mechanism by which an international agreement could be created and approved, citing particularly Congress's broad Commerce Clause authority and the President's authority to conduct foreign affairs. See Made in the USA Found., 56 F. Supp. 2d at 1317-23 (upholding NAFTA and the NAFTA Implementation Act as constitutional exercises of authority granted under the Omnibus Trade and Competitiveness Act of 1988).

${ }^{88}$ Agreement Between World Intellectual Property Organization and World Trade Organization, Dec. 22, 1995, 35 I.L.M. 754, 756-57 (agreeing upon the availability of WIPO resources to WTO members). The TRIPS Agreement expressly contemplated a continuing role for the WIPO, both in the context of TRIPS Council activities generally, see TRIPS Agreement art. 68, and in the periodic reviews of TRIPS implementation for which the TRIPS Council is responsible under Article 71.

${ }^{89}$ WIPO Copyright Treaty, supra note 36; WIPO Performances and Phonograms Treaty, Dec. 23, 1996, 36 I.L.M. 76. 
"WIPO Internet Treaties." More important, perhaps, this international attention to, and development of, new rules for digital copyright occurred in advance of-or simultaneously with-significant national legislative consideration of the same issues. The WIPO Copyright Treaty, in particular, looked afresh at the problems of the digital environment (for example, it contained the first rules on the circumvention of measures designed to protect copyrighted works), and it is now being implemented in national laws throughout the world. ${ }^{91}$

This last statement might suggest an inversion of the unidirectional vector that I identified as emblematic of the classical model, namely, the elevation of the national rule to an international norm. But this would be an oversimplification of the new model. To be sure, an international treaty negotiation may now represent one of the early aspects of the lawmaking process on a topic rather than an accommodation or codification of established national policies. But, so too, domestic U.S. copyright policy has cast its shadow on recent foreign and international developments. Indeed, national, regional, and international developments may have a profound influence on each other. The relationship is increasingly complex and multidirectional.

\footnotetext{
"*) Mihảly Ficsor, Copyright for the Digital Era: The WIPO "Internet" Treaties, 21 COLUM.VLA J.L. \& ARTS 197, 199 (1997).

4l In addition, the WIPO has recognized the need for more responsive international lawmaking by restructuring itself to create standing committees on a range of topics. See Report of the Director General of WPPO on Activities of the Standing Committee on the Law of Patents (SCP), the Standing Committee on the Law of Trademarks, Industrial Designs and Geographical Indications (SCT) and the Standing Committee on Information Technologies (SCIT), WIPO Doc. WO/GA/23/1 (Sept. 4, 1998) (noting the establishment of standing committees and discussing their activities). And, at least in other areas of intellectual property, the proposals of the standing committees have been adopted by member states as nonbinding resolutions of the General Assemblies of the Union in question rather than as formal treaty documents. See Standing Committee on the Law of Trademarks, Industrial Designs and Geographical Indications, Provisions on the Proteclion of Well-Known Marks, Joint Resolution Concerning Provisions on the Protection of Wellknown Marks 3, WIPO Doc. A/34/13 (Aug. 4, 1999) (“[T]his creates no legal obligation for any country, but following such a recommendation would produce practical benefits." (citations omitted)), available at http://www.wipo.int/eng/document/ govbody/wo_gb_ab/pdf/a34_13.pdf; see also Proposed Joint Resolution Concerning Provisions on the Protection of Well-Known Marks, General Report of the Assemblies of the Member States of WPO, 34th Annual Series of Meetings II 171-83, WIPO Doc. A/34/16 (Sept. 29, 1999) (reporting national interventions in the debate on the proposed solution). In essence, the WIPO is recognizing that its objectives might better be pursued by the creation of "soft law" than by conclusion of formal treaties. On the role of "soft law" in public international law, see A.E. Boyle, Some Reflections on the Relationship of Treaties and Soft Law, 48 INT'L \& COMP. L.Q. 901 (1999).
} 
A variety of instruments-formal and informal, ${ }^{92}$ national and international-can play different roles in the lawmaking process on different occasions. Copyright agendas may now be pursued simultaneously or serially in domestic and international fora. ${ }^{93}$

The allure of this new international lawmaking model, with its fluid and unpredictable interrelationship among national, regional, and international laws, may have a significant impact on national laws even where international institutions are presently silent. The content of national or regional measures adopted independently of active treaty deliberation is frequently devised with an eye to the possible development of international standards. This phenomenon takes the most direct form of reciprocity-conditioned rights, such as the database rights in the EU Database Directive and the extended term of copyright in the Term Directive, both of which prompted legislative reaction in the United States (and may yet generate international agreements). ${ }^{94}$ But, when the influence of the interrelationship be-

${ }^{92}$ Professors Reichman and Samuelson suggested, for example, in their discussion of the flurry of database protection initiatives that have arisen in the last few years, that "[i]n this climate, it is literally possible for an as yet unimplemented legislative initiative of one government to become an international minimum standard for other governments before most people affected by it ... even know that proposals for new intellectual property rights have been put on the table." Reichman \& Samuelson, supra note 25, at 76. Despite the fears expressed by Reichman and Samuelson, the database treaty proposals were tabled in 1996 and have not become an international standard, suggesting perhaps that there is sufficient international vigilance to prevent the realization of such fears.

${ }^{93}$ Reflecting the multidirectional nature of the process described above, under this dynamic, the negotiation of an international treaty containing provisions that might previously have been controversial if enacted domestically may influence later congressional consideration of the same measures. See, e.g., Samuelson, The U.S. Digital Agenda, supra note 20, at 373-74 (suggesting a relationship among the Clinton Administration White Paper, the WIPO Copyright Treaty, and the treaty implementing legislation that would have developed had early drafts of the WIPO Copyright Treaty been adopted); $c f$. Netanel, supra note 72, at $443 \mathrm{n.13}$ (noting, unfavorably, that the Clinton administration was likely to pursue in Congress an agenda upon which it had failed to secure international agreement in the negotiation of the WIPO Copyright Treaty). Netanel's observation inverts the complaint of Reichman and Samuelson, who are concerned that national governments might try to achieve internationally that which is controversial at home. See supra note 92 . Each of these criticisms ignores the reality that, in the current climate of necessary internationalization, the international and domestic processes are inevitably intertwined, and that different checks (reflecting the structures of the different institutions) apply in each setting. The interrelationship should not be troubling, although the strategic use of one merely to influence the other might have adverse consequences. See infra text accompanying note 95 (discussing the creation of "cards" for use in future negotiations).

${ }_{94}$ The reciprocity requirements are intended to prod other countries to follow suit. See Reichman \& Samuelson, supra note 25, at 97 n.201 (noting statements of EU 
tween national and international lawmaking becomes apparent, as it has to the EU and to some in the United States, it clearly affects the content even of domestic laws that lack reciprocity conditions. For example, the European Commission candidly justified recent design law reforms because of the ability of such legislation to strengthen its hand internationally. ${ }^{95}$ National laws become cards to play in forthcoming negotiations.

\section{Dispute Settlement in Public Intermational Copyright Law}

\section{The Apparent Potential of the WTO}

Despite exhibiting some characteristics of the new public international copyright lawmaking model, TRIPS is still primarily backwardlooking. ${ }^{46}$ The ordinary method of amending the TRIPS Agreement-approval of a TRIPS Council proposal by a two-thirds majority of a Ministerial Conference-is somewhat time-consuming. ${ }^{97}$ And even the expedited process contemplated by Article 71(2), whereby the TRIPS Council may by consensus vote "adjust [the agreement] to higher levels of protection of intellectual property rights achieved, and in force, in other multilateral agreements and accepted under those agreements by all members of the WTO," requires the predicate

officials with respect to the Database Directive); see also Jean-François Verstrynge, The European Commission's Direction on Copyright and Neighboring Rights: Toward the Regime of the Turenty-First Centur; 17 COLUM.-VLA J.L. \& ARTS 187, 205 (1993) (discussing the role of reciprocity in developing copyright law).

See Commission of the European Communities, Green Paper on the Legal Protection of Industrial Design, Working Document of the Services of the Commission, at I 3.5.2, Doc. No. 111/F/5131/91-EN (1991) ("Unifying the Community legislation in this field would automatically strengthen the negotiating position of the Community in the international framework."); see also Press Release of Directorate-General on Media, Information Society and Data Protection, Dec. 8, 1999 (noting that in some areas [the proposed e-commerce Directive] provides for solutions that may serve as a model at the international level, thus reinforcing Europe's influence on the development of an international legal framework").

"wi See Reichman, supra note 30, at 765 (describing the structure and orientation of the TRIPS Agreement).

${ }^{17}$ See Abbott, supra note 10, at 667-68 (describing the process of TRIPS amendment). The Council for TRIPS (or "TRIPS Council") meets at least five times a year in Geneva, and each member state of the WTO may send a representative. The Council has oversight responsibility for the TRIPS Agreement, and thus monitors the operation and implementation of the Agreement. It is in this forum that countries will first seek informally to resolve differences regarding interpretation or implementation of the Agreement. See generally Matthijs Geuze \& Hannu Wager, WTO Dispute Settlement Practice Relating to the TRIPS Agreement, 2 J. INT'L ECON. L. 347, 382-84 (1999) (describing the role of the Council for TRIPS). 
of a concluded multinational agreement. ${ }^{98}$

The TRIPS Agreement was, however, one of the agreements subsumed within the newly minted WTO dispute settlement mechanism." One of the objectives, and achievements, of the Uruguay Round of the GATT was to make proceedings that formerly took place before GATT panels more adjudicatory in nature. ${ }^{100}$ The diplomatic model of the GATT gave way to the judicial model of the WTO, reflecting an attempt to shift from a power-based to a rule-based procedure. ${ }^{101}$ On its face, the addition of WTO enforcement mechanisms would appear to permit the TRIPS system to evolve beyond the 1994 text, and thus to address in a dynamic fashion new technological issues as they arise. The WTO dispute settlement mechanism may therefore appear to complete the transformation of public international copyright lawmaking in such a way that the competing concerns identified in Part I of this Article can be accommodated.

Certainly, the switch from a diplomatic to an adjudicatory model has generated an increased level of state-to-state litigation. The number of WTO panels convened thus far outpaces the rate of resort to

${ }^{98}$ TRIPS Agreement art. 71 (2); see Abbott, supra note 10, at 668-69 (describing the expedited process). This expedited process itself reflects a substantive bias of the TRIPS system, namely that only changes in favor of higher protection are facilitated. This follows, of course, from the premise of TRIPS that distortions in trade flow occur as a result of inadequate intellectual property protection (rather than inappropriate protection, whether too much or too little). See TRIPS Agreement art. 1(1); Berne Convention, supra note 15, art. 20.

${ }^{99}$ For a superb analysis of potential issues raised by WTO adjudication of TRIPS disputes before any cases were filed, see Rochelle Cooper Dreyfuss \& Andreas F. Lowenfeld, Two Achievements of the Uruguay Round: Putting TRIPS and Dispute Settlement Together, 37 VA. J. INT'L L. 275 (1997).

${ }^{100}$ See id. at 316 (situating the existence of the Appellate Body within the preference for a judicial model of dispute settlement). For discussion of the reform of the prior GATT system effected by the change to the WTO panels under the DSU, see Kenneth Abbott, The Uruguay Round and Dispute Resolution: Building a Private Interesis System of Justice, 1992 Colum. Bus. L. REv. 111 (1992), Miquel Montañà I. Mora, A GATT with Teeth: Law Wins over Politics in the Resolution of International Trade Disputes, 31 COLUM. J. TRANSNAT'L L. 103, 128-46 (1993) (setting out changes to the dispute settlement system discussed during the Uruguay Round), and Michael K. Young, Dispute Resolution in the Uruguay Round: Lauyers Triumph over Diplomats, 29 INT'L LAW. 389, 396400 (1995) (discussing reforms of the dispute resolution mechanism).

${ }^{101}$ See Adrian T.L. Chua, Precedent and Principles of WTO Panel Jurisprudence, 16 BERKELEY J. INT'L L. 171 (1998) (describing the shift to a rule-based model of dispute settlement within the WTO); Kim Van der Borght, The Review of the WTO Understanding on Dispute Settlement: Some Reflections on the Current Debate, 14 AM. U. INT'L L. REV. 1223, 1224 (1999) (describing the ways in which the Uruguay Round changed the nature of the dispute settlement process from a power-based to a rule-based procedure). 
GATT panels prior to $1994 ;{ }^{102}$ and while sixteen cases have been filed under TRIPS in the five years since the conclusion of the WTO Agreement, no claims for violation of international intellectual property laws were brought before the International Court of Justice during the period when such recourse was available under the Berne Convention. ${ }^{103}$

\section{Resisting an Activist Interpretive Philosophy in the WTO}

The temptation to embrace an activist WTO as part of this new model of public international lawmaking should, however, be resisted, for the several reasons discussed in this Part. First, the constitutive documents of the WTO, the TRIPS Agreement, and the Dispute Settlement Understanding ("DSU") envision a more restrained judicial role. Second, despite its juridicization, the WTO dispute settlement process is, in terms of representational legitimacy, far removed and insulated from appropriate democratic pressures (both by inherent institutional place and by current rules on transparency of process). Third, that process is likely to produce norms of copyright law skewed in favor of particular values and interests: the state-initiated and intentionally trade-centered nature of the process may result in a narrower perspective of copyright issues than might otherwise be the case. Finally, the WTO dispute resolution process will generate rules of international effect that are immediately, upon first articulation, embedded as norms of a fundamental, higher level with preemptive effect on alternative generative mechanisms. This last factor has several adverse consequences. If the WTO were to assume a role in articulating idealized rules of international copyright law rather than minimum standards, the flexibility necessary to accommodate culturally and economically contingent copyright policies would be lost to the detriment of both individual countries and the international system. Moreover, it would deny the opportunity for particular national or regional institutions with varied interests to develop alternative solutions and act as laboratories for ultimately internationalized standards. The backward-looking nature of the existing public international copyright law is both a weakness and a strength. Its weakness is, as discussed above, its inability in and of itself to supply the means by

${ }^{312}$ See Chua, supra note 101 , at 172 (reporting in 1998 that "GATT dispute settlement panels resolved more than 100 cases between 1947 and 1994, [while s]ince the implementation of the DSU in 1995, the WTO has received over 100 trade disputes with 28 cases proceeding to a dispute settlement panel" (citations omitted)).

Ins See supra text accompanying notes 75-76. 
which to ensure the internationalization of copyright law. However, in adopting a backward-looking posture, the classical model of public international copyright law preserves other values equally worthy of attention.

\section{a. The Agreements Contemplate No Dynamic Lawmaking Role for WTO Panels}

The DSU, under which the panels of the WTO Dispute Settlement Body ("DSB") operate, makes clear that rulings of that body "cannot add to or diminish the rights and obligations provided in the covered agreements." ${ }^{104}$ This provision would appear to be an attempt to constrain judicial activism. If signatory states begin to file complaints in gray areas, however, particularly with the expiry of the moratorium on non-violation complaints, ${ }^{105}$ an institutional momentum could develop within the WTO to develop international copyright law. Moreover, some TRIPS provisions use broad language that we would typically describe as standards rather than rules. ${ }^{106}$ This may reflect an agreement by countries to disagree, or it may reflect a desire by the signatory nations to leave tough decisions to other institutional arrangements (such as WTO panels) that are subjected to, or insulated from, different political or other pressures. ${ }^{107}$ The extent to which a panel might

${ }^{104}$ See DSU art. 3(2).

${ }^{105}$ In a nonviolation complaint, which is a concept that was developed under the prior GATT, a signatory state argues that an objective of the Agreement is being impeded by a measure applied by another member state, whether or not it strictly conflicts with the terms of the Agreement. See General Agreement on Tariffs and Trade 1994, art. XXIII (b)-(c), Apr. 15, 1994, WTO Agreement Annex IA [hereinafter GATT] (recognizing complaint for actions that nullify or impede benefits received by a member state under the GATT or impede the attainment of the objectives of the Agreement). It is, in essence, a violation of the spirit rather than the letter of the Agreement. Article 64(2) of the TRIPS Agreement imposed a moratorium on nonviolation TRIPS complaints until January 1, 2000. See TRIPS Agreement art. 64(2). At the March 2000 TRIPS Council meeting, several countries suggested that the moratorium should remain in effect until new provisions on the "scope and modalities" of nonviolation complaints are agreed upon as contemplated by the TRIPS Agreement. Daniel Pruzin, European Countries Call for Negotiations on Geographic Indications at Farm Talks, [Mar. 24, 2000] Int'l Trade Daily (BNA), at d4. The United States took the position that the moratorium expired automatically on January 1,2000 , but indicated that it is not preparing nonviolation cases for the near future; it would, for the moment, restrict TRIPS complaints to violation cases.

${ }^{106}$ See, e.g, TRIPS Agreement arts. 13, 41(2) (requiring that enforcement of intellectual property rights should be "fair and equitable").

${ }^{107}$ See Trachtman, supra note 40, at 351 (noting that "[i]ncompleteness of specification" may be to "avoid the political price that may arise from immediate hard decisions" or "to cloak the hard decisions in the false inevitability of judicial interpreta- 
elaborate upon the standards, and develop more specific rules through litigation, may depend upon the reason that it perceives for the adoption of the standard. ${ }^{108}$ Any such developments should, however, be checked, and invocation of Article 3(2), with its somewhat self-serving declaration of a confined judicial role, is probably insufficient in and of itself.

\section{b. Procedural and Representational Legitimacy of WTO Panel Rulings}

The dispute settlement model now found in the DSU is not wholly "legalized," reflecting in several ways the vestiges of the diplomatic heritage of the GATT. For example, country-to-country consultations are a prerequisite to the filing of a claim, briefing documents are kept confidential, and hearings are not open to the public. These attributes all assume the method of mediation, negotiation, and conciliation that characterized the diplomatic model. ${ }^{109}$ This suggests that we should be cautious before endowing WTO panels with expansive lawgenerating powers. The power to create norms that govern our lives should be conferred only upon institutional mechanisms with procedural transparency. ${ }^{\text {InI }}$ We must look beyond the WTO for such mechanisms; the GATT is not the world constitution, and the WTO is not the World Supreme Court. They both fail to adhere to some of the essential standards required of institutions that would claim to exercise prescriptive authority over individuals throughout the world. ${ }^{111}$

tion").

${ }^{1 / x}$ For example, if the use of a standard reflects an agreement to permit individual member states the flexibility to pursue their different approaches, the development of a rigid universal rule would run starkly counter to the drafters' intent, and thus panels are unlikely to develop rules in such a context. In contrast, where the openness of the language is clearly attributable to the political difficulties that national governments would have encountered in the alternative event of narrowly drawn language, panels may see the development of rules as the implementation of the wishes of the drafters and thus adopt a more activist rulemaking posture.

Iint See David Palmeter, National Sovereignty and the World Trade Organization, $2 \mathrm{~J}$. WORLD INTELL. PROP. 77, 80-81 (1999) (distinguishing the WTO's diplomatic model from a legalistic model).

11" Both the United States and the EU have urged greater external transparency (principally, open hearings and removal of restrictions on publication of the parties' submissions) as part of the ongoing ministerial review of the DSU. See Van der Borght, supra note 101, at 1238-41 (describing current procedural problems with the DSU). The review was scheduled to be completed within four years of the establishment of the WTO, see Decision on the Application and Review of the Understanding on Rules and Procedures Governing the Settlement of Disputes, Apr. 15, 1994, 33 I.L.M. 1125, 1259 , but has been extended because of the volume of proposals.

"ii Although a single, universal model of procedural legitimacy would be hard to realize other than by statement in relatively abstract terms, $c f$. JÜRGEN HABERMAS, THE 
Moreover, the representational legitimacy of the WTO panels is less than ideal. ${ }^{112}$ To be sure, any unelected adjudicatory body possessed of lawmaking powers is, to some extent, insulated from democratic pressures. Indeed, insulation from majoritarian influence might be one reason for using an unelected body. But even with unelected tribunals, some level of democratic accountability usually exists; citizens whose lives are regulated by lawmakers typically have some nexus to those lawmakers. This nexus, and hence accountability, can be asserted through, for example, political powers of appointment, confirmation, or removal. ${ }^{113}$ Whether these powers are exercised directly, or by an official politically accountable to the citizenry, they establish some necessary connection between the governed and the governing.

WTO panels lack any such connection. Panel members are selected from a pool of persons who have served in their own governments, or in other capacities in the GATT, by the Director-General of the WTO, in consultation with the Chairman of the Dispute Settlement Body. ${ }^{114}$ The selection process is at best unclear, and no democratically accountable official is involved, except at several points removed from the process. ${ }^{115}$ Of course, the closeness of any

INCLUSION OF THE OTHER: STUDIES IN POLITICAL THEORY 239-52 (Giaran Cronin \& Pablo De Greiff eds., Ciaran Cronin trans., MTT Press 1998) (1996) (discussing a procedural model of democracy called "deliberative politics"), the reform of characteristics identified above as vestiges of the diplomatic model, such as the lack of transparency, would surely be an essential part of any institution claiming a prescriptive authority over individuals. And the lack of representational legitimacy in the WTO, discussed below, merely confirms that the WTO and the dispute settlement panels should not yet have such power conferred upon, or assumed by, them.

${ }^{112}$ The WTO is not the only international institution of which these questions must be asked. As new institutions of global governance arise in a variety of fields to assume greater influence in the lives of citizens of nation-states, these institutions will be pressed to conform to universal standards of democracy and legitimacy. See THOMAS M. FRANCK, DEMOCRACY, LEGITMACY AND THE RULE OF LAW: LINKAGES 15-20 (N.Y. Univ. School of Law, Pub. Law and Legal Theory Working Paper Series, Working Paper No. 2, 1999) (noting such challenges for new institutions of global and regional governance), available at http:// papers.ssrn.com.

${ }^{113}$ See, e.g., U.S. CONST. art. II, § 2, cl. 2 (authorizing the President of the United States to nominate and appoint federal judges upon confirmation by the U.S. Senate); $i d$. art. I, $\$ 3$, cl. 6 (authorizing the conduct of impeachment proceedings before the U.S. Senate).

${ }^{114}$ See DSU art. 8 (providing the requirements for composition of panels).

${ }^{115}$ The role of elected (national) officials is quite attenuated. The WTO Secretariat proposes the panel members to the disputant parties, and the DSU imposes few limits on the Secretariat's discretion. But see DSU art. 8(3) (providing that panelists generally cannot be from disputant country); $i d$. art. 8(10) ("When a dispute is between a developing country Member and a developed country Member the panel shall, if the developing country Member so requests, include at least one panelist from a develop- 
representational nexus is always difficult to maintain in the international context, absent direct elections to the international body. ${ }^{116}$ This has bedeviled the EU since its inception, ${ }^{117}$ and has been the rallying cry for the successive enlargement of the legislative and oversight powers of the European Parliament, the only directly elected EU institution. ${ }^{118}$ The EU continues to struggle with this issue, ${ }^{119}$ but it has at least balanced the powers of the unelected Commission with those of the Council of Ministers (comprising representatives of the nationally accountable governments) and the Parliament. ${ }^{120}$ And, as graphically demonstrated in 1999, the directly elected Parliament has the power to force the resignation of the unelected Commission. ${ }^{121}$

ing country Member."). If the parties oppose the nomination, which they should not do absent compelling reasons, see id. art. $8(6)$, and agreement cannot be reached within twenty days after the date of the establishment of a panel, the Director-General determines the panel composition in consultation with the Chairman of the DSB and the Chairman of the Council on TRIPS. Id. art. 8(7). To assist in this process, the Secretariat maintains a list of individuals from which panelists may be drawn. The qualifications to serve on this list are broadly stated. Panelists must be:

well-qualified gorernmental and/or non-governmental individuals, including persons who have served on or presented a case to a panel, served as a representative of a Member or of a contracting party to GATT 1947 or as a representative to the Council or Committee of any covered agreement or its predecessor agreement, or in the Secretariat, taught or published on international trade law or policy, or served as a senior trade policy official of a Member.

Id. art. $8(1)$. It is here that member states have the most direct role. Member states may, through their elected officials, suggest persons for inclusion on the list, and such persons will be added to the list if approved by the DSB. Id. art. 8(4).

1it. See Peter L. Lindseth, Democratic Legitimacy and the Administrative Character of Supranationalism: The Example of the European Community, 99 COLUM. L. REV. 628, 633-34 (1999) (discussing the "democratic deficit" that exists because of the lack of electoral responsibility of lawmakers to the "people whose "sovereignty" such lawmakers exercise); $c f$. Paul B. Stephan, The New International Law-Legitimacy, Accountability, Authority, and Freedom in the New Global Order, 70 U. COLO. L. REv. 1555, 1578-81 (1999) (discussing the diminished accountability, and the tendency of legislators to pursue their own self-interest, that results from the less direct connection between international lawmakers and those who are governed thereby).

${ }^{n 7}$ See Stephan, supra note 116 , at 1580 (discussing the accountability of different institutions of the EU).

${ }^{11 \times}$ See id. at 1580 (commenting that the European Parliament has little influence in lawmaking even though it is the only directly elected body of the EU).

${ }^{114}$ See Romano Prodi, President of the European Commission, Speech to the European Parliament (Nov. 10, 1999) (emphasizing the importance of agreeing upon institutional reform by the conclusion of the intergovernmental conference in December 2000), available at http: / / europa.eu.int.

${ }_{12 y 1}$ See Lindseth, supra note 116, at 672-74 (discussing the development of lawmaking procedures in the EU).

See Katherine Butler, EU in Crisis: Euracrats at Last Face the New Reality, THE INDEP. (London), Mar. 18, 1999, at 16, available at 1999 WL 5989107 (describing the immediate reactions to the European Commission's mass resignation). 


\section{c. Insufficiently Inclusive Perspectives}

\section{i. In the Initiation and Conduct of Claims}

In litigation before the WTO, the parties are formally member states of the WTO, and not the real parties in interest, namely, copyright owners, users, and competitors. State initiation of complaints, especially through the offices of a trade representative, may represent a significant filter that could alter both the type of cases filed and the conduct of litigation pursued. ${ }^{122}$ The immediate trade interests of a nation may not properly reflect the interests of broader groups of competitors or users. For example, the United States, as the current largest producer of software, arguably benefits from the highest level of copyright protection that can be achieved. ${ }^{123}$ In that climate, it is difficult (although not impossible) for advocates of lesser protection to impress upon the Trade Representative arguments for a position that might provide a more appropriate scope of domestic protection but extract less revenue for U.S. producers abroad. ${ }^{124}$ And arguments grounded in considerations other than trade, such as privacy or free speech, are even less likely to carry weight. Yet such trade-blinkered positions may easily become the position of the United States in international litigation. ${ }^{125}$

${ }^{122}$ See Dreyfuss \& Lowenfeld, supra note 99, at 282 (noting that "[t] here will be continuing issues on how states will choose which practices to challenge, which cases to use as vehicles for these challenges, and which states to sue").

${ }^{123}$ Many copyright scholars would disagree with the contention, but it is clearly one that would have some appeal to the U.S. Trade Representative. Indeed, the approach of the U.S. Trade Representative to balanced limits on software protection in other countries confirms this assumption. See OFFICE OF THE UNITED STATES TRADE REPRESENTATIVE, RESULTS OF SPECIAL 301 ANNUAL REVIEW (1999) (assessing proposed reforms in Australia and the Philippines).

${ }^{124}$ Some scholars have suggested that the appropriate balance between protection and public access pursued in the domestic context might be replicated in the international arena by the contest between the developed and developing countries. See J.H. Reichman, From Free Riders to Fair Followers: Global Competition Under the TRIPS Agreement, 29 N.Y.U. J. INT'L L. \& POL. 11, 25-26 (1997) (noting parallels between search for balance of protection and competition in both domestic and international spheres). To be sure, unbalanced positions will not go unchallenged by countries whose practices are questioned. But the mere resistance to such positions in adversarial proceedings does not alter the effect that this mindset will have on the content and direction of WTO cases.

${ }^{125}$ The decision of the WTO Appellate Body, see United States-Impart Prohibition of Certain Shrimp and Shrimp Products, I 110, WT/DS58/AB/R (WTO Appellate Body, Oct. 12, 1998), reprinted in 8 WTO DISPUTE SETTLEMENT DECISIONS 301, 333 (1998) (interpreting Article 13 of the DSU), permitting panels to accept amicus briefs and other submissions by interested persons other than governments, will help to ensure that a 
Moreover, the types of countries that are parties to WTO litigation may, as in all systems of common law lawmaking, affect the way in which the law is developed. The alignment of parties in TRIPS cases to date has resulted in greater opportunity for developed countries to be heard as parties, in part because only developed countries were required immediately to be in compliance with TRIPS. ${ }^{126}$ Developing countries were afforded the benefit of transitional periods with respect to most (though not all) ${ }^{127}$ obligations under TRIPS. Developing countries could, of course, immediately bring actions as complainants against developed countries; but these suits have not happened in part because of the more mature state of intellectual property laws in the developed world, and in part because of the resources involved in pursuing a claim. ${ }^{128}$

But this party alignment has also, because of current panel composition procedures, resulted in greater developing country representation on panels. Nationals of disputant countries generally do not sit in cases involving their own country; ${ }^{129}$ the effect of this provision has been particularly significant because the involvement of the EU as a party has been construed as excluding panelists from any EU member state. ${ }^{1 * 2}$ Either of these variables, party alignment or panel composi-

broader range of views are included within the process. But strict standing rules persist in narrowing, and skewing, the range of arguments that will be presented (and the range of interests represented) in the first place. See DSU art. 4(11) (outlining the role of third party member states in consultations); id. art. 10(2) (delineating the role of third party member states in proceedings before the panel); id. art. 17(4) (permitting participation of third party member states before the appellate body, but without a right of appeal to that body).

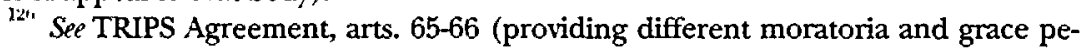
riods for different groups of TRIPS countries).

${ }^{127}$ See India-Patent Protection for Pharmaceutical and Agricultural Chemical Products, WT/DS50/AB/R (WTO Appellate Body, Dec. 19, 1997) (interpreting article 70.8 of the TRIPS Agreement and finding India to be in noncompliance notwithstanding the transitional periods applicable to full patent obligations), at http://www.wto.org.

In: Indeed, the developing countries have asked, as part of the ministerial review of the WTO system, that additional resources be made available to assist in the prosecution of claims. The DSU currently provides developing countries with legal assistance from the WTO Secretariat, see DSU art. 27(2); proposals from developing countries have focused on enlarging the Secretariat to increase that assistance. See Van der Borght, supra note 101, at 1230-32 (underscoring that developing countries often lack the experience or resources to pursue their claims effectively).

${ }_{12:}$ See DSU art 8(3) (providing that nationals of parties should not be appointed to a panel unless the parties agree); $c f . i d$. art. 8(10) (allowing developing countries litigating against developed country to request that at least one of the panelists before whom they appear will be from a developing country).

${ }^{3 * 1}$ This was anticipated in a footnote to the text of the DSU. See DSU art. 8(3) n.6 ("In the case where customs unions or common markets are parties to a dispute, the 
tion, may affect the decisional direction of WTO TRIPS jurisprudence. $^{131}$

\section{ii. In the Resolution of Disputes}

Copyright law implicates more than trade. To varying degrees in different countries, copyright is seen also as an instrument of national cultural policy, a protection of personal identity, and a means by which to enhance and further democratic ideals. ${ }^{132}$ Yet, issues before WTO panels will be largely (and possibly exclusively) refracted through a trade prism. The philosophical perspectives of WTO panel members, ${ }^{133}$ the institutional objectives of the trade body by which they are appointed, and the purposes of the trade treaty that they interpret, are each likely to alter the nature of WTO copyright discourse and the results that follow. ${ }^{134}$ Although some scholars have raised

[exclusion of panelists from such parties] applies to citizens of all member countries of the customs unions or common markets.").

131 The EU has proposed that the ad hoc panels be replaced by a standing body, not unlike the Appellate Body, comprised of between fifteen and twenty-four members. On the basis of a rotation mechanism, the Panel Body would itself form a chamber of three to deal with each new case as it arose. See Van der Borght, supra note 101, at 1240 (quoting the terms of the EU proposal to create a rotating panel body).

${ }^{132}$ See STEWART, supra note 23, at 4-12 (discussing varied justifications for copyright in countries with differing political systems); David Ladd, The Harm of the Concept of Harm in Copyright: The Thirteenth Donald C. Brace Memorial Lecture, 30 J. COPYRIGHT Soc'Y (U.S.A.) 421, 427 (1982-1983) ("Copyright ... is intended to support a system ... in which authors and publishers compete for the attention and favor of the public, independent of the political will of the majority, the powerful, and above all the government, no matter how unorthodox, disturbing, or revolutionary their experience, views or visions."); Netanel, supra note 72, at $455-58$ (noting that Berne's aim of ensuring high levels of protection "has been tempered by a long tradition of limiting authors' rights where necessary to further education and the free flow of information").

${ }^{133}$ Fred Abbott suggests that international officials with a background in intellectual property law have a history of skeptical public policy analysis of intellectual property rights while trade specialists do not have that background. Abbott, supra note 10 , at 675-76. Although those appointed to TRIPS panels are likely to be experts in the intellectual property field, the standing Appellate Body (which is intended to provide some continuity and consistency in the WTO system) will not necessarily possess comparable knowledge. See Dreyfuss \& Lowenfeld, supra note 99, at 322 (discussing the composition of the dispute settlement panels and Appellate Body respectively).

${ }^{134}$ See generally Philip M. Nichols, Extension of Standing in World Trade Organization Disprutes to Nongovermment Parties, 17 U. PA. J. INT'L. ECON. L. 295, 300 (1996) (arguing that if the WTO "forces countries to reform their laws so as to exalt the value of free trade over other values, the empirical legitimacy of national laws could be eroded"); Philip M. Nichols, Trade Without Values, 90 Nw. U. L. REV. 658 (1996) (warning that overemphasis on free trade, without consideration of other national and societal values may undermine support for the international trade regime). 
creative (and plausible) arguments as to how WTO panels might justify reference to the broader objectives of copyright law through various interpretive devices of the Vienna Convention, ${ }^{135}$ the text of TRIPS and the institutional structure of the WTO provide little comfort that broader visions of the role of copyright law in contemporary society will be considered. International copyright law might thus develop without reference to the full set of values that inform its development in national courts throughout the world. ${ }^{136}$

While the legitimacy of WTO panel decisions rests upon not addressing matters outside the trade agreement to be interpreted, and thus upon confining the panels' legal jurisdiction to their competence in trade issues, copyright does receive affirmative treatment in TRIPS. WTO panels, therefore, may consider some copyright values without exceeding their jurisdiction. This is different from panels faced with the choice of balancing trade with environmental or labor values, for the policies underlying the latter receive no expression in the GATT. $^{137}$ Despite this, however, TRIPS remains an incomplete picture of copyright values into which neighboring trade values (and not others) will bleed with some influence upon the color of analysis. ${ }^{139}$

$15^{5}$ See Helfer, supra note 1 , at 360 (arguing that dispute settlement panels will find better solutions by looking to international courts and tribunals rather than by looking solely within the WTO); Netanel, supra note 72, at 497 (arguing that "[e]specially after [the conclusion of the WIPO Copyright Treaty, WTO panels] cannot see copyright simply in terms of comparative economic advantage and world trade").

This is particularly problematic if a proper social balance of incentive and access is calibrated by reference to principles strictly situated outside the confines of copyright proper. See Lucie Guibault, Limitations Found Outside Copyright Law, in THE BOUNDARIES OF COPYRIGHT, supra note 69 , at 42 (noting limits on copyright imposed by consumer protection law, competition law, and constitutional free speech concerns). Because copyright issues are increasingly likely to arise in connection with matters wholly outside the panels' competence or jurisdiction-such as competition law, principles of freedom of expression, and issues of privacy-the trade-centric nature of the WTO's jurisdiction may become even more troubling. See Paul Edward Geller, Intellectual Property in the Global Marketplace: Impact of TRIPS Dispute Settlement?, 29 INT'L LAW. 99, 115 (1995) (expressing concern over the trade orientation of TRIPS panels in light of the fact that intellectual property "will increasingly develop and be exploited worldwide within telecommunications networks").

${ }^{1 * 7}$ See Trachtman, supra note 40, at 364-67 (suggesting ways in which WTO panels might approach the trade/environment interaction).

${ }^{135}$ Other principles could only be brought in through another interpretive device found in Article 3(2) of the DSU. See DSU art. 3(2) (affirming that dispute settlement is intended "to preserve the rights and obligations of $[\mathrm{m}]$ embers under the covered agreements, and to clarify the existing provisions of those agreements in accordance with customary rules of interpretation of public international law"). These rules of interpretation are found in the Vienna Convention on the Law of Treaties, and include principles of customary international law. See Vienna Convention on the Law of 


\section{d. Premature Entrenchment of Fundamental Norms}

Although this Article explores ways to address the concern that public international lawmaking is an unwieldy process which does not easily address new technological issues, it may be that public international copyright lawmaking is inherently and appropriately limited in this regard. As I suggest in Part III, the solution may partially lie outside of the public international lawmaking process. Several further critiques of using WTO panels to supply the missing elements of effective internationalization reinforce such a conclusion. These critiques flow from the fear that, notwithstanding the lack of formal adherence to stare decisis, ${ }^{199}$ dynamic panel interpretation of new technological issues may prematurely entrench a particular rule of copyright law as a

Treaties, May 23, 1969, arts. 31-32, 1155 U.N.T.S. 331, 340 (providing rules for the interpretation of treaties). Treaties, such as those administered by the WIPO, can be used to evidence an emerging norm of customary international law. It is upon this provision that Neil Netanel carefully constructs his argument for a broader perspective in WTO copyright litigation. See Netanel, supra note 72, at 475-79 (concluding that free speech values must be considered by WTO panels when evaluating copyright disputes since such values are part of customary international law).

${ }^{139}$ The GATT system never treated the decisions of GATT panels as binding precedent and that has carried over into the WTO system, notwithstanding the move from a diplomatic to adjudicatory model. See Chua, supra note 101, at 171 (analyzing the legal effect of panel decisions); Geuze \& Wager, supra note 97, at 351 (discussing the precedential effect of the first TRIPS panel and Appellate Body Report). The Appellate Body of the WTO has thus far declined to treat panel decisions as binding precedent; it has noted only that because earlier decisions create "legitimate expectations among WTO Members" they should be taken into account when relevant to later disputes. See WTO Appellate Body, Japan-Taxes on Alcoholic Beverages, WT/DS8/ $\mathrm{AB} / \mathrm{R}, \mathrm{WT} / \mathrm{DS} 10 / \mathrm{AB} / \mathrm{R}, \mathrm{WT} / \mathrm{DS} 11 / \mathrm{AB} / \mathrm{R}$ (Nov. 1, 1996), 1 WTO Dispute Settlement Decisions 193 (discussing whether the adoption of a panel report should be treated as subsequent practice, defined by the Appellate Body as "a "concordant, common and consistent' sequence of acts or pronouncements ... sufficient to establish a discernible pattern implying the agreement of the parties regarding its interpretation"), available at http://www.wto.org. Even without the formal status of precedent, however, it is clear both that decisions will serve as persuasive authority before subsequent panels and the Appellate Body and that states will feel pressure to follow decisions on like issues lest a parallel complaint is filed against them. If a state decides to disregard a prior dispute settlement body ruling on a similar issue, it is more likely to be in the belief that no other country will file a complaint or that any sanctions that it might suffer are a cost worth bearing rather than that the prior ruling is unpersuasive. For a thorough discussion of whether Appellate Body adjudications are binding precedent and whether a system of stare decisis does in fact operate before the WTO, see Raj Bhala, The Precedent Setters. De Facto Stare Decisis in WTO Adjudication (Part Two of a Trilogy), $9 \mathrm{~J}$. TRANSNAT'L L. \& POL. 1 (1999). Bhala contends that "[a]bnegation of stare decisis in international trade law is foolish," and concludes that the "WTO Appellate Body behaves very much like a high court (or the highest court) in a common law jurisdiction." Id. at 2, 4; see also Raj Bhala, The Myth About Stare Decisis and International Trade Law (Part One of a Trilogy), I4 AM. U. INT'L L. REV. 845 (1999) (discussing the role of stare decisis in international trade). 
fundamental (and hence mandatory) norm of international copyright. Indeed, the unwieldy nature of the treaty revision process required in order to reverse such a decision only exacerbates this consequence. ${ }^{140}$

\section{i. Erosion of Appropriate National Autonomy}

Because a decision of the DSB has the practical effect of articulating a rule of public international law, it effectively circumscribes national lawmaking options on the issue addressed. It embeds the preferred policy choice as a fundamental norm of international copyright law and may preempt national efforts to develop copyright policies tailored to particular social, cultural, and economic conditions. Of course, DSB determinations do not of themselves directly affect national copyright law and policy because signatory states retain their sovereign power to decide whether to conform their law to the international standard or to adhere to a different, indigenous approach. ${ }^{141}$ The latter choice, however, carries with it the risk of significant trade sanctions.

While classical public international lawmaking established a minimum threshold based upon the common copyright experience of a range of diverse states, it consciously reserved for national determination those issues upon which experience demonstrated divergent national priorities. The rush to force commonality on new copyright standards-understandable for the reasons canvassed in Part I of this Article-prevents appropriate assessment by member states of the need for distinctive national policies. For example, different countries with varying educational practices and literacy rates may permit or prohibit quite different copying practices. The manner in which authors are compensated may differ from country to country depending upon established labor and employment practices. The ways in which works are exploited, and thus need to be protected, may hinge upon social customs unique to particular countries. The extent of reasonable copying privileges may reflect the level of access to public libraries. Commitments to free expression, and hence use of a work in that cause without the need for permission, may vary in intensity

I*" See supra text accompanying notes 97-98; see also Thomas Cottier, Remarks at the Review of the WTO's Dispute Settlement Understanding: Which Way?, $1 \mathrm{~J}$. WORLD INTELL. PROP. 447, 464-65 (1999) (noting that the "cumbersome" nature of the process of international negotiation eliminates any real legislative check on judicial power).

14i See Palmeter, supra note 109, at $89-91$ (arguing that the possibility of being sued before the WTO does not diminish a nation's sovereignty). 
depending upon the political development of the society in question. ${ }^{142}$ Unqualified respect for the integrity of artistic works might be affected by different notions of property. And market mechanisms necessary to support schemes for compensating authors might be more feasible in certain cultures than in others.

To be sure, these are the tough cases. They force us to consider under what circumstances we are willing to tolerate different national copyright laws, and on which occasions it is more important that international standards are observed. It may be that, for the reasons discussed in Part I, international uniformity must now weigh more heavily in the equation. And because of cultural convergence across countries, nationally delimited copyright laws may carry less normative force as an instrument of cultural policy. In other words, in a world where culture is less nationally driven, national solutions may have lost some of their appeal. This claim would, however, be contested by those who view globalization as enhancing the need to assert distinctive and autonomous national cultural policies. ${ }^{1 * 8}$ At the very least, premature abnegation of the means by which nations make this determination is unhelpful. In addition to muffling cultural diversity, precipitous, mandatory, universal rules, possibly produced with input from only two litigating countries, might frustrate basic compliance with international standards. ${ }^{144}$

\section{ii. Foreclosing the Laboratory Role of Nations}

The development of alternative national policies also serves an important role in the international lawmaking process. Different national approaches to novel issues function as helpful experiments in designing a new international standard. For the reasons identified in

${ }^{142}$ Compare Texas v. Johnson, 491 U.S. 397 (1989) (finding flag burning to be speech protected by the First Amendment) with Hong Kong Special Admin. Region v. Ng Kung Siu, FACC No. 4 of 1999 (Dec. 15, 1999), http://www.info.gov.hk/jud/ guide2cs $/ \mathrm{html} / \mathrm{cfa} / \mathrm{judmt} /$ facc_4_99.htm (upholding a conviction for defacing a flag based upon the newness of the "one country two system" principle, reasoning that at this stage in Hong Kong's history this was a restriction necessary to preserve legitimate social interests and thus consistent with Article 19(3) of the International Covenant on Civil and Political Rights).

${ }^{143}$ See, e.g., Satvinder S. Juss, Book Review, 6 IND. J. GLOBAL LEG. STUD. 371, 380 (1998) ("The very factors that cause a sense of borderlessness also force communities to look inwardly and determine what control they retain over their destinies.").

${ }^{144}$ Cf. Dreyfuss \& Lowenfeld, supra note 99, at 306-07 ("Setting a worldwide standard on [fair use] would ... reduce flexibility and produce a kind of cultural homogenization that might either induce noncompliance or turn the world into a much less stimulating environment."). 
Part I, at some point the different experiments should ideally converge toward common understandings (and the need for this has arguably become more urgent). But experimentation enables the common understanding (the international standard) to be forged by experience, which should assist in identifying an appropriate standard. Copyright-rich countries are obviously reluctant to allow national experimentation with different levels of protection before bringing the issue to an international arena. By hastening the adoption of an international norm through an assertive WTO (or any other) process, however, an important benefit to the international lawmaking process is forfeited.

\section{iii. Problems of TRIPS Interpretation}

TRIPS presents an interpretive challenge with which domestic courts faced with new copyright issues are not confronted: it does not purport to state ideal standards or principles from which a panel might develop new rules. It merely imposes a set of minimum standards. We have had no experience in copyright law of imbuing minimum standards with enforceable meaning, because prior to the TRIPS Agreement, there was no effective means of enforcement. This may affect in several ways the capacity of the WTO dispute settlement panels to accomplish the international lawmaking that some might wish. First, do the usual devices that courts use to interpret legislative text work in this arena? Given that the stated standards are not intended to operate as the most efficient or most balanced, or optimal rule, what weight is to be given to methods of reasoning that are informed by those values? ${ }^{145}$ Of course, the minimum standards approach embodied in TRIPS, as in the Berne Convention before it, does not reflect a desire to promote suboptimal rules of copyright law. Rather, the varied social, cultural, and economic conditions of different coun-

${ }^{145}$ Copyright law is frequently analyzed by reference to economic efficiency. See generally William M. Landes \& Richard A. Posner, An Economic Analysis of Copyright Law, 18 J. LEGAL STUD. 325, 325 (1989) (discussing "to what extent copyright law can be explained as a means for promoting efficient allocation of resources"). More specifically, it is often calibrated by reference to the optimal balance between incentive and access. See Alice Haemmerli, Insecurity Interests: Where Intellectual Property and Commercial Law Collide, 96 ColuM. L. REV. 1645, 1686 (1996) ("[C]opyright law attempts to strike a balance, promoting economic efficiency when it maximizes the benefits from the creation of new works minus the losses from limited access and enforcement costs."); see also Nash v. CBS, Inc., 899 F.2d 1537 (7th Cir. 1990) (Easterbrook, J.) (canvassing different considerations that determine the appropriate scope of copyright protection). 
tries may require deviations from a single standard; the whole notion of an "optimal" law is politically, culturally, and economically contingent. $^{146}$ If we wished to divine from TRIPS a universal optimal rule of copyright law, we would have to assess those contingencies in a global context. This interpretive dilemma merely confirms TRIPS' properly more limited role: it does not announce, and does not of itself provide the grounding for, universal rules of copyright law.

Second, the approach of articulating minimum standards of protection and permitting any higher (but not lower) level of protection means that TRIPS ${ }^{147}$ (properly interpreted) has very little to say in addressing the most contested issues presented by current technology. The predominant national approach to digital copyright issues throughout the world has been to classify most acts by users as within the prima facie exclusive control of the copyright owner, and then to create a proper balance by enacting exceptions and limitations to that general principle. ${ }^{148}$ Yet, international copyright treaties rarely address exceptions and limitations on the rights of an owner ${ }^{149}$ other

${ }^{146}$ See Hanns Ullrich, GATT: Industrial Property Protection, Fair Trade and Development, in GATT OR WIPO? NEW WAYS IN THE INTERNATIONAL PROTECTION OF INTELLECTUAL PROPERTY 127, 146-59 (Friedrich-Karl Beier \& Gerhard Schricker eds., 1989) (discussing the dangers of identical protection in differently situated countries).

${ }_{147}$ This is true of any current global multinational copyright treaty, for each adopts the minimum standards approach. The EU Directives, in contrast, do contain substantive maxima, that is, mandatory exceptions to, or limits on, copyright. See, e.g., Software Directive, supra note 84, art. 6 (creating a decompilation exception); Common Position Adopted by the Council with a View to the Adoption of a Directive of the European Parliament and of the Council on the Harmonisation of Certain Aspects of Copyright and Related Rights in the Information Society, art. 5(1) (Sept. 14, 2000), at http://register.consilium.eu.int/pdf/en/00/st09/09512en0.pdf [hereinafter Proposed Information Society Directive Common Position] (requiring exceptions from scope of copyright for certain temporary acts of reproduction with no independent economic significance).

${ }^{148}$ This is implicit in most recent legislative enactments. See, e.g., 17 U.S.C. $\$ 512$ (Supp. IV 1998) (providing safe harbors for service providers); Proposed Information Society Directive Common Position, supra note 147, art. 2 (requiring that member states provide authors "the exclusive right to authorize or prohibit direct or indirect, temporary or permanent reproduction by any means and in any form, in whole or in part").

${ }^{149}$ The Berne Convention does include various provisions delineating permissible exceptions to the exclusive rights of an author. See Berne Convention, supra note 15 , art. 10, 1161 U.N.T.S. at 38 (permitting quotations and use of literary and artistic works by way of illustration for teaching purposes, provided that such quotation or use is compatible with fair practice); $i d$. art. $10 b i s, 1161$ U.N.T.S. at 38 (allowing exceptions for the reporting of current economic, political, or religious events). The Convention also permits, but does not require, certain compulsory licenses. See, e.g., id. art. 11 bis(2), 1161 U.N.T.S. at 38 (permitting member states to subject the broadcast right to a compulsory license); $i d$. art. 13(1), 1161 U.N.T.S. at 39 (permitting member states 
than to the extent that they are not allowed..$^{150}$ Exceptions and limitations are areas where national autonomy has heretofore been given relatively free rein. ${ }^{151}$ This might have been justified when those exceptions were truly expressions of national cultural policy. ${ }^{152}$ But where exceptions become as integral to the balance of copyright as they must be when broad prima facie protection is conferred, greater internationalization must be pursued than can be provided by minimum standards. In the interim, this confirms that TRIPS would provide little basis upon which WTO panels could extract and develop a useful approach to new technological issues. ${ }^{153}$

Third, and again made important by the likely emphasis on exceptions and limitations in the digital environment, WTO panels are ill-equipped to develop nuanced solutions or finely tuned balances of the rights and privileges of producers and users. Formally, since WTO complaints will be based upon legislative deficiencies or (possibly) a collection of case law revealing a pattern of nonenforcement, the WTO panel often will not decide particular factual disputes, but rather assess abstract rules of law. The calibration of exceptions (such as fair use) is a notoriously fact-specific exercise. Although the extent to which breaches of obligation based upon national court decisions

to allow third parties a compulsory license to record musical works previously recorded).

${ }_{1: n+1}^{5}$ See TRIPS Agreement art. 13 ("Members shall confine limitations or exceptions to exclusive rights to certain special cases which do not conflict with a normal exploitation of the work and do not unreasonably prejudice the legitimate interests of the right holder."); Berne Convention, supra note 15, art. 9(2), 1161 U.N.T.S. at 37 (permitting legislatures to enact exceptions permitting certain reproductions of literary and artistic works).

${ }^{151}$ See supra note 64 and accompanying text (describing the generous room granted member states to create exceptions to copyright under the Berne Convention).

See Dreyfuss \& Lowenfeld, supra note 99, at 306 (arguing against worldwide standards on fair use because "[ $t]$ he extent to which fair use is considered necessary depends upon fundamental national values such as the importance and extent of free speech, on artistic traditions, and on aesthetic sensibilities"); Ginsburg, supra note 55, at 3,23 (commenting that "exceptions to copyright present a more difficult, but potentially persuasive, case" for reservation to national norms, and concluding that "[s]everal considerations . . . point toward discrete territorial application of local norms limiting copyright, even for digital transmissions").

${ }^{153}$ It is perhaps unsurprising that two of the first four TRIPS reports handed down by the WTO dispute settlement panels, including the only copyright dispute upon which a report has been issued to date, involve exceptions to intellectual property rights. See WTO DSB Panel, United States-Section 110(5) of the U.S. Copyright Act, Doc. No. WT/DS160/R (June 15, 2000); WTO DSB Panel, Canada-Patent Protection of Pharmaceutical Products, Doc. WT/DS114/R (Mar. 17, 2000). 
will require a pattern of activity remains unclear, ${ }^{154}$ WTO panels will not be presented with cases in a fashion that permits development of international standards regarding the scope of exceptions to copyright because WTO dispute settlement proceedings will likely focus on a state's systematic failure to uphold its obligations.

In sum, these final critiques suggest that WTO panels should not actively develop international standards beyond those clearly presented in the TRIPS text. ${ }^{155}$ The nature of the TRIPS Agreement, and the posture of the cases with which they will be confronted, means that panels are poorly equipped to do so. Moreover, such efforts would adversely affect the role of national autonomy in recognizing cultural differences and adopting fully tested approaches as international standards.

\section{Rejecting Internationalization?}

These last observations regarding the WTO dispute settlement process suggest that there is a danger in overemphasizing the need for

${ }^{154}$ See Dreyfuss \& Lowenfeld, supra note 99, at 282 (noting that "[t]here will be continuing issues on how states will choose which practices to challenge"); $c f$. WTO DSB Panel, United States-Section 110(5) of the U.S. Copyright Act, WT/DS160/R (June 15, 2000), at II 6.138-144 (looking at the practices of a "vast majority" of U.S. courts as evidence of the meaning of the statutory provision and declining to consider how analysis of U.S. TRIPS compliance might be affected were, as the EU hypothesized, a series of U.S. courts to adopt generous interpretations of the statutory language), at http://www.wto.org.

${ }^{155}$ My critique of an aggressive use of WTO panels should not be taken as a lack of support for strict enforcement of the substantive copyright obligations clearly undertaken by TRIPS signatories. The availability of WTO dispute settlement procedures and the concomitant enforcement mechanisms has transformed international intellectual property law in important and generally beneficial ways. I view the obligations of TRIPS as setting external boundaries (both floors and, ideally in the future, ceilings) for permissible copyright protection, within which member states have latitude to develop indigenous approaches to copyright. These boundaries would converge over time as consensus develops on fundamental norms of contemporary copyright law. Public international law should represent the rough filter in a process of internationalization. The finer filter, as I argue below in Part III, should be the process of private international copyright lawmaking. This process should facilitate more nuanced solutions that will generate the common understanding necessary for later implementation as public international law standards. This approach allows room for initial experimentation. It also reflects concerns about the legitimacy of the WTO process; if a broad consensus has developed on an issue, that consensus will serve as a surrogate for the ideal representational state that might otherwise support more intrusive UTO lawmaking. The forms of private international lawmaking discussed in Part III, with their more direct tie to political and democratic legitimacy and their susceptibility to prompt legislative reversal, have a much stronger claim to immediate application over the lives of global citizens. 
internationalization, or at least a danger in seeking to internationalize too promptly. Yet, at times the current trend to harmonize national copyright laws seems inexorable. Even if the substance of particular initiatives has been questioned, the process has been largely welcomed as an important means of nourishing the political and economic globalization to which law increasingly has become servant.

Dissenting voices have been raised, however, both by scholars of copyright law and those in other disciplines. ${ }^{156}$ The copyright scholars in question have largely bemoaned the process as being subverted to what they view as narrow economic ends. ${ }^{157}$ Other legal scholars have launched more direct attacks on the current processes of internationalization. Paul Stephan, for example, has expressed skepticism as to whether unification and harmonization of international commercial law is necessary or helpful. ${ }^{158}$ Stephan's indictment of the process arises from observations of international commercial law (in the form of model laws and conventions), which he criticizes as producing either open-ended rules that confer unfettered discretion on domestic decisionmakers, or precise rules that benefit discrete interest groups. $^{159}$

Stephan's first criticism, of futility, is an important one. But, even

15i The process of globalization itself has been the subject of significant criticisms by scholars in other fields of intellectual inquiry and by popular commentators. See generally WILlLAM GREIDER, ONE WORLD, READY OR NOT: THE MANIC LOGIC OF GlOBAL CAPITALISM (1997) (analyzing the "global industrial revolution" of the late twentieth century and concluding that the logic of commerce and capital was overwhelming consideration of the consequences of this "revolution"); MICHAEL P. RYAN, KNOWLEDGE DIPLOMACT: GLOBAL COMPETTIION AND THE POLITICS OF INTELLECTUAL PROPERTY (1998) (discussing the political development of international intellectual property law and policy).

${ }_{157}$ See, e.g., Kenneth D. Crews, Harmonization and the Goals of Coppright: Property Rights or Cultural Progress? 6 IND. J. GLOBAL LEG. STUD. 117, 118 (1998) (arguing that international harmonization "has brought distinct change to U.S. law in ways contrary to the fundamental purposes of copyright law and its social objectives"); Jaszi, supra note 22, at 598-99 (complaining that arguments grounded in "traditional visions" of copyright were being ignored by Congress and that TRIPS-implementing legislation was instead animated by a new vision of copyright, namely "to improve the competitive position of companies that have significant investments in inventories of copyrighted works").

15\% Stephan, supra note 14 , at 744 .

$15 "$ See id. at 767-68 (detecting the "fingerprints" of special interests on precise rules regarding sea transport); $i d$. at 774-79 (suggesting that the Convention on the International Sale of Goods contains rules that "allow virtually unbounded discretion to the decisionmaker who must apply them"). Stephan attributes the flaws in the products of these gatherings of experts in international and comparative law to the "inherent limitations in the process that generates international agreements for national implementation." Id. at 744. 
baseline rules are transgressed-a series of negotiated settlements of copyright TRIPS disputes bears witness to such transgressions. ${ }^{160}$ And copyright is, for many countries, a more recent legal innovation than such notions as contracts of sale. Even the general, basic norms contained in treaties emanating from the classical public international copyright lawmaking process may be of significant effect as countries construct copyright laws for the first time. ${ }^{161}$ Stephan's second criticism-that precise rules emanating from the international lawmaking process benefit discrete interest groups-is also serious, though the extent to which such a phenomenon differs from that at play in developing national legislation is not entirely clear. ${ }^{162}$

As we engage in international copyright lawmaking, futility and rent-seeking are certainly criticisms that should be borne in mind, along with concern for national autonomy, the role of national laws in developing international standards, and accommodating the diverse range of interests now affected by copyright. The concerns noted earlier in this Article-namely, the costs of insufficient protection internationally and the need for copyright law to address new technological issues-are, however, also important. Therefore, the limits of the public international lawmaking process should not constrain our search for other means of internationalizing copyright law. ${ }^{163}$ Having

${ }^{160}$ See OFFICE OF THE UNITED STATES TRADE REPRESENTATTVE, RESUlTS OF SPECLAL. 301 ANNUAL REVIEW (1999) (discussing settlement of disputes with Sweden and Denmark).

${ }^{161}$ Blatant violation of uncontested norms may happen not only in countries without established copyright regimes but also in countries where short-term domestic political pressures make this an attractive option. Indeed, the availability of TRIPS dispute resolution may paradoxically embolden national legislators under pressure to succumb to the short-term arguments with the knowledge that the long-term position will be rectified by the WTO.

${ }^{162}$ Paul Stephan himself has considered that question. See Paul B. Stephan, Accountability and International Lawmaking: Rules, Rents and Legitimacy, 17 NW. J. INT'L. L. \& Bus. 681, 682-83 (1996-1997) (considering differences in accountability between international and national lawmakers). He consciously draws on earlier work by Robert Scott and Alan Schwartz in the domestic context of the drafting of the UCC. See Alan Schwartz \& Robert E. Scott, The Political Economy of Private Legislatures, 143 U. PA. L. REV. 595, 597 (1995) (examining "how large private law-making groups" work); Robert E. Scott, The Politics of Article 9, 80 VA. L. REV. 1783, 1803-22 (1994) (suggesting that "the U.C.C. lawmaking process functions like a private legislature").

${ }^{163}$ Stephan's analysis, like this Article, seeks to go beyond traditional models and considers the recent spate of activity in international "private legislatures." See Stephan, supra note 14, at 756-57. For the reasons mentioned in the text, Stephan questions whether these bodies can add to the process of creating international commercial law. See id. at 761 (doubting the value of past efforts to achieve unification and harmonization). 
suggested desirable and inevitable limits on the capacity of public international models, either classical or new, to serve as the sole mechanism of international copyright lawmaking, I next consider whether private law alternatives might contribute to that process. ${ }^{164}$

\section{PRIVATE INTERNATIONAL COPYRIGHT LAWMAKING}

Further progress toward the formulation of international norms might be possible, without implicating as directly the problems posed

lit Stephan's solution to what he sees as the futility of harmonization as an instrument of international lawmaking is instructive. He would encourage parties contractually to agree upon a national law to govern their international commercial transaction (and reduce the policing of such choices by courts). See id. at 789 . And there may be good, practical reasons for greater deference to choice of law clauses in international transactions. See RESTATEMENT (SECOND) OF CONFLICT OF LAWS $\$ 187, \mathrm{cmt}$. $\mathrm{f}$ (1971) (suggesting that greater latitude be afforded parties' choices of law in the international context). Thus, in common with my proposal in Part III below, Stephan is willing to involve private parties more fully in responding to the pressures of internationalization. But he repudiates the goal of international standards, instead preferring to facilitate international commerce by contractual localization. Other scholars have also sought to elevate party autonomy as a means of addressing the increasingly large volume of conflicts problems. See, e.g., Erin A. O'Hara \& Larry E. Ribstein, From Politics to Efficiency in Choice of Law, 67 U. CHI. L. REV. 1151 (2000). O'Hara and Ribstein draw heavily upon arguments of jurisdictional competition. To be sure, there may be significant efficiency gains to be garnered by recognizing party autonomy, so that only minimal policing of choice of law clauses might be warranted. Indeed, to some extent, my discussion below of the potential of international copyright arbitration is based upon relatively unquestioned enforcement of forum (i.e., arbitral tribunal) selection clauses and choice of law (lex informatica) clauses. But the nature of copyright prevents overreliance on this device for resolving copyright conflicts. Arguments based upon competitive markets (or state experiments, depending upon how one justifies this approach) are persuasive only if the effects of state choices as to the content of law can be confined to that state. One can assess the effects of experiments only if external variables are controlled and all "background noise" is filtered out. See Bledsoe v. Crowley, 849 F.2d 639, 646-47 (D.C. Cir. 1988) (Williams, J., concurring) (considering the systemic interests of states' experimentation as part of choice of law analysis). If State $A$ relied on a wholly free market system, rather than copyright, to generate new creative endeavors sufficient to keep its citizenry educated and informed, the effect of that choice cannot be measured if the citizenry can easily, and does in fact, obtain access to information from other states pursuing different information policies. Similarly, State $A$ 's choice will, by virtue of the nature of intangible works, infect other states' experiments. For example, if State $A$ relied on the free market, producers in State $B$ would suffer widespread infringement and uncompensated use in State $B$ as a result of the laws in State $A$. Consequently, the producer in State $B$ would have to raise its prices for reasons unrelated to the content of laws in State $B$. Cf. William W. Bratton \& Joseph A. McCahery, The New Economics of Jurisdictional Competition: Devolutionary Federalism in a Second-Best World, 86 GEO. L.J. 201, 219-43 (1997) (discussing limits of competitive federalism model). Thus, although recognition of party autonomy may assist in developing a lex informatica through international arbitration, such choices may warrant some policing in part because of their inability to generate the gains claimed. 
by public international lawmaking, if the articulation of those norms took a different form. In particular, in this Part of the Article, I consider two private law mechanisms that might contribute to the international copyright lawmaking process: copyright arbitration using international norms, and the adoption of a new choice of law methodthe substantive law method-by courts deciding international copyright infringement cases.

\section{A. International Copyright Arbitration}

In international commerce, parties frequently agree to submit disputes to arbitration. In that context, arbitrators may decide cases (and parties may argue cases) according to the customs and standards of international commerce rather than the norms of any national legal system. Parties may in their contract expressly reference these standards as applicable to any dispute under the contract, but these standards may also inform decisions when the parties make no contractual provision for choice of a national law. ${ }^{165}$ These standards, known as lex mercatoria, are accepted by many participants in international commerce and, though developed by private law adjudication, contribute to the recognition and development of norms of international commerce. Could the arbitration of international copyright disputes, by reference not to national copyright laws but to a version of the lex mercatoria, enable the recognition and development of international copyright norms? Some authors believe that this is at least possible, or even advisable, in the particular context of the internet, where a lex informatica might prevail. ${ }^{16}$

Several variables affect the likelihood that this might occur,

${ }^{165}$ See Klaus Peter Berger, International Arbitral Practice and the UNDROIT Principles of International Commercial Contracts, 46 AM. J. CoMP. L. 129, 145-46 (1998) (noting the possibility of applying lex mercatoria "when the parties have not chosen any system or rules of law to govern their contract" (quoting OLE LANDO \& HUGH BEALE, THE PRINCIPLES OF EUROPEAN CONTRAGT LAW Art 1.01 (3) (b) (1995))) . In practice, it may also occur when parties have selected an applicable law. See $i d$. at $140-42$ (detailing the application of lex mercatoria principles in a Dutch-Turkish arbitration specifying Dutch law (unpublished ICC-Award No. 8486 of 1996)).

${ }_{166}$ See, e.g., Aron Mefford, Lex Informatica: Foundations of Law on the Internet, 5 IND. J. GLOBAL LEGAL STUD. 211, 223-37 (1997) (examining the possibility of a lex informatica developing for the internet); see also I. Trotter Hardy, The Proper Legal Regime for "Cyberspace", 55 U. PITT. L. REV. 993, 1019-25 (1994) (discussing the parallels between Law Merchant and rules governing in cyberspace); David R. Johnson \& David Post, Law and Borders-The Rise of Law in Cyberspace, 48 STAN. L. REV. 1367, 1387-91 (1996) (discussing the rise of a separate law of cyberspace). 
whether in the internet context or offline. ${ }^{167}$ First, in the past, arbitration between private parties of a claim of copyright infringement has rarely occurred. Disputes may come before arbitration tribunals in two ways: by ad hoc submission to arbitration after a dispute arises, or by enforcement of an ex ante contractual arrangement. Ad hoc submission of a copyright dispute to arbitration will rarely occur in infringement cases absent, perhaps, the desire for a continuing relationship between the parties. ${ }^{168}$ Facilities such as the WIPO Arbitration Center, which offer copyright arbitration expertise, have thus been somewhat underused. Contractually agreed arbitration of copyright infringement claims has also been rare. Traditional copyright litigation can be divided into three basic types: actions by copyright owners against pirates; actions by copyright owners against legitimate competitors (and, increasingly, assertive users); and, copyright owners in disputes with co-exploiters or putative co-owners. This third setting is essentially a contract dispute which could be litigated as a copyright complaint if framed as owner-privileged conduct occurring without authorization. It is here that arbitration could be most significant in the traditional bricks-and-mortar context, because it is only in this setting that ex ante contractual arrangements are likely to be in place.

Second, it is unclear what effect private arbitration of copyright disputes might have upon setting the boundaries of cultural or social policy. Arbitration need not be public; indeed, one of the advantages it may offer participants is secrecy. In order for the lex mercatoria to assist in the development of the norms of international commercial conduct, in addition to providing a basis for adjudication of disputes, it must cast a discernible shadow over relevant actors. International

${ }^{1 / 7}$ Various private efforts at articulating standards of international commercial law can be identified. See, e.g., Joseph M. Perillo, UNWROIT Principles of International Commercial Contracts: The Black Letter Text and a Review, 63 FORD. L. REV. 281, 282 (1994). Some scholars have recently sought to develop an international copyright code. See, e.g., J.A.L. STERLING, WORLD COPYRIGHT LAW 709-11 (1998) (suggesting that policymakers move toward a "unified global system of copyright"); J.A.L. Sterling, International Codification of Copyright Law: Possibilities and Imperatives, Paper Presented to Eighth Annual Conference on International Intellectual Property Law and Policy, Fordham University School of Law (April 2000) (copy on file with author) (exploring the possible content of a world copyright code). And the WIPO has developed a series of model provisions that might provide guidance. Indeed, their use in this context may have greater legitimacy than as purported interpretations of public international obligations. See Cornish, supra note 77, at 337-38 (discussing the role of the WIPO in interpreting treaties).

Arbitration involving copyright issues does, however, occur in the regulatory context of establishing royalty rates under compulsory licenses. See 17 U.S.C. $\$ \S 801$ 803 (1994) (establishing Copyright Arbitration Royalty Panels). 
commercial actors must be aware that their conduct will be judged by the standards of the lex mercatoria. Its effect will also be enhanced by the administration of proceedings by a repeat administrator, such as the WIPO Arbitration Center, or the systematic publication of decisions and reasoning. Until international copyright arbitration according to norms of international conduct becomes frequent and public, its potential for contributing to international lawmaking will be limited.

Finally, since the cases most likely to be arbitrated involve disputes between co-exploiters or co-owners under agreements containing an ex ante contractual arrangement of substantive obligations, as well as selection of an arbitral forum, decisions rendered in such cases may reflect the scope of private contractual understandings rather than public-interest motivated rules of copyright law. Only if a significant number of cases without substantive contractual overlay were arbitrated would such proceedings have the capacity to develop international copyright policy.

In these different facets, one must distinguish between, on the one hand, arbitration of copyright disputes and, on the other, the arbitration of disputes between trademark holders and domain name registrants under the Uniform Domain Name Dispute Resolution Policy ("UDRP") recently implemented by domain name registrars authorized by the Internet Corporation for Assigned Names and Numbers ("ICANN"). ${ }^{169}$ The latter procedure has significant potential for the creation of international trademark norms: ${ }^{170}$ the domain

${ }^{169}$ ICANN is the nonprofit corporation established in 1998 to oversee, inter alia, the domain name management system. See Internet Corporation for Assigned Names and Numbers, at http://www.icann.com. For the Uniform Domain Name Dispute Resolution Policy, see http://www.icann.org/udrp/udrp-policy-24oct99.htm. ICANN is another international organization that has been criticized for lack of transparency and accountability and the organization continues to grapple with issues of representational and procedural legitimacy. See CENTER FOR DEMOCRACY AND TECHNOLOGY, DOMAIN NAME MANAGEMENT POLICY (2000), available at http://www.cdt.org/ dns/icann/study (last visited Aug. 15, 2000) (studying the ICANN at large election and raising issues of major concern); Jeri Clausing, The Internet's Naming Agency Agrees to Modify Elections, N.Y. TIMES, Mar. 11, 2000, at C14 (discussing revised plans for direct election of ICANN board members by individual net users); Jeri Clausing, What's in a Name?, N.Y. TMES, Mar. 13, 2000, at C9 (discussing a report by two public interest groups concluding that the proposed system for electing the ICANN board failed to ensure accountability and risked being infiuenced by special interests).

${ }^{170}$ The extent to which this is jeopardized by the enactment of arguably inconsistent national protection, such as the Anticybersquatting Consumer Protection Act, Pub. L. No. 106-113, 113 Stat. 1501, 1501A-545 to -552 , recently enacted by the U.S. Congress, is beyond the scope of this Article. Decisions of panels convened under the UDRP are not binding on national courts. See BroadBridge Media L.L.C. v. Hy- 
name registration procedure provides an opportunity to impose obligations to arbitrate; the decisions of arbitrators are published on the ICANN web site; ${ }^{171}$ and there exists, by virtue of U.S. government superintendence of the internet, ${ }^{172}$ a centralized mechanism-ICANNthrough which the uniform dispute resolution procedures can be established worldwide. ${ }^{173}$

percd.com, 55 U.S.P.Q.2d 1426, 1428-29 (S.D.N.Y. 2000) (holding that the pendency of an arbitration under the UDRP does not foreclose a concurrent court action under the Anticybersquatting Consumer Protection Act); Weber-Stephen Prod. Co. v. Armitage Hardware \& Bldg. Supply, Inc., 54 U.S.P.Q.2d 1766, 1768 (N.D. Ill. 2000) ("We conclude that this Court is not bound by the outcome of the ICANN administrative proceedings."); see also INTERNET CORPORATION FOR ASSIGNED NAMES AND NUMBERS (ICANN), UNIFORM DOMAIN NAME DisPute Resolution POLICY $\S 4(\mathrm{k})$, at http://www.icann.org/udrp/udrp-policy-24oct99.htm (last visited Sept. 17, 2000) (providing that panel decisions do not prevent the parties from pursuing lawsuits against one another in national courts). Therefore, differences between national law and the UDRP are likely to be exploited by litigants. And it is not yet clear from the early arbitration panel opinions whether panels will regard the provisions of the UDRP as self-contained or requiring regard to certain national laws under traditional choice of law analysis. See Rules for Uniform Domain Name Dispute Resolution Policy, Rule 15(a), at http://www.icann.org/udrp/udrp-rules-24oct99.htm (last visited Sept. 17, 2000) ("A Panel shall decide a complaint on the basis of the statements and documents submitted and in accordance with the Policy, these Rules and any rules and principles of law that it deems applicable."). Moreover, these tensions will only increase if (and when) the UDRP is extended, either by ICANN mandate or expansive arbitral interpretation, to more contentious issues. See Press Release, World Intellectual Property Organization (WIPO), WIPO To Probe New Issues Relating to Domain Name Abuse (July 10, 2000), available at http://www.wipo.org/eng/pressrel/ 2000/p235.htm (last visited Aug. 27, 2000) [hereinafter WIPO Press Release] (announcing, at the request of various member states, a study of whether the scope of the UDRP should be broadened to address cases such as those involving personal names of celebrities or geographical indications of origin).

${ }^{171}$ See The Internet Corporation for Assigned Names and Numbers, List of Proceedings Under Uniform Dispute Resolution Policy (2000), at http://www.icann.org/udrp/ proceedings-list.htm (last modified Nov. 10, 2000) (providing the text of all decisions handed down by ICANN-approved dispute settlement providers under the UDRP). For the text of the first decision handed down under the UDRP, see World Wrestling Fed. Ent., Inc. v. Bosman, No. D99-0001 (Admin. Panel, Jan. 14, 2000), at http://arbiter.wipo.int/domains/decisions/html (last visited Aug. 27, 2000). In the first nine months of the UDRP, almost 2000 cases were filed with the dispute settlement providers, the majority of which were arbitrated under the auspices of the WIPO Arbitration Center. Before the implementation of the UDRP, the WIPO Arbitration Center was almost unused. For an up-to-date statistical analysis of cases filed and decided, see The Internet Corporation for Assigned Names and Numbers, Statistical Summany of Proceedings Under Uniform Dispute Resolution Policy (2000), at http://www.icann.org/udrp/proceedings-stat.htm (last modified Nov. 10, 2000).

${ }^{172}$ This supervisory authority is rooted in practical power rather than legal authority. See generally Joseph P. Liu, Legitimacy and Authority in Internet Coordination: A Domain Name Case Study, 74 IND. L.J. 587 (1999) (explaining source of regulatory authority over the internet).

${ }^{173}$ The UDRP applies (by mandate of ICANN) to all disputes involving names reg- 
Although the domain name arbitration procedures present a more probable context for the development of international norms through private party arbitration, new technological means of delivering copyrighted products and the culture of a new copyright environment ${ }^{174}$ may enhance the likelihood of similar developments occurring with respect to copyright disputes. If contract were ever dead, ${ }^{175}$ the internet has given it a Lazarene revival. To be sure, the widespread contractualization of copyright law raises many difficult questions, $^{176}$ but it may also present solutions and opportunities. ${ }^{177}$

istered in the generic top level domains. These domain names can be owned by persons throughout the world. Moreover, the UDRP has already been voluntarily adopted by certain managers of country-code top-level domains, and the recently announced WIPO review of the UDRP will likely encompass the extension of the UDRP to disputes involving country-code top-level domains. See WIPO Press Release, supra note 170 (noting the request of certain member states for WIPO to "draw up a list of best practices to help administrators of country[-code] top level domain registries ... prevent and resolve domain name disputes").

${ }^{174}$ The culture of the online environment may include a significant commitment to principles of visible community justice and less adversarial forms of dispute settlement. See Ethan Katsh, Digital Lauyers: Orienting the Legal Profession to Cyberspace, $55 \mathrm{U}$. PITT. L. REV. 1141, 1155 (1994) (comparing levels of conflict in exchanges of information between lawyers online and offline). See generally Henry H. Perritt, Jr., Dispute Resolution in Electronic Network Communities, 38 VILL. L. REV. 349 (1993) (discussing how adaptation of contract law might deter potential and resolve actual disputes arising in the "electronic network communities").

175 See Grant GILMORE, The DEATH OF CONTRACT 3 (1974) ("We are told that contract, like God, is dead. And so it is.").

${ }^{176}$ See Jane C. Ginsburg, Authors as "Licensors" of "Informational Rights" Under U.C.C. Article 2B, 13 BERKELEX TECH. L.J. 945 (1998) (addressing the possible clash between copyright law and contract); Jessica Litman, The Tales that Article $2 B$ Tells, 13 BERKELEY TECH. L.J. 931 (1998) (discussing the tension between contractual rights validated by the proposed Article 2B of the UCC and current copyright law). Some scholars have argued for an international treaty provision restricting the absolute freedom of contract in copyright matters. See, e.g., Wilhelm Nordemann, Toward a Basic International Regime of Copyright Contracts, in INTELlECTUAL PROPERTY AND INFORMATION LAW: ESSAYS IN HONOR OF HERMAN COHEN JEHORAM 217, 221 (Jan J.C. Kabel \& Gerard J.H.M. Mom eds., 1998) (advocating an international agreement restricting contractual derogation of authors' rights and guaranteeing authors certain rights of remuneration).

Arbitration has been most comfortably enforced with respect to matters contractually agreed upon between private parties; party autonomy is recognized as a dominant consideration in the contractual setting. Arbitration of matters impinging upon "public law regulation," such as private actions alleging securities fraud or tort claims such as copyright infringement, has historically been more problematic. But the U.S. Supreme Court has for several years now appeared willing to give some latitude to the notion of "disputes arising under the contract," and to treat that term as encompassing traditional "public law issues," particularly when the dispute has an international component. See Scherk v. Alberto-Culver Co., 417 U.S. 506, 515-17 (1974) (upholding an arbitration clause and stressing the international nature of the dispute in support of that conclusion); cf. ANDREAS F. LOWENFEID, INTERNATIONAL LITIGATION AND THE 
Digital commerce may facilitate the use of standard form contracts with arbitration clauses and U.S. courts thus far appear willing to enforce forum selection clauses in standard click-on contracts.

It is unclear whether content providers or other participants in the information industries might be willing to subject themselves to, and thus formally to recognize or generate, international norms by submitting disputes to arbitration, either without specification of a single national law or with conscious choice of international standards. ${ }^{179}$ It may depend upon the content of national copyright alter-

QUEST FOR REASONABLENESS: ESSAIS IN PRINATE INTERNATIONAL LAW 3-5 (1996) (discussing this distinction in the context of the application of foreign law by national courts).

${ }^{177}$ For example, in the internet context, "all users (authors and infringers) are connected by means of service provider agreements, [and] those agreements can require submission of disputes to arbitral tribunals that will apply the lex informatica." Ginsburg, supra note 55, at 15 (citing Michel A. Jaccard, Securing Copyright in Transnational Cyberspace: The Case For Contracting With Potential Infringers, 35 ColuM. J. TRANSNAT'L L. 619 (1997)).

lï See, e.g., Caspi v. Microsoft Network, L.L.C., 732 A.2d 528 (N.J. Super. Ct. App. Div. 1999) (holding that a forum selection clause contained within an electronic membership contract to which customers must agree before they receive services, was valid and binding). This trend may depend upon the extent to which the courts are willing to monitor click-on contracts for adhesive or abusive aspects, but the trend in U.S. law is to take a relatively unintrusive attitude to forum selection clauses, even in consumer contracts. See Carnival Cruise Lines, Inc. v. Shute, 499 U.S. 585, 595 (1991) (upholding forum selection clause in a standard form consumer contract where there was no indication that the forum was chosen as a means of discouraging the pursuit of legitimate claims or that the agreement had been obtained by fraud or overreaching); Bremen v. Zapata Off-Shore Co., 407 U.S. 1, 15 (1972) (holding that a forum selection clause should be enforced unless the party seeking to set it aside can "clearly show that enforcement would be unreasonable and unjust, or that the clause was invalid for such reasons as fraud or overreaching"). The Uniform Computer Information Transactions Act, adopted by the National Conference of Commissioners on Uniform State Laws in July 1999 , contains provisions on both forum selection and choice of law clauses. See NAT'L CONF. OF COMM'R ON UNIF. ST. LAWS, UNIFORM COMPUTER INFORMATION TRANSACTIONS ACT $\$ \$ 109-10$ (regulating choice of law and forum selection clauses, respectively), available at http://www.law.upenn.edu/bll/ulc/ucita/cital0st.htm. The model Act, which is the remnant of the joint NCCUSL/ALI efforts to draft Article $2 B$ of the UCC, has recently been enacted by Virginia, the first state to do so. Under section $110(\mathrm{a})$, "the parties in their agreement may choose an exclusive judicial forum unless the choice is unreasonable and unjust." NAT'L CONF. OF COMM'R ON UNIF. ST. LAWS, UNIFORM COMPUTER INFORMATION TRANSACTIONS ACT $\$ 110($ a).

${ }^{174}$ The extent to which arbitrators may be likely to dispense with the application of a single national standard and, instead, apply international norms may also be affected by considerations of affinity. Online arbitration of internet disputes may enable arbitrators to discard more easily their national allegiance. That is, to the extent that tribunals have a tendency to do what comes naturally and apply their own law, $c f$. Erwin v. Thomas, 264 Or. 454, 459-60 (1973) (describing application of lex fori in multistate case as doing "what comes naturally"), that tendency may be repressed by the looser national attachments that might come from the use of an international arbitration 
natives that develop, and the extent to which those national laws favor content providers and can reach the conduct of potential defendants. ${ }^{180}$ The calculus will also be affected by whether courts permit parties to provide contractually for rights not available under the default rules of copyright law. ${ }^{181}$ Finally, the outcome will also hinge upon the coherent development of a set of international standards that are sufficiently predictable to allow commercial actors to order their affairs. On this question, the particular internet context may prove more troublesome than international copyright disputes generally; one of the attractions of the internet may be its predictable lack of predictability, and the resistance of users to conformity or regulation. ${ }^{182}$ This should not, however, prove an insuperable obstacle to the application of a copyright lex mercatoria even in the online context, provided that internet-user custom is not the sole desideratum in the recognition and development of international norms. ${ }^{183}$

\section{B. Choice of Law Analysis in Copyright Litigation}

\section{The Territoriality of Copyright Law}

If there remains uncertainty over whether private arbitration might supply an additional impetus to international copyright lawmaking, it would, under traditional analysis, appear quite certain that national court decisions could not provide any such stimulus beyond articulating national policies for international negotiators to consider. Copyright laws operate territorially. ${ }^{184}$ As a general rule, copyright

administrator such as the WIPO Arbitration Center.

${ }^{180}$ See supra note 170 (discussing U.S. cybersquatting legislation).

${ }^{181}$ See ProCD, Inc. v. Zeidenberg, 86 F.3d 1447, 1455 (7th Cir. 1996) (finding that a cause of action to enforce a contractual obligation prohibiting acts of copying permitted by the Copyright Act was not preempted).

${ }^{182}$ See James Boyle, Foucault in Cyberspace: Surveillance, Sovereignty, and Hard-Wired Censors, 66 U. CIN. L. REv. 177, 178-84 (1997) (discussing the characteristics of the internet that make it resistant to state regulation).

${ }^{183}$ For example, under the rules of one online dispute settlement provider, absent party selection of an applicable law, the arbitrator will apply the national law with which the dispute has the greatest connection. But, regardless of whether the choice is made by the parties, the arbitrator shall "take into account the contract and prevailing cyberspace practices." Ginsburg, supra note 55, at 14 (emphasis added) (quoting CYBERTRIBUNAL, BASIC RULES OF CYBERTRIBUNAL art. 17); see also Frank A. Cona, Application of Online Systems in Alternative Dispute Resalution, 45 BUFFALO L. REV. 975, 987 (1997) (describing the now-closed Virtual Magistrate Project).

${ }^{184}$ See Quality King Distribs., Inc. v. L'Anza Research Int'l, Inc., 523 U.S. 135, 154 (1998) (Ginsburg, J., concurring) (citing with approval the proposition that copyright protection is territorial); Subafilms, Ltd. v. MGM-Pathe Communications Co., 24 F.3d 
disputes are litigated in and under the laws of the country in which the act of infringement is alleged to have occurred.

U.S. courts have, however, become involved in international copyright disputes. Copyright law may be territorial, but the exploitation of copyrighted works is increasingly international. Thus, U.S. courts have granted relief in respect of acts of overseas infringement where a predicate act of infringement occurring within the United States enabled further reproduction abroad. ${ }^{185}$ And courts have found claims arising under the U.S. copyright statute-sometimes via the concept of contributory infringement-where the foreign conduct was clearly intended to, and did, have an effect in the United States. ${ }^{186}$

1088, 1095 (9th Cir. 1994) (en banc) (“[T]he United States' copyright laws have no application to extraterritorial infringement ....").

${ }_{1{ }^{5}}$ See, e.g., Los Angeles News Serv. v. Reuters T.V. Int'l, Ltd., 149 F.3d 987 (9th Cir. 1998) (permitting recovery of damages for unauthorized transmission abroad of a work first copied and transmitted without authorization in the United States); Update Art, Inc. v. Modiin Publ'g, Ltd., 843 F.2d 67, 72-73 (2d Cir. 1988) (holding that the court had subject matter jurisdiction over plaintiff's claim for damages arising from the distribution in Israel of copies of a poster made in the United States); Sheldon v. Metro-Goldwyn Pictures Corp., 106 F.2d 45, 52 (2d Cir. 1939) (awarding plaintiff profits from both U.S. and Canadian exhibitions of an "infringing [motion] picture" where a copy of the motion picture had been made in the United States and then shipped to Canada for exhibition), aff $d, 309$ U.S. 390 (1940). Courts applying this theory have not analyzed the question whether the acts abroad were infringing under the foreign law in question. See, e.g., Sheldon, 106 F.2d at 52 ("We need not decide whether the law of those countries where the negatives were exploited recognized the plaintiff's equitable interest."). But of. Filmvideo Releasing Corp. v. Hastings, 668 F.2d 91, 93-94 (2d Cir. 1981) (declining to order delivery up of negatives and prints when it was unclear whether domestic infringer had the right to show the films in question abroad). Courts have, however, been insistent that the U.S. activity truly be a predicate for the foreign acts. See Robert Stigwood Group Ltd. v. O'Reilly, 530 F.2d 1096, 1101 (2d Cir. 1976) (holding that noninfringing rehearsals in the United States were not a predicate for unauthorized live performances in Canada and that thus the Canadian performances should not be included in a calculation of damages under U.S. copyright law); Gaste v. Kaiserman, 683 F. Supp. 63, 65 (S.D.N.Y. 1988) (declining to award damages for unauthorized live performances of a song in France because those performances did not flow from any act of unauthorized reproduction in the United States), aff $d$, 863 F.2d 1061 (2d Cir. 1988).

See, e.g., Armstrong v. Virgin Records, Ltd., 91 F. Supp. 2d 628, 635-36 (S.D.N.Y. 2000) (finding that jurisdiction may exist over the defendant's foreign acts to the extent that the defendant could be liable contributorily or vicariously for subsequent infringement within the United States); Blue Ribbon Pet Prods., Inc. v. Rolf C. Hagen (USA) Corp., 66 F. Supp. 2d 454, 461-63 (E.D.N.X. 1999) (holding that acts in Canada could provide the basis for liability under U.S. copyright law because "a defendant can be liable for contributory infringement, even for acts committed outside the United States, by inducing or contributing to another's infringement occurring in the United States,... provided the defendant knew or should have known that the other would or could reasonably be expected to commit the infringement"); ITSI T.V. Prods., Inc. v. California Auth. of Racing Fairs, 785 F. Supp. 854, 864 (E.D. Cal. 1992) (noting that "it 
Under each of these theories, courts have decided the international copyright dispute by applying U.S. copyright law. ${ }^{187}$ Indeed, the willingness of the U.S. courts to manipulate ${ }^{188}$ these two theories in order to apply U.S. law to international disputes has caused one leading commentator to suggest that effectively "U.S. courts may well favor the lex for in transnational copyright cases." 189 In some respects, any

is possible for a defendant to commit acts outside the United States sufficient to find it contributorily or vicariously liable for acts of infringement committed by others within the United States"), rev'd on other grounds, ITSI T.V. Prods., Inc. v. Agric. Ass'n, 3 F.3d 1289 (9th Cir. 1993); GB Mktg. USA Inc. v. Gerolsteiner Brunnen GmbH \& Co., 782 F. Supp. 763 (W.D.N.Y. 1991) (assuming jurisdiction on a theory of contributory infringement over acts of copying in Germany that were undertaken with the "knowledge and intent" that the infringing products would be exported to the United States by the direct infringer in violation of the copyright owner's importation right); see also Metzke v. May Dept. Stores Co., 878 F. Supp. 756 (W.D. Pa. 1995) (holding that defendant could be liable where it supplied samples of the product at issue to copier in Taiwan if it knew or should have known that unauthorized copies made in Taiwan would be distributed in the United States).

${ }^{187}$ Foreign copyright law was occasionally applied by some courts, without analysis, to issues such as ownership of copyrights. See Itar-Tass Russian News Agency v. Russian Kurier, Inc., 153 F.3d 82, 89 (2d Cir. 1998) (listing cases).

${ }^{188}$ Although the predicate act theory may seem to be an example of a multilateralist philosophy to choice of law in the U.S. courts, localizing the transnational dispute at the point of origin, Jane Ginsburg has noted that U.S. courts "appear to apply it primarily when it justifies the application of U.S. law by U.S. courts." Jane C. Ginsburg, Private International Law Aspects of the Protection of Works and Objects of Related Rights Transmitted Through Digital Networks 39, WIPO Doc. GCPIC/2 (Nov. 30, 1998), available at http://www.wipo.int/eng/meetings/1998/gcpic/pdf/gpic_2.pdf.

${ }^{189}$ Ginsburg, supra note 188, at 39; see also Graeme W. Austin, Domestic Laws and Foreign Rights: Choice of Law in Transnational Copyright Infringement Litigation, 23 COLUM.-VLA J.L. \& ARTS 1, 3 (1999) (noting that "United States courts have employed a number of choice of law strategies to enable application of U.S. copyright law to allegations of copyright infringement based on acts that have occurred abroad"). This may-if only slightly-overstate the case law. U.S. courts have not been uniformly assertive in recent years regarding the application of U.S. law. Recent U.S. case law, both in matters of choice of law and forum non conveniens, suggests that while theoretical bases for extensive applications of U.S. copyright law can be discerned in and extracted from a number of different opinions, some courts have been respectfully cautious. For example, in Subafilms, 24 F.3d at 1095, an en banc panel of the Ninth Circuit overruled its decision of eight years earlier in Peter Starr Prod. Co. v. Twin Continental Films, Inc., 783 F.2d 1440 (9th Cir. 1986), and held that mere authorization in the United States of foreign infringing conduct cannot be actionable under U.S. copyright law because the direct act of infringement abroad was not actionable in the United States. Other courts are divided on whether to follow Subafilms. Compare Armstrong, 91 F. Supp. 2d at 634 (noting repudiation of Peter Starr), and Fun-Damental Too Ltd. v. Gemmy Ind. Corp., 41 U.S.P.Q.2d 1427 (S.D.N.Y. 1996) (following Subafilms), with Expediters Int'l of Washington, Inc. v. Direct Line Cargo Mgmt. Serv., Inc., 995 F. Supp. 468, 477 (D.N.J. 1998) (holding that "the mere authorization of infringing acts abroad constitutes direct infringement and is actionable under United States Copyright Law"), and Curb v. MCA Records, Inc., 898 F. Supp. 586, 595 (M.D. Tenn. 1995) (same). Similarly, in Creative Technology, Ltd. v. Aztech System PTE, Ltd., 61 F.3d 696, 704 
tendency of the U.S. courts too readily to apply U.S. law to transnational disputes may simply reflect what Andreas Lowenfeld called the "public law taboo," namely, the unwillingness of a forum to displace its own public laws or to apply the public laws of another nation. ${ }^{190}$ That taboo rests, however, upon a public/private distinction that is now frail, and in several cases (mostly within the last two years) U.S. courts have entertained complaints alleging acts of copyright infringement under a collection of foreign laws.

(9th Cir. 1995), the Ninth Circuit dismissed on forum non conveniens grounds a copyright infringement case involving U.S. and Singapore copying and deferred instead to the Singaporean courts. See also Murray v. British Broad. Corp., 81 F.3d 287 (2d Cir. 1996) (affirming forum non conveniens dismissal). And in Allarcom Pay T.V. Ltd. v. General Instrument Corp., 69 F.3d 381 (9th Cir. 1995), the Ninth Circuit rejected the argument that U.S. copyright law governed the unauthorized transmission of works from the United States to Canada. This is not to say that the doctrinal basis for more aggressive applications of U.S. law has not been developed; as these scholars note, the bases exist. And the predicate act theory-what some of these scholars call the root copy theory-may present significant temptation in the internet context, where a U.S. copy or U.S. performance should not be hard to find. See infra text accompanying notes 213-14. But the theories have thus far not fully been used by all courts, in part because of the recent internationalization efforts of the executive and Congress. See infra note 228.

See LOWENFELD, supra note 176, at 3-5; see also Philip J. McConnaughay, Reviving the "Public Law Taboo" in International Conflict of Laws, 35 STAN. J. INT'L L. 255, 256 n.2 (1999) (identifying Lowenfeld's 1979 work, Public Law in the Intermational Arena: Conflict of Laws, International Law and Some Suggestions for their Interaction, 163 RECUEIL DES COURS, 311, 322 (1979), as the source of the term).

${ }^{1 ! 1}$ See, e.g., Boosey \& Hawkes Music Publishers, Ltd. v. Walt Disney Co., 145 F.3d 481, 484 (2d Cir. 1998) (reversing district court's dismissal of claims under foreign copyright laws on forum non coveniens grounds); Carell v. Shubert Org., 104 F. Supp. 2d 236, 257-59 (S.D.N.Y. 2000) (permitting claims based on foreign copyright laws to proceed notwithstanding the plaintiff's failure to specify in her complaint the particular countries under whose laws the claims were made); Armstrong, $91 \mathrm{~F}$. Supp. 2d at 637-38 (entertaining claims based on unspecified foreign copyright laws on the basis of diversity jurisdiction and pendent jurisdiction); Frink America, Inc. v. Champion Road Mach., Ltd., 961 F. Supp. 398, 402-05 (N.D.N.Y. 1997) (declining to dismiss claim under Canadian copyright law); London Film Prods. v. Intercont'l Communications, 580 F. Supp. 47, $49-50$ (S.D.N.Y. 1984) (agreeing to hear claims under several foreign copyright laws). But see ITST T.V. Prods., Inc., $785 \mathrm{~F}$. Supp. at 866 (declining to enter the "bramble bush" of foreign copyright law). The English courts have recently recognized that certain foreign copyright claims might be adjudicated before them. See Pearce v. Ove Arup P'ship, [1999] 1 All E.R. 769, 784-804 (C.A. 1999) (hearing claim for infringement of Dutch copyright). This is a consequence of United Kingdom membership in a European convention, the Brussels Convention on Jurisdiction and Enforcement of Judgments in Civil and Commercial Matters. See Convention on Jurisdiction and Enforcement of Judgments in Civil and Commercial Matters, Sept. 27, 1968, 1978 O.J. (L 304) 77, 78-83, 8 I.L.M. 229 (1969), amended by 1990 O.J. (C 189) 2, 3-9, 29 I.L.M. 1417 (1990) (establishing jurisdictional guidelines for countries that are signatories to the Convention). The basic tenets of the Brussels Convention may soon be replicated at the global level under the auspices of the Hague Conference on Pri- 
Yet, even in these cases, each distinct claim was (or would have been) tried under the separate national copyright law of the country where infringement allegedly occurred. ${ }^{192}$ Judicial resort to separate national laws in international litigation reflects the territorial nature of copyright protection. There is no such thing as an international copyright. By virtue of the premise of territoriality underlying international copyright relations, the creation of a copyrighted work results in the grant of a separate copyright under, and according to the principles of, each country recognizing copyright protection. ${ }^{193}$ The international obligation of national treatment ensures that works receive protection in countries other than their country of origin. But that protection is a function of the laws in those other countries, influenced to some extent by the minimum substantive standards required by the Berne Convention and TRIPS.

The Berne Convention embodies these basic principles in Article 5. Article 5(1) provides that:

Authors shall enjoy, in respect of works for which they are protected under this Convention, in countries of the Union other than the country of origin, the rights which their respective laws do now or may hereafter grant to their nationals, as well as the rights specially granted by this

vate International Law. See Preliminary Draft Convention on Jurisdiction and Foreign Judgments in Civil and Commercial Matters (adopted by Special Commission on Oct. 30,1999 ) (proposing rules of private international law regarding inter alia jurisdiction in civil disputes), available at http://www.hcch.net/e/conventions/draft36e.html. The draft Hague Convention addresses both jurisdiction and recognition of judgments: this is intended to permit a compromise under which the European countries would liberalize their recognition policies and the U.S. would limit its more expansive notions of jurisdiction. For an analysis of the convention debate, see Kevin M. Clermont, Jurisdictional Salvation and the Hague Treaty, 85 CORNELL L. REV. 89 (1999). A diplomatic conference to adopt the convention had been scheduled for late 2000 , but the United States indicated its unease with the current draft (which is closely modeled on the Brussels Convention that operates within Europe) and adoption will not occur until 2001 at the earliest. See Jeffrey D. Kovar, Assistant Legal Adviser for Private International Law, U.S. Department of State, Testimony Before the Subcommittee on Courts and Intellectual Property of the Committee on the Judiciary of the House of Representatives (June 29, 2000) (describing major obstacles preventing immediate conclusion of the Convention), available at http://www.house.gov/judiciary/kova0629.htm (last visited Aug. 14, 2000).

${ }^{192}$ See, e.g., Carell, 104 F. Supp. 2d at 258-59 (rejecting claims to apply standards found in international conventions).

${ }^{193}$ See Computer Assocs. Int'I v. Altai, Inc., 126 F.3d 365, 371-72 (2d Cir. 1997) (rejecting a motion for an antisuit injunction preventing the plaintiff from pursuing claims in France for infringement of its French copyright notwithstanding that the defendant had prevailed when similar claims had been brought under U.S. copyright law in a U.S. court). 
Convention. ${ }^{194}$

It is commonly understood that this explicit principle of national treatment "implicates a rule of territoriality." And Article 5(2), which provides that "the extent of protection, as well as the means of redress afforded to the author to protect his rights, shall be governed exclusively by the laws of the country where protection is claimed" is also said to embody (although more enigmatically) the principle of territoriality. ${ }^{196}$

In sum, the principle of territoriality upon which the Berne Convention is founded requires courts to apply national laws even to international disputes. And, to the extent that U.S. courts have been willing to localize an international dispute in a single country, they have invariably localized to the United States and thus have applied U.S. law.

\section{Traditional Approaches to Choice of Law in Copyright}

If public international law establishes the basic framework and environment in which international institutions and states can develop international solutions, ${ }^{197}$ choice of law rules and methodologies arguably do the same in the context of private international litigation. ${ }^{198}$ As noted above, the language of Article 5(2) of the Berne Convention, and the broader principle of national treatment, were widely thought to cement in place a choice of law rule based upon territoriality. ${ }^{199}$

Berne Convention, supra note 15, art. 5(1), 1161 U.N.T.S. at 35.

Subafilms, Ltd. v. MGM-Pathe Communications Co., 24 F.3d 1088, 1097 (9th Cir. 1994) (en banc).

Berne Convention, supra note 15, art. 5(2), 1161 U.N.T.S. at 35. Textually, Article 5(2) could be read to institute a rule of lex fori because the forum is "the country where protection is claimed." But the accepted reading of the provision is that it refers to the country in respect of which protection is claimed-that is, where infringement is alleged to have occurred. See, e.g., Austin, supra note 189, at 2425 (discussing accepted interpretations of Article 5(2)).

114 See Trachtman, supra note 40, at 349-50 ("[P]ublic international law serves the function that a constitution serves in the domestic legal system: it is a fundamental component governing the production of the remainder and of the institutional environment for international organizations and for states.").

${ }^{\text {I'k }}$ Cf. Ginsburg, supra note 3, at 280 (observing that "[c]hoice of law strategies become increasingly important as copyright disputes range over multiple territories").

${ }^{1 *}$ See Creative Tech., Ltd. v. Aztech Sys. PTE, Ltd., 61 F.3d 696, 701 (9th Cir. 1995) (commenting that "national treatment and territoriality are choice of law principles"); Subafilms, 24 F.3d at 1097 (acknowledging the accepted view that although copyright treaties do not discuss choice of law, "the national treatment principle implicates a rule of territoriality," and noting that "the applicable law is the copyright law of the state in which the infringement occurred, not that of the state of which the author 
Many courts and scholars assumed that this simplified copyright choice of law questions ${ }^{200}$-apply the law of the place where the copying or other allegedly infringing act occurred-and thus the issue was rarely litigated. ${ }^{20}$

This illusion has been rudely disturbed by digital technology and global commerce, and copyright choice of law has received increased attention of late both in the literature ${ }^{202}$ and in the courts. ${ }^{203}$ The economic premises underlying the international copyright conventionsnamely, creation and exploitation of copyrighted works nationally and, if internationally, serially on a country by country basis-have be-

is a national or in which the work was first published" (citation omitted)). The Court of Appeals for the Second Circuit, however, has correctly noted that:

[T] he principle of national treatment is really not a conflicts rule at all; it does not direct application of the law of any country. It simply requires that the country in which protection is claimed must treat foreign and domestic authors alike. Whether U.S. copyright law directs U.S. courts to look to foreign or domestic law as to certain issues is irrelevant to national treatment, so long as the scope of protection would be extended equally to foreign and domestic authors.

Itar-Tass Russian News Agency v. Russian Kurier, Inc., 153 F.3d 82, 89 n.8 (2d Cir. 1998).

${ }^{200}$ See 3 PAUL GOLDSTEIN, COPYRIGHT $\$ 16.2$ (Supp. 1999) (providing an overview of the territoriality principle); 4 MELVILLE $B$. NIMMER \& DAVID NIMMER, NIMMER ON COPYRIGHT $\$ 17.05$ (2000) (addressing conflicts in copyright law); $c f$. Reichman \& Samuelson, supra note 25, at $112 \mathrm{n} .279$ ("From a legal perspective, these developments raise daunting problems of conflicts of law, a field that has never found it easy to accommodate intangible property.").

${ }^{201}$ See Itar-Tass, 153 F.3d at 88 ("Choice of law issues in international copyright cases have been largely ignored in the reported decisions and dealt with rather cursorily by most commentators.").

${ }^{202}$ See Austin, supra note 189, at 6 n.15 (listing recent scholarship).

${ }^{203}$ The Itar-Tass court commented that "the Nimmer treatise briefly (and perhaps optimistically) suggests that conflicts issues "have rarely proved troublesome in the law of copyright." Itar-Tass, 153 F.3d at 89 (citation omitted). For other recent cases, see Shaw v. Rizzoli Int'l Publ'g, Inc., 51 U.S.P.Q.2d (BNA) 1097 (S.D.N.Y. 1999) (following Itar-Tass's treatment of choice of law, and finding that the United States was the country with most significant relationship to photographs in question); Bridgeman Art Library Ltd. v. Corel Corp., 25 F. Supp. 2d 421 (S.D.N.Y. 1998) (considering the applicable law governing the issue of copyrightability in a claim of infringement of the copyright in U.K. works), aff'd on reconsideration, 36 F. Supp. 2d 191 (S.D.N.Y. 1999); Cranston Print Works Co. v. J. Mason Prods., 49 U.S.P.Q.2d (BNA) 1669 (S.D.N.Y. 1998) (applying U.S. law to determine the ownership of copyright in design because, applying Itar-Tass, the United States was the place of first publication and hence the country with the closest connection to the work). One European commentator has captured recent developments nicely in the title to a short comment on copyright choice of law issues. See Paul Torremans, Jurisdiction and Choice of Law Issues in United States Intellectual Property Cases: From Dodging the Bullet to Biting It, 3 INTELL. PROP. Q. 372, 373-78 (1999) (discussing choice of law issues related to internet copyright infringement cases). 
come detached from social and economic reality. The place where an act of alleged infringement "occurs" has become difficult to determine in the digital environment; concepts such as "place" of publication or "country of origin" lose meaning in a global and digital world, where geography holds less significance. ${ }^{204}$

Moreover, the range of international copyright cases coming before the courts has resulted in closer attention to the supposedly simple choice of law rule. Thus, in Itar-Tass Russian News Agency v. Russian Kurier, Inc., the Second Circuit noted that international copyright conventions were not self-executing and thus declined to extract a choice of law rule from Article 5(2) of the Berne Convention alone. ${ }^{205}$ Finding no generally applicable rule in the Copyright Act, ${ }^{206}$ the court developed a choice of law rule as a matter of federal common law. ${ }^{207}$ As a threshold matter, the court acknowledged that the conventional statement of the copyright choice of law rule-law of the place of infringement-was too broad, and that different laws may apply to different issues in a copyright litigation. ${ }^{208}$ On the question of copyright ownership, the court rejected a rule-based approach to choice of law, emblematic of the First Restatement of Conflicts, and instead looked to the policy-based approach of the Second Restatement. In particular, the court applied the general test of the Second Restatement, un-

${ }^{2 / 4}$ For a full and insightful discussion of these problems, see Jane C. Ginsburg, Global Use/Territorial Rights: Private International Law Questions of the Global Information Infrastructure, $42 \mathrm{~J}$. COPYRIGHr SOC'Y 318 (1995); Jane C. Ginsburg, Ownership of Electronic Rights and the Private International Law of Copyright, 22 COLUM.VLA J.L. \& ARTS 165 (1998); Jane C. Ginsburg, The Private International Law of Copyright in an Era of Technological Change, 273 RECUEIL DES COURS 239 (1998); see also Geller, supra note 136, at 101 (noting that ${ }^{~}[t]$ here are more and more cases in which it is difficult to localize the origin or the infringement of intellectual property territorially"). But see Goldsmith, supra note 27, at 1201 (arguing that cyberspace presents conflicts issues that are no more difficult from those that occur outside cyberspace).

2153 F.3d at $89-90$.

Section $104 A$ (b) of the Copyright Act, which restored copyright in certain works that were in the public domain because of noncompliance with formalities of U.S. law, does provide that ownership of copyright in a restored work vests in the author or initial rightholder of the work as determined by the law of the source country of the work," which the statute then defines. 17 U.S.C. $\$ 104 A$ (b) (1994). But the court refused to draw general significance from this provision. See Itar-Tass, 153 F.3d at $90 \mathrm{n} .10$ (noting that section $104 \mathrm{~A}$ (b) neither establishes a general copyright conflicts rule nor suggests that it is an exception to any general conflicts rule).

${ }^{217}$ As this suggests, the federal courts have significant latitude to develop an approach to choice of law in international copyright cases. See discussion infra Part III.B.3 (proposing a new approach to choice of law in international copyright cases); see also infra note 342 (discussing means of implementing this proposal).

${ }^{2}$ The court thus recognized the doctrine of dêpeçage. See sources cited supra note 13 (outlining the doctrine). 
der which the law of the place with the most significant relationship to the parties and the transaction is typically applied. ${ }^{209}$ Swayed in particular by the nationality of the authors, and the place of first publication, both of which were Russian, the court applied Russian law to determine the ownership of the copyright. ${ }^{210}$ On the separate question of which law applied to determine questions of "infringement," the court concluded that the lex loci delicti would apply, whether as a fixed rule (akin to the First Restatement) or as part of a broader interest analysis (more similar to the Second Restatement). ${ }^{211}$

Although the Itar-Tass opinion is a fuller analysis of copyright choice of law questions than we have seen before in U.S. courts and is probably correct on the merits, its conflicts analysis remains somewhat rooted in methodologies that may prove unhelpful in more complex international (and especially) digital cases. In particular, although the court nominally adopted the flexible policy-based approach of the Second Restatement, it made its determination using nothing more than a barren listing of points of attachment. ${ }^{212}$ Moreover, the points

${ }^{209}$ See RESTATEMENT (SECOND) OF CONFLICTS OF LAWS $\$ \$ 6,145,222$ (1971) (articulating the "most significant relationship" test and listing the choice of law principles according to which courts should determine the place with the most significant relationship to the dispute).

${ }^{210}$ See Itar-Tass, 153 F.3d at 90-91 (following "law of the state with 'the most significant relationship' to the property and the parties" (citation omitted)).

${ }^{211}$ The attraction of the law of the most significant relationship has been noted by several prominent scholars. See, e.g., Ginsburg, supra note 188, at 38 (supporting application of U.S. law to U.S.-based foreign distribution because the U.S. would be the country "with the 'closest relationship' to the resulting harm"); see also CONSEIL. D'ETAT, INTERNET ET RÉSEAUX NUMÉRIQUES 148-51 (1998) (quoted in Ginsburg, supra note 188 , at $38 \mathrm{n} .128$ ). Each of these scholars or policymakers would, however, in a fashion consistent with different provisions of the Second Restatement, suggest points of attachment that would presumptively be the place with the most significant relationship. See CONSEIL D'ETAT, supra, at 148-51 (suggesting that the country with the closest relationship is the principal place/residence of the "uploading entity when that country is a member if the EU," and thus has defined levels of protection). In her most recent work, Professor Ginsburg has refined her proposed choice of law applicable to infringement questions to a hierarchy of possibilities, using compliance with international copyright standards as a necessary predicate for the application of any law, and leaving a residual opportunity for the parties (if subjected to the lex fori) to show that the domestic law of the place where the infringement occurred is more or less protective than the forum. See Ginsburg, supra note 188, at 45 (proposing application of the law of the place where the server hosts the allegedly infringing content, provided that law is Berne-compliant, absent which, the law of the place of residence of the website operator, provided that that law is Berne-compliant, absent which, the lex fori, provided that that law is Berne-compliant). This approach is immensely flexible and very proauthor, and it will clearly require national courts to interpret substantive international copyright standards in order to implement the proposed choice of law inquiry.

${ }^{212}$ This is a criticism leveled at many judicial applications of Second Restatement 
of attachment that appealed to the court, namely nationality and place of publication, may come to say little about the respective prescriptive claims of interested states in more complex cases. Similarly, the rule of lex loci delicti, if taken as a fixed rule rather than the conclusion of an analysis of governmental interests, may provide little guidance (or too many loci delicti) in a digital world where, for example, publication may occur simultaneously in a number of countries. ${ }^{213}$ And, by manipulation of the theories discussed above and under prevailing copyright doctrine, ${ }^{214}$ these places can easily be interpreted, in most cases, to include the United States. As the U.S. Supreme Court cautioned almost half a century ago:

[I]n dealing with international commerce we cannot be unmindful of the necessity for mutual forbearance if retaliations are to be avoided; nor should we forget that any contact which we hold sufficient to warrant application of our law to a foreign transaction will logically be as strong a

analysis in purely domestic cases. See William L. Reynolds, Legal Process and Choice of Law, 56 MD. L. REv. 1371, 1388-89 (1997) (summarizing scholarly criticisms of the Second Restatement); Jeffrey M. Shaman, The Vicissitudes of Choice of Law: The Restatement (First, Second) and Interest Analysis, 45 BUFF. L. REV. 329, 359-60 (1997) (commenting that contacts are often "counted up ... at most with conclusory and arbitrary pronouncements concerning their relative value"); see also James A. Meschewski, Choice of Law in Alaska: A Survival Guide for Using the Second Restatement, 16 ALASKA L. REV. 1, 19 (1999) (complaining that lack of guidance prevents any effective restraint on judicial decisionmaking and results in conclusory statement of the most relevant contacts).

${ }^{213}$ The problems raised by copyright infringement via digital distribution bear some parallel to multistate defamation claims, for which U.S. courts have largely adopted the single publication rule. Under this rule, the plaintiff may sue in a single court (where jurisdiction is proper) for damages sustained in any state where damage was suffered. See RESTATEMENT (SECOND) OF TORTS § 577A (1977) (outlining the single publication rule and its justifications). While this does not of itself avoid problems of choice of law, see RESTATEMENT (SECOND) OF CONFLICT OF LAWS $\$ 150$ (1971) (articulating choice of law rules in multistate defamation cases), the injection of federal constitutional issues into defamation law, see New York Times Co. v. Sullivan, 376 U.S. 254 (1964) (holding that the First Amendment requires public figure plaintiffs in defamation cases to establish actual malice on the part of the defendant), has in any event resulted in the effective federalization of large parts of state defamation law. $C f$. James R. Pielemeier, Constitutional Limitations on Choice of Law: The Special Case of Multistate Defamation, 133 U. PA. L. REv. 381, 413 (1985) (arguing that a permissive choice of law rule in multistate defamation cases might effectively federalize state defamation laws). Moreover, the differences between state defamation laws within the United States are probably less significant than the differences that exist between different national copyright laws. But of. Wells v. Liddy, 186 F.3d 505, 525 (4th Cir. 1999) (deciding to apply the common law standards of the Second Restatement of Torts to determine whether a speech aboard a cruise ship at sea was defamatory because the diversity of state laws would impair the principles of uniformity and simplicity underlying federal admiralty law).

${ }^{214}$ See infra note 291. 
warrant for a foreign country to apply its law to an American transaction. ${ }^{215}$

An alternative approach to the uncertainty or overinclusiveness that the Itar-Tass analysis might generate in a more complex or digital environment has been developed in the European Union. Under this approach, found in the EU Cable and Satellite Directive and the socalled E-Commerce Directive, the EU designates a single law that will apply to particular satellite and online issues. Thus, in the Cable and Satellite Directive, the copyright law of the country of the uplink applies in the event of a dispute. ${ }^{216}$ The E-Commerce Directive subjects information society service providers in the EU to defined regulatory laws of only the country where the service provider is "established."217

${ }^{215}$ Lauritzen v. Larsen, 345 U.S. 571, 582 (1953).

${ }^{216}$ See Cable and Satellite Directive, supra note 84, art. 1(2)(b) (defining the act of communication to the public). This approach is largely motivated by considerations of practicality and simplification, see id. recitals 5-7 (identifying uncertainties about applicable law as motivation for the directive), but can be justified under Article 5(2) of the Berne Convention by treating the act of "communication to the public" as occurring only in the country from which a signal originates. Previously, the majority approach throughout Europe was to find that an unauthorized communication to the public occurred at the many places of receipt of the signal. See, e.g., Re Cross-Border Copyright in Television Works [1992] E.C.C. 456, 468-69 (1991) (Aus.) (finding unauthorized communication occurred in all countries of reception). U.S. courts have been inconsistent in their treatment of where to localize satellite transmissions. Compare Allarcom Pay Television, Ltd. v. Gen. Instrument Corp., 69 F.3d 381, 387 (9th Cir. 1995) (holding, for purposes of federal preemption analysis, that any infringement only occurs at the place of receipt of the signal, and thus finding that unauthorized transmission from United States to Canada implicated rights only under Canadian law), with NFL v. Primetime 24 Joint Venture, 211 F.3d 10, 13 (2d Cir. 2000) (rejecting Allarcom and finding that performance also occurs at the place of initiation of the signal in the United States). The trend in the United States appears to favor finding acts implicating the copyright owner's performance rights at every "step in the process by which a protected work wends its way to its audience." David v. Showtime/The Movie Channel, Inc., 697 F. Supp. 752, 759 (S.D.N.Y. 1988); see also NFL, 211 F.3d at 11-12 (reciting case law on liability of intermediate carriers). In the multinational context, this approach widely extends the reach of U.S. copyright law.

${ }^{217}$ See Council Directive 2000/31/EC on Certain Legal Aspects of Information Society Services, in Particular, Electronic Commerce, in the Internal Market, 2000 O.J. (L 178), recital $22 \&$ art. 3(1)-(2) [hereinafter E-Commerce Directive] (adopting a rule that, with respect to a set of listed legal obligations and issues, "information society services should in principle be subject to the law of the Member State in which the service provider is established" and prohibiting member states from seeking to regulate such services when offered by a provider established elsewhere in the EU). The Directive does not, however, automatically adopt the place of the server as the place of establishment. See id. recital 19 (providing several principles by which to identify "[t]he place at which a service provider is established" but noting that the "place of establishment of a company providing services via an Internet website is not the place at which the technology supporting its website is located or the place at which its web- 
Several scholars have considered whether under such an approach one could designate, for example, the law of the place of the server as the law applicable to any copyright dispute resulting from online distribution. ${ }^{218}$ The rules thus identified would then be extended to the full extent of the multinational claim under a version of the predicate act theory used by U.S. courts (this version sometimes being referred to as the "nerve center" theory). ${ }^{219}$ Absent this extension, the putative plaintiff would still be able-and, more importantly, still be required - to bring suit in, or under the laws of, each country of alleged infringement.

The use of a pragmatically selected state of constancy has longstanding antecedents. In maritime cases, for example, the U.S. Supreme Court has acknowledged the value of applying the constant law of the flag in cases where ships pass through many territorial waters. ${ }^{220}$

site is accessible," but rather the "place where it pursues its economic activity"); $c f$. Robert L. Hoegle \& Christopher P. Boam, The Internet and Jurisdiction: International Principles Emerge but Confrontation Loams, 3 J. WORLD. INTELL. PROP. 31, 45-46 (2000) (interpreting the country of origin rule as effectively imposing a rule of country of customer"). It also does not purport to establish general choice of law rules, see E-Commerce Directive, supra, recital 23 ("This Directive neither aims to establish additional rules on private international law relating to conflicts of law [or jurisdiction]."), and intellectual property laws are expressly excluded from the scope of this provision of the Directive. See id. art. 3(3) \& Annex (noting the fields not covered by the Directive). In earlier communications, the Commission expressed concern about extending the approach of the Satellite Directive to the internet context, notwithstanding the attraction of simplicity, because (unlike with satellite transmissions) it may be difficult to identify the single point of origin, and because the lack of general harmonization of copyright law might encourage copyright havens. See Proposal for a European Parliament and Council Directive on the harmonization of certain aspects of copyright and related rights in the Information Society, COM(97)628 final at 12 (discussing opposition to the adoption of a country of origin choice of law rule in the case of digital transmissions).

${ }^{21 K}$ See Jane C. Ginsburg, Copyright Without Borders? Choice of Forum and Choice of Law for Copynight Infringement in Cyberspace, 15 CARDOZO ARTS \& ENT. L.J. 153, 173 (1997) (opining that typically "the court should either apply the law of the place of the server or of the defendant's domicile"); Jane C. Ginsburg, The Cyberian Captivity of Copyright: Territoriality and Authors' Rights in a Netwoned World, 15 SANTA CLARA COMPUTER \& HIGH TECH. L.J. 347, 359 (1999) [hereinafter Ginsburg, Cyberian Captivity] (noting caveats).

${ }^{219}$ See, e.g., Jane C. Ginsburg, Extraterritoriality and Multiterritoriality in Copyright Infringement, 37 VA. J. INT'L L. 587, 600-02 (1997) (discussing "nerve center" theories); Ginsburg, supra note 3, at 283-84 (discussing this argument for adjudication under a single law). But see Austin, supra note 189, at 13-28 (arguing against such an approach).

22" See Lauritzen, 345 U.S. at 584 ("[T]he territorial standard is so unfitted to an enterprise conducted under many territorial rules ... that it usually is modified by the more constant law of the flag."). The reasons for this rule are largely pragmatic, although effectuated (as were many pragmatic common law rules) by a fiction, namely, 
This approach of pragmatic localization may be problematic, however, because it might encourage a race to the bottom in order to attract particular business. Thus, in the two EU Directives adopting this approach, the choice of law rule is accompanied by significant harmonization of substantive rules governing satellite transmission of copyrighted works, and consumer protection laws applicable to service providers, respectively. Similarly, scholars seeking to localize an international copyright dispute at a particular point, such as the place of the server, have incorporated in their proposed tests a range of caveats to prevent such "races" from occurring. ${ }^{221}$ But these (necessary) caveats inevitably detract from the gains in certainty provided by the localizing rule. If certainty and predictability are the reasons for adopting an arbitrary and inflexible rule, this approach becomes less attractive when the principal advantages are imperiled. ${ }^{222}$

Courts and scholars addressing this issue have done so almost entirely from within the confines of accepted and broadly-applied conflicts doctrines. That is, although there is disagreement over whether a transnational dispute should be analyzed under a single law using a version of the predicate act theory or under the separate laws of each

that the ship is part of the territory whose flag it flies even when within the territorial limits of another sovereign. The Supreme Court has noted:

Some authorities reject, as a rather mischievous fiction, the doctrine that a ship is constructively a floating part of the flag-state, but apply the law of the flag on the pragmatic basis that there must be some law on shipboard, that it cannot change at every change of waters, and no experience shows a better rule than that of the state that owns her.

Id. at 585 . The same pragmatic arguments, effectuated by a similar (though perhaps more real) fiction, might be considered in cyberspace.

${ }_{221}$ See, e.g., Ginsburg, supra note 188 , at 45 (providing alternative tests to be used if a country's copyright laws are not adequate).

${ }_{222}$ One could repursue certainty by providing for the invariable application of the higher level of protection. Although this will embed a substantive bias, not all scholars are troubled by such a device. Professor Ginsburg, for example, has hinted that, in light of the purpose of the Berne Convention, see Berne Convention, supra note 15 , pmbl., cl. 1, 1161 U.N.T.S. at 31 (articulating the purpose of the Convention as "to protect, in as effective and uniform a manner as possible, the rights of authors in their literary and artistic works," (emphasis added)), choice of law determinations in treaty countries "should be guided by the principle of favor auctoris: when in doubt, follow the conflicts analysis that will yield an author-favorable outcome." Ginsburg, supra note 188 , at 33 n.109. This approach would fit within the methodology of several conflicts scholars in the United States discussing noncopyright problems, namely to embed substantive policy preferences explicitly in the choice of law rules. See, e.g., RUSSELL J. WEINTRAUB, COMMENTARY ON THE CONFLICT OF LAWS 359-60 (3d ed. 1986) (discussing pro-plaintiff conflicts rules in tort cases); see also RUSSEIL J. WEINTRAUB, COMMENTARY ON THE CONFLICT OF LAWS 356 (4th ed. 2001) (explaining the scope of his pro-plaintiff approach). 
country in which an infringement occurs, ${ }^{223}$ most courts and scholars have either proposed adoption of localizing rules reflecting the traditional U.S. approach to choice of law embodied in the First Restatement of Conflicts, or have endorsed a variant of the policy-based analysis increasingly dominant in contemporary conflicts analysis and found in the Second Restatement of Conflicts. ${ }^{224}$

22:5 Territorialist scholars have argued that the basic philosophy of the Berne Convention requires that the law of every country in which infringement is alleged must separately be applied to the unauthorized acts. See, e.g., Austin, supra note 189, at 4 (arguing that "the preferable approach is for domestic courts to apply the relevant foreign laws to each instance of foreign infringement"); see also Curtis A. Bradley, Territorial Intellectual Property Rights in an Age of Globalism, 37 VA. J. INT'L L. 505, 549 (1997) (criticizing application of U.S. law to foreign acts on the grounds that it destroys the room for diversity implicit in the Berne approach); André Lucas, Aspects de Droit International Privé de la Protection d'Oeuvres de Droits Connexes Transmis Par Réseaux Numériques Mondiaux [Private International Law Aspects of the Protection of Works and Objects of Related Rights Transferred Through Digital Networks] 29, 34-35, WIPO Doc. GCPIC/1 (Nov. 25, 1998) (noting that " $[t]$ here is nothing illogical (even if it less simple) in a single act of exploitation having its consequences in several countries being governed in a distributive manner by the laws of those countries," but concluding that, if departure from such an approach were warranted, "the only solution is ... the cumulative application of the law of the country of emission and the laws of the various countries of reception"), at http://www.wipo.org. There are two separate components to this debate. First, can a single law be applied to govern similar (or, in the internet context, the same) conduct that occurs in several jurisdictions; and, second, even if a series of different laws must be applied, can these claims be brought in a single court? Failure to answer each of these questions in the affirmative will impose significant costs and uncertainties on the international dissemination of copyrighted works. Permitting the assertion of different foreign claims in a single proceeding would ease the difficulties, but the difference would be a matter of degree. In any event, U.S. courts are divided as to whether they should even hear foreign copyright infringement claims. See supra note 191 (listing competing case law). Absent such a willingness, strict adherence to territoriality would cause inefficient serial national litigation of almost identical issues. See Computer Assocs. Int'l, Inc. v. Altai, Inc. 126 F.3d 365, $371-72$ (2d Cir. 1997) (declining to enjoin losing party in U.S. copyright infringement litigation from pursuing parallel claim before French courts for infringement of French copyright); see also Peter Nicolas, Comment, The Use of Preclusion Doctrine, Antisuit Injunctions, and Forum Non Conveniens Dismissals in Transnational Intellectual Property Litigation, 40 VA. J. INT'L L. 331, 365-75 (1999) (discussing the use of antisuit injunctions in multinational intellectual property litigation). It is perhaps because of this that some territorialist theorists devote significant time to explaining why U.S. courts should be willing to entertain foreign copyright claims. See, e.g., Austin, supra note 189, at 28-46 (arguing for domestic application of foreign laws).

Other writers appear keen to aroid the particular problems of cyberspace by recognizing cyberspace as a separate jurisdiction giving rise to its own set of substantive laws. See Hardy, supra note 166 , at 1052 (commenting favorably on the development of virtual courts formed by cyberspace users); Johnson \& Post, supra note 166, at 1378-81 (arguing for the development of a body of rules for the new "place" of cyberspace apart from national laws). Although seemingly radical in result, this approach fits within existing choice of law philosophy; it finds solution in the recognition of an addi- 
The difficulties presented suggest the need for a rethinking of copyright law in the digital environment where copyright disputes are inherently international. But the lessons of such an inquiry need not be limited to digital cases. The problems of cyberspace bring these questions into sharper focus, and it is there that they appear most acute. But the cyber-revolution merely highlights problems endemic to internationalization, which must be confronted more generally. As I explain below, a different approach to choice of law in international copyright cases-whether digitally based or not-may both offer better solutions to international disputes and make a positive contribution to the internationalization of copyright law.

\section{A New Approach to Choice of Law in International Copyright Cases: The Substantive Law Method}

In this Part, I propose a new approach to choice of law in international copyright cases. ${ }^{226}$ Under this approach, which stakes a conscious claim to be part of the substantive law method, ${ }^{227}$ a court faced

tional sovereign, but even here the approach is to identify a single sovereign (under this theory, the cybersovereign) according to whose laws the multinational dispute will be resolved. At this point, I should distinguish myself from these commentators, whom Jack Goldsmith has called "regulation skeptics." Goldsmith, supra note 27, at 1199. Regulation skeptics argue against state regulation of cyberspace both descriptively and normatively, relying in each instance on the geographic ubiquity of cyberspace to press their claim. That is, they contend that the borderless nature of cyberspace undermines both the effectiveness and legitimacy of attempts at national regulation; for regulation to work, and for it to be accepted, it must derive from the activities of cyberspace participants. See Johnson \& Post, supra note 166, at 1372-75 (rejecting the legitimacy or practicability of territorial regulation and suggesting that the strongest claim to regulate online activities rests with participants in cyberspace). I join in the critique, offered by Goldsmith and others, that this analysis draws too clear a line between cyberspace and the offline environment. To be sure, cyberspace transactions have transnational effects, but those effects frequently are felt in offline space. Just as inevitable multinational spillover effects from cyberspace transactions undermine exclusive regulation by a single national norm, so too the inevitable spillover effects into the analog world undermine the claim of exclusive cyberspace self-regulation.

${ }_{225}$ It is indeed the great achievement of [the] Internet, after satellites, to have created an obligation to rediscover the international aspects of this discipline, too long masked, by overshooting the timid territorialism .... To quote the words of Batiffol, it is vain to wish to remove the problems of conflict of laws on the grounds that they are too complex, since reality will take upon itself the task of demonstrating that problems cannot be resolved by ignoring them if they are real problems.

Lucas, supra note 223, at 5.

${ }^{226}$ An argument exists that this method should apply to all international disputes, whether involving copyright law or otherwise, but that issue is beyond the scope of the current Article.

${ }_{227}$ For a discussion of the leading historical schools of choice of law thought, see 
with an international copyright dispute would not necessarily apply the copyright law of a single state to the contested issues. Instead, it would consider whether the international dimension implicated policies of other states or the international copyright system, ${ }^{228}$ and develop (and apply) a substantive rule of copyright law that best effectuates this range of policies.

\section{a. Historical and Scholarly Support}

In recent years, a few conflicts scholars have hinted at (without fully developing) the idea that judges should develop special substantive rules for multistate cases. The strongest suggestion came one quarter of a century ago in a short comment that Professor Arthur von Mehren wrote for the Harvard Law Review based upon a report prepared for the Congress of the International Academy of Comparative Law meeting in Tehran in $1974 .{ }^{229}$ Other indications of support for a substantive law approach can be found in the writings of Friedrich Juenger ${ }^{23 *}$ and Luther McDougal. ${ }^{231}$ As both Juenger and McDougal

Symeon C. Symeonides, General Report, in PRIVATE INTERNATIONAL LAW AT THE END OF THE 20TH CENTURY: PROGRESS OR REGRESS? 9-21 (Symeon Symeonides ed., 2000) (describing the schools of multilateralism, unilateralism, and substantivism). Unlike unilateralism or multilateralism, the substantive law approach is not truly conflictual in nature, seeking as it does to find compromise over conflict.

${ }^{22 x}$ Courts in the United States have made reference to the recent bout of public international copyright lawmaking in adjudicating copyright cases, but these references have largely been made to support deference to treaty negotiations by the executive branch and thus to limit judicial forays into international copyright questions. See, e.g., Creative Tech., Ltd. v. Aztech Sys. PTE, Ltd., 61 F.3d 696, 700-03 (9th Cir. 1995) (referencing the Berne and Universal Copyright Conventions in justifying dismissal of an international copyright dispute on grounds of forum non conveniens); Subafilms, Ltd. v. MGM-Pathe Communications Co., 24 F.3d 1088, 1098 n.16 (9th Cir. 1994) (en banc) (noting the deleterious effect of applying U.S. copyright law to domestic authorization of allegedly unauthorized acts abroad in light of Berne accession and TRIPS negotiations).

¿24 See Arthur Taylor von Mehren, Special Substantive Rules for Multistate Problems: Their Role and Significance in Contemporary Choice of Law Methodology, 88 HARV. L. REV. 347, 357 (1974) [hereinafter von Mehren, Special Substantive Rules] (noting that the substantive rule approach raises the question "whether one should, in handling the choice-af-law problem, work from beginning with a fundamental distinction between situations and transactions that can, and those that cannot, appropriately be localized, allocating regulation of the former to a domestic law and developing special multijurisdictional rules for the latter"); see also Arthur Taylor von Mehren, Choice of Law and the Problem of Justice, LAW \& CONTEMP. PROBS., Spring 1997, at 27, 38-40 (suggesting circumstances in which conflicts of law might best be resolved by compromise of the values of the different states involved).

¿**it See Friedrich K. JUENGER, ChOICE OF LAW AND MULTISTATE JUSTICE 233-37 (1993) [hereinafter JUENGER, CHOICE OF LAw] (supporting the substantive law approach and explaining why it has not been universally adopted); Friedrich $\mathrm{K}$. Juenger, 
explain, there are historical antecedents for such an approach that reach as far back as the Roman Empire. ${ }^{232}$ But these bodies of law, such as the lex mercatoria discussed above, ${ }^{233}$ which permitted courts to avoid choice of law questions, declined in significance with the rise of nation-states and with positivistic demands for a clear connection between law and a sovereign. ${ }^{234}$ The relative decline of the nation-state ${ }^{235}$

Mass Disasters and the Conflict of Laws, 1989 U. ILL. L. REV. 105, 126 (arguing for the substantive law approach in mass tort cases); Friedrich $\mathrm{K}$ Juenger, The Need for a Comparative Approach to Choice-of-Law Problems, 73 TUL. L. REv. 1309, 1331-32 (1999) [hereinafter Juenger, Comparative Approach] ("The substantive law approach ... merits further exploration precisely because it is at loggerheads with fundamental tenets held dear by traditionalists."); see also Friedrich K. Juenger, American Conflicts Scholarship and the New Law Merchant, 28 VAND. J. TRANSNAT'L L. 487, 490-92 (1995) (identifying other scholars who support a substantive law approach).

${ }^{231}$ See Luther L. McDougal, III, "Private" International Law: Ius Gentium Versus Choice of Law Rules or Approaches, 38 AM. J. COMP. L. 521, 536-37 (1990) (arguing that "in many instances the best way to take appropriate account of substantive policies is to do so directly through the development and application of transnational laws" rather than by application of traditional choice of law rules). Interestingly, all three of these scholars can fairly be called scholars of comparative law. The report upon which von Mehren based his article drew from ten different national reports on similar issues in different countries, see von Mehren, Special Substantive Rules, supra note 229, at 347 n.* (listing the national reports), and both Juenger and McDougal make extensive reference to comparative and historical sources in their work.

${ }^{232}$ See JUENGER, CHOICE OF LAW, supra note 230, at 8-10 (discussing the development of the ius gentium by the praetor peregrinus, starting around 242 B.C.).

${ }^{233}$ See supra text accompanying notes 165-66. Courts in the United States currently do apply international standards in certain narrow contexts. See M.O. Chibundu, Making Customary International Law Through Municipal Adjudication: A Structural Inquiny, 39 VA. J. INT'L L. 1069, 1080-92 (1999) (discussing the Alien Tort Claims Act, 28 U.S.C. $\S 1350$ (1994), which creates a cause of action for aliens in the United States based upon violations of the law of nations); Van Alstine, supra note 5, at 761-91 (suggesting that the Convention on the International Sale of Goods calls for the dynamic application of its international standards, such as the requirement of good faith, in adjudicating disputes within its scope). As with the approach proposed in this Article, these international standards are applied by national courts. Thus, although these are, as regards their formation, "universal customary laws tied to no particular sovereign authority," Goldsmith, supra note 27 , at 1206 , their application by courts is subject to monitoring by different national legislatures that could no doubt direct their national courts to apply different principles to such disputes. And different national courts might interpret these so-called "universal" laws differently without recourse to a centralized adjudicatory body to resolve such differences. Thus, any detachment between these laws and national sovereigns should not be overstated.

${ }^{234}$ See McDougal, supra note 231, at 522, 534 (linking the decline of ius commune to nineteenth century codification of law by nation states); Juenger, Comparative Approach, supra note 230, at 1318-19 (noting positivist critique of supranational rules).

${ }_{235}$ See Robert Wright, Continental Drift, NEW REPUBLIC, Jan. 17, 2000, at 18 (considering the emergence of a world government based on global economic institutions). For two provocative analyses of the effect that the internet is likely to have on the nation-state, compare Henry H. Perritt, Jr., The Internet as a Threat to Sovereignty? Thoughts on the Internet's Role in Strengthening National and Global Governance, 5 IND. J. GLOBAL 
may perhaps sound an appropriate clarion call for their reconsideration.

\section{b. The Basic Approach \\ i. Theoretical Basis}

Although von Mehren was writing in part about the development of special substantive rules in the domestic multistate context, the explicit use of this method in internal U.S. multistate cases has been rare. Judge Jack Weinstein effectively used the substantive law method in fashioning a solution to the Agent Orange mass torts litigation. ${ }^{236}$ Recently, though, a panel of the Seventh Circuit in In re Rhone-Poulenc Rohrer, Inc. rebuffed efforts by a district court judge to apply a common standard of negligence to a mass tort case involving parties from different states (whose tort claims were, under traditional choice of law analysis, governed by different laws). ${ }^{237}$ This would, according to the Seventh Circuit, violate principles of federalism given expression by the Supreme Court in Erie v. Tompkins. ${ }^{238}$ And, to be sure, this approach bears more than a passing resemblance to the methodology of Swift $v$. Tyson (an opinion authored, perhaps symbolically, by the father of American conflicts law, Joseph Story). ${ }^{239}$

Even accepting the legitimacy of Erie-style federalism questions in the domestic context, the resolution of multistate conflicts via application of the substantive law method may be of less concern in the international setting. The principles of federalism are no restraint on the federal courts in international copyright cases, ${ }^{240}$ and the parallel

LEGAL STUD. 423 (1998) (arguing that the internet may strengthen legitimate national and international governance), with David G. Post, The "Unsettled Paradox": The Internet, the State, and the Consent of the Governed, 5 IND. J. GLOBAL LEGAI STUD. 521 (1998) (discussing how the internet erodes physical boundaries between states and unleashes the promise of "popular sovereignty").

${ }_{2 * 4}$ See In re "Agent Orange" Prod. Liab. Litig., 580 F. Supp. 690, 696-99 (E.D.N.Y. 1984) (justifying the development of a "national consensus law" on issues in multistate product liability class action); see also Jack B. Weinstein, Mass Tort Jurisdiction and Choice of Law in a Multinational World Communicating by Extra-Terrestrial Satellites, 36 WILLAMETTE L. REV. (forthcoming 2001).

${ }_{2 \times 7}$ In re Rhone-Poulenc Rohrer, Inc., 51 F.3d 1293 (7th Gir. 1995).

Erie R.R. v. Tompkins, 304 U.S. 64 (1938) (holding that a federal court sitting in diversity jurisdiction must apply state law as determined by the state's highest court).

$2 *$ Swift v. Tyson, 41 U.S. (16 Pet.) 1 (1842) (holding that a federal court exercising diversity jurisdiction should apply general federal common law).

24: Federal district courts are granted exclusive jurisdiction over cases arising under the copyright laws, and all state causes of action granting rights equivalent to copyright to subject matter within the scope of copyright are expressly preempted. See 17 U.S.C. 
to Swift v. Tyson is less compelling structurally as well as doctrinally. The domestic parallel is not a federal court constructing general federal law in place of applicable rules of the sovereign states (i.e., Swift). Rather, it is a state court deciding a case not simply by the application of the substantive rules developed for its own internal disputes, but according to a set of broader considerations including but not limited to its own domestic rules. The domestic analogy would thus be that a state court may consider norms from other states and institutions in fashioning a rule applicable to the different factual setting of a multistate (i.e., not purely local) dispute. This analysis of the hypothetical domestic parallel highlights an important aspect of the substantive law method when transferred to the international level: the sovereign nation-state retains control of the formation of the special substantive international rule because it is a rule of national law created for an international setting.

Each national legal system embodies, and seeks to effectuate, a set of values held by those over whom the legal system exercises control (or at least, less idealistically, by those with an effective voice in the creation of that law). Choice of law rules are no more than another set of rules by which that same legal system implements the values it wishes furthered when conduct to be adjudicated in its courts touches the interests of another nation. ${ }^{241}$ Determining the choice of law rule that a legal system follows, therefore, is simply a sovereign choice as to the values that one prioritizes in an international or multistate setting. Judge Posner, in Rhone-Poulenc, chided the district court judge for an approach that would require jury instructions to be given in legal Esperanto. $^{242}$ But the critique is somewhat less withering when the state in question freely decides that it wishes Esperanto to be its vernacular of choice.

But why should a court wish to develop, through choice of law

$\$ 301$ (1994) (preempting state causes of action granting rights equivalent to copyright to subject matter within the general scope of copyright); 28 U.S.C. $\$ 1338$ (a) (1994 \& Supp. IV 1998) (giving the district courts original jurisdiction over patent, trademark, and copyright cases).

${ }^{241}$ In explaining his theory of comparative impairment, William F. Baxter distinguished between "internal" and "external" governmental objectives. See William F. Baxter, Choice of Law and the Federal System, 16 STAN. L. REV. 1, 17-18 (1963). A state's resolution of conflicting interests in domestic contexts reflected its internal objectives, while external objectives were defined as "the objectives of each state to make effective, in all situations involving persons as to whom it has responsibility for legal ordering, that resolution of contending private interests the state has made for local purposes." Id. at 17.

${ }^{242}$ See Rhone-Poulenc, 51 F.3d at 1300 (concluding that it would be impossible to merge the negligence standards of fifty states into one jury instruction). 
analysis, such substantive rules of copyright law applying to multinational disputes? Multilateralist theories, such as those articulated by Story and Beale, ${ }^{243}$ and reflected in the first Restatement of Conflicts, emphasized avoidance of forum shopping as a central goal of choice of law rules. Every legal relation or event, so the theory went, could logically be assigned to a single state. As realism broke down the formalistic pretenses of the multilateralist philosophies, ensuring apt results assumed greater prominence in choice of law thinking (at least in the United States, and to a lesser extent in Europe). In the United States, this took the form of resurgent unilateralism, espoused most forcefully by Brainerd Currie ${ }^{244}$ and reflected in the eclectic analytical tools of the Second Restatement of Conflicts in 1971..$^{245}$ Von Mehren saw the substantive law method as a means of reconciling and accommodating these two competing concerns of choice of law theory, namely, avoidance of forum shopping and aptness of results. ${ }^{246}$

I do not take issue either with this rationale or with the suggestion that the substantive law method can further such an accommodation. But $\mathrm{I}$ also see strategic value beyond refereeing long-standing scholarly disagreements about the primary objective of choice of law rules; as I explain below, international copyright lawmaking may benefit from decisions rendered employing the substantive law method. ${ }^{247}$ And there are several justifications that apply beyond the context of international copyright law. First, I extend the critique of the formalistic claim that choice of law involves selecting between competing jurisdictions. As David Cavers trenchantly observed, in a conflicts analysis " $[t]$ he court is not idly choosing a law; it is determining a

${ }^{24.3}$ See JOSEPH HeNRY BEALE, A TREATISE ON THE CONFlict OF LAWS OR PRNATE INTERNATIONAL LAW (1916); JOSEPH STORY, COMMENTARIES ON THE CONFLICT OF LAW' (2d ed. 1841).

2:4 See BRAINERD CuRRIE, SELECTEd ESSAYS ON THE CONFLict OF LAWS (1963).

24: In Europe, there was significant resistance to Currie's unilateralist approach. The American "Conflicts Revolution" has not been viewed kindly. See Edoardo Vitta, The Impact in Europe of the American "Conflicts Revolution", 30 AM. J. COMP. L. 1 (1982); see also 2 DICEY \& MORRIS ON THE CONFLICT OF LAWS 1510 (Lawrence Collins et al. eds., 13th ed. 2000) (noting that the approach of the Second Restatement eventually exerted some influence in English law). At the same time, however, European choice of law theory has (like courts applying the First Restatement in the United States) developed its own tools for ensuring apt results, such as increased resort to loi de palice. See, e.g., Cass. le civ., May 28, 1991, 1991 Bull. Civ. I, No. 172, p. 113 (applying French moral rights law to determine whether U.S. copyright owner, taking rights under a contract executed in the United States, could colorize motion pictures first produced in black and white).

:**: See von Mehren, Special Substantive Rules, supra note 229, at 356-57.

${ }^{27^{7}}$ See infra Part III.B.3.c. 
controversy. How can it choose wisely without considering how that choice will affect that controversy?"248 This persuaded Cavers, and ultimately most courts and scholars in the United States, that choice of law must be viewed as a choice between competing rules rather than competing jurisdictions. But I would characterize the judicial role as involving a choice between many competing solutions. Courts in purely domestic cases often (and often should) generate rules, rather than merely apply them, to decide cases and to provide apt solutions. To do so, domestic courts frequently develop the law in a way that does not involve the application of a single pre-articulated rule; they should be free to do so also in multinational cases. Indeed, the legitimacy of an activist approach to judging is enhanced in the multistate context where the competing claims of prescriptive legitimacy are more dispersed among rival institutional claimants, i.e., national legislatures.

What happens when a court is faced with a domestic dispute regarding a set of facts to which no single substantive rule of decision provides an answer? Suppose a set of facts that falls between the two polar extremes of existing rules. The court is not bound to decide the legal effects of the set of facts according to one or other of the existing polar extremes. The court will decide what the appropriate rule should be that governs this new set of facts, drawing most likely upon the extent to which the new set of facts mirrors and implicates the same concerns as the two existing rules. But the court is not obliged to select one or other of the existing models. For example, a court asked for the first time to develop the rules of contract formation when the parties communicated telephonically might draw upon the rules developed for person-to-person communications, on the one hand, and for mail communications on the other. But the rule for telephonic communications need not be the same as either. Why should courts be more constrained when the new variable is the multistate nature of the transaction? If plaintiff would be awarded $\$ 800,000$ under the law of State $X$, and recover nothing under the law of State $Y$, might a cause of action implicating both State $X$ and State $Y$ entitle the plaintiff to recover $\$ 400,000$ (or some other intermediate amount) that reflects the interests of both states?

A second justification, although arguably of less force in the context of recent copyright legislation, is that statutory rules enacted by a

${ }^{248}$ David F. Cavers, A Critique of the Choice-of-Law Problem, 47 HARV. L. REV. 173, 189 (1933). 
national legislature are rarely enacted with an eye to international disputes or conduct. As reflected in the presumption against extraterritoriality, we assume that legislatures generally seek to regulate only domestic conduct and domestic parties. ${ }^{249}$ Putting aside whether legislatures have prescriptive authority to seek exclusively to regulate matters of an international nature, ${ }^{250}$ it is clear that the policies underlying statutes are largely reflective of domestic priorities. These priorities are no less valid for being domestically oriented, but this does not suggest that implementation of legislative direction requires routine application of such policies in an international context.

Indeed, it is quite possible that if a legislature were consciously to address the policies by which it would seek to regulate international disputes before its courts, it might articulate a different policy that took into account the competing interests of other states as well as its own interest. Current methodologies effectively assume that the legis-

${ }^{24 \prime 4}$ See, e.g., Bernkrant v. Fowler, 55 Cal. 2d 588, 594 (1961) (noting that the "[l]egislature ... is ordinarily concerned with enacting laws to govern purely local transactions").

Despite the territorial orientation of international copyright law, our general notions of prescriptive jurisdiction have moved beyond territorial borders. Prescriptive jurisdiction may rest upon the citizenship of parties abroad, and increasingly it is asserted based upon effects (but not conduct) within a national territory. See generally RESTATEIENT (THIRD) OF FOREIGN RELATIONS LAW OF THE UNITED STATES $\$ \S 402-03$ (1987) (providing for the exercise of jurisdiction based on effects within a territory so long as the effect is substantial and the exercise is reasonable, subject to certain limitations); William S. Dodge, Extraterritoriality and Conflict-of-Laws Theory: An Argument for Judicial Unilateralism, 39 HARV. INT'L L.J. 101 (1998) (arguing for a unilateralist approach to international choice of law and thus endorsing an effects test). Arguments for U.S. jurisdiction in copyright cases explicitly based on adverse effects in the United States have largely been unsuccessful. See, e.g., Subafilms, Ltd. v. MGM-Pathe Communications Co., 24 F.3d 1088, 1095 (9th Cir. 1994) (en banc) (declining to exercise extraterritorial jurisdiction over foreign conduct based upon the adverse effects of unauthorized foreign copying on the U.S. film industry, citing long-standing commitment to territoriality in U.S. copyright law and noting the Congressional decision to improve the position of American authors by pushing via treaty negotiation for better protection under foreign copyright laws). But of. Metzke v. May Dep't Stores Co., 878 F. Supp. 756, 761 (W.D. Pa. 1995) (holding that a defendant can be liable where it supplied samples of a copyrighted product to a copier in Taiwan, and it knew or should have known that unauthorized copies made in Taiwan would be distributed in the United States). But willingness to assume jurisdiction based on authorization in the United States, see, e.g., Curb v. MCA Records, Inc. 898 F. Supp. 586, 595-96 (M.D. Tenn. 1995) (rejecting Subafilms and finding mere authorization within the United States of infringing conduct abroad sufficient to state an independent claim under U.S. copyright law), or over foreign acts of contributory infringement that lead to U.S. infringement, see supra note 186 (listing cases finding sufficient basis for jurisdiction on this ground), clearly flows from justifications similar to those that support effects jurisdiction. 
lature would consider only whether it would wish to apply its domestic policy alone to the dispute or defer entirely to the application of the domestic policy of another state. ${ }^{251}$

Third, a method that draws its applicable rule in international cases from an amalgam of national and international norms reflects the complex and interwoven forces that govern citizens' conduct in a global society. Existing choice of law methodology fails to recognize these interacting forces by compelling courts to localize matters that are not local and to judge disputes according to a single norm where citizens do not act (or expect to be judged) according to that norm alone. A substantive law method would seek to reflect rather than to deny that reality of modern life. Congruence between legal methodology and societal development lends legitimacy to the law as an instrument of social organization because it ties the law to the values of the society it purports to organize. The substantive law method rec-

${ }^{251}$ Adaptation of a classic conflicts hypothetical illustrates this point. William Baxter premised his theory of comparative impairment, according to which he suggested courts should resolve choice of law questions, upon the hypothetical negotiation of an interstate compact for the resolution of conflicts. See Baxter, supra note 241, at 7-8 (setting out the hypothetical negotiation). Negotiation of the compact would identify the circumstances in which one state would most insist upon application of its law and when it would be willing, in exchange, to accede to the application of the law of the other state. This theoretical device usefully highlights the factual situations in which a state is relatively more interested, and thus when its interest in the application of its law is strongest. But this hypothetical negotiation could be a much more nuanced process than Baxter presupposes. The bargain struck by the states need not be confined to complete capitulation in one case in return for exclusive prescriptive jurisdiction in another. Negotiating states might compromise along other fault lines. Thus, the solution might be to permit the outcome in a particular case to be determined in part by the law of one state and in part by the law of the other state; that is, the negotiated compact might be to take into account the laws of both states in cases that involve both states. To illustrate this adaptation of Baxter's classic hypothetical, let us reduce the effectuation of the domestic policy objectives of two negotiating states-State $X$ and State $Y$-to numerical values as follows. In each of five cases involving elements from both State $X$ and State $Y$, the domestic law of State $X$ would permit the plaintiff to recover 100 units; recovery of 100 units represents the policy objective of State $X$. Under the domestic law of State $Y$, the plaintiff would in every instance be denied any recovery; this represents the policy objective of State $Y$. Baxter's approach, which reflects traditional choice of law thinking, requires that the two states negotiate over when the plaintiff should recover 100 and when it should recover 0 . Thus, State $X$ may agree that in cases 1-3 it will permit State $Y$ s law to be applied, and the plaintiff be denied recovery. In return, State $Y$ would agree that in cases of type 4 and 5 it will accede to the application of the law of State $X$ and the recovery of 100 units. But the states could bargain differently. The states could agree that in cases of types 1 and 2 the plaintiff will recover 0 , in cases of type 5 the plaintiff will recover 100 units, and in cases of types 3 and 4 the plaintiff will recover 50 units. Indeed, the variations are infinite. 
ognizes that congruence as a necessary part of conflicts law. ${ }^{252}$

Legitimacy of laws is important in practical as well as normative terms. To the extent that copyright law now implicates a far greater number of individuals, often in private spaces, ${ }^{253}$ the question of voluntary public compliance should command greater attention in devising appropriate rules of copyright law. Compliance, in turn, rests in large part upon perceptions of legitimacy. ${ }^{254}$ Maximizing the relation between the normative impulses of citizens and the legal rules that are

${ }^{272}$ The argument that the United States should limit application of its purely domestic copyright law to international behavior causing effects within the United States is not fundamentally based upon the normative weakness of U.S. claims to prescribe, nor upon the descriptive (in)ability of the United States to regulate local effects of extraterritorial conduct (which is really a function of both adjudicative jurisdiction and the presence of assets in the United States). Rather, the proposal advanced in this Article rests primarily upon the equal legitimacy of the claims of other nations and communities to regulate the same behavior. That is, it rests upon an excess (rather than a lack) of normative prescriptive authority. In such a circumstance, comity concerns should counsel in favor of more cautious assertions of prescriptive jurisdiction. To the extent that a normative attack can be launched upon the application of U.S. law to such international settings, it can hinge only upon the inappropriateness of exclusive U.S. prescriptive jurisdiction. But where choice of law methodologies compel courts to select a single governing law, the decision to apply U.S. law exclusively rather than a different national law exclusively hardly can be criticized where that different national law also has a normative claim only to some, but not exclusive, application. Current choice of law methods fail to recognize these normative limits (i.e., the notion that the limits of prescriptive jurisdiction should be set by a claim to have some but not exclusive application to a set of facts). The substantive law method, by giving prescriptive effect to both laws, permits this normative limitation to be recognized. Jack Goldsmith disputes this normative refinement, arguing that "one jurisdiction's legitimate regulation of the harmful local effects of extraterritorial activity does not become normatively problematic simply because the harm-producing activity also produces harmful effects in many other jurisdictions and thus is subject to territorial regulation there as well." Goldsmith, supra note 25, at 484. But cf. id. at 487 ("Most normative perspectives frown on a nation that exports the costs of its regulation to other nations whose citizens have no voice in the enactment or enforcement of the regulation."). I would contend that where the other national regulation affirmatively permits what the forum prohibits, normative concerns do arise, although it might be better to phrase this as a question of relative rather than absolute normative appropriateness. Of course, the application of a single law to a transnational setting has always raised these concerns, and the normative validity of applying a single law has traditionally been unquestioned (the debate largely centering on which law should be applied). But the range of circumstances in which competing prescriptive claims arise has increased, and the substantive law method may offer a better normative mapping, if not the only valid one, in such cases than the application of a single law.

${ }^{253}$ See supra text accompanying notes 51-53 (describing how copyright law often intrudes on the personal lives of citizens).

234 See Tom R. Tyler, Compliance with Intellectual Property Laws: A Psychological Perspectix', 29 N.Y.U.J. INT'L L. \& POL. 219, 224 (1997) (arguing that, absent effective deterrent measures, compliance with the law must be grounded in morality and legitimacy). 
declared to govern citizens' lives furthers legitimacy and thus the level of public compliance required for effective copyright laws. ${ }^{255}$ We should therefore pursue a choice of law methodology, like any other type of law formation, that permits the closest possible coincidence between the applicable rule and the norms that motivate human behavior.

Fourth, the fact that a dispute is multinational means that it implicates interests that are different from those implicated in equivalent domestic cases. If the dispute implicates substantial interests of both State $A$ and State $B$, it is inequitable to treat such facts (automatically) in the same way as either a dispute wholly implicating the interests of State $A$ or wholly implicating the interests of State $B^{256}$

\section{ii. Sources of Law}

An essential threshold question under the substantive law method is what sources of law, or considerations, will guide a court engaging in this more activist endeavor. Courts are unable to generate norms from within; once untethered from the analysis of choosing between two existing norms, they need guidance. Without seeking to constrain courts unduly, I consider here four basic considerations: international agreements and practices; national and regional laws; developing post-national groupings; and conflicts values.

The constraints upon the sources of law to which judges might refer in this process will, to some extent, flow naturally from consideration of how to sell legitimacy in a system in which reason is the ultimate force. Thus, one would expect any outcome to fit within the boundaries established by the laws of the respective states with interests, ${ }^{257}$ and also that it would comply with any clear provisions of public international copyright law. ${ }^{258}$

${ }^{255}$ See Jessica Litman, Copyright Noncompliance (or Why We Can't "Just Say Yes" to Licensing), 29 N.Y.U. J. INT'L L. \& POL. 237, 240-41 (1997) (arguing that copyright laws that "make sense" are the only laws that will be effective).

${ }^{256}$ See von Mehren, Special Substantive Rules, supra note 229, at 356 (recognizing that "serious problems" arise in treating cases with multistate elements as if they were solely domestic).

${ }^{237}$ See infra note 264 (distinguishing my proposal from those advanced by advocates of a separate cyberlaw governing cyberspace transactions).

${ }_{258}$ Dreyfuss and Lowenfeld construct similar restraints on WTO panels faced with analyzing the legitimacy of antitrust remedies that limit the exercise of intellectual property rights. See Dreyfuss \& Lowenfeld, supra note 99, at 313 (suggesting that any antitrust enforcement action that fell on the spectrum between the U.S. and EU positions on the relationship between competition and intellectual property should be up- 
International copyright agreements, such as the Berne Convention, the TRIPS Agreement, and the WIPO Copyright Treaty would represent an obvious starting point for the ascertainment of international norms. ${ }^{259}$ These different agreements, however, are not uniform in tone. While TRIPS is premised solely upon the notion that inadequate protection of intellectual property constitutes a barrier to international trade, the Berne Convention is based upon the goal of ensuring uniformly high protection for the works of authors, tempered by concerns about a scope of protection that accommodates uses by others in the public interest. This tempering is made explicit in the language of the WIPO Copyright Treaty, but has always been part of the historical Berne debate. There is, therefore, ample room for debate regarding the different import of these treaties, notwithstanding their obvious relevance.

But examination of the substantive principles found in these treaties would be a relatively new endeavor for U.S. courts. It is rare for U.S. courts to make reference to the standards announced in international intellectual property treaties because most have not been treated as self-executing. ${ }^{260}$ Moreover, as Paul Geller has suggested, the interpretation of the text of the Berne Convention (now incorporated in TRIPS) might vary from a public international to a private international setting:

[T] he Paris and Berne Conventions ... constitute a regime of private international law to ensure respect for property interests in these products

held by a WTO panel, if consistent with each of those laws, unless expressly prohibited by the TRIPS Agreement). This interaction is not addressed by the TRIPS Agreement, and it is therefore not surprising that one would resort to considerations that flow from the common law adjudication process and the need to persuade.

223 Some scholars suggesting an approach to copyright choice of law other than the substantive law method have entertained the prospect of referring to international standards. Most notably, Professor Jane Ginsburg has described an approach that would make some use of public international measures in applying conflicts principles to multinational copyright infringement claims. She argues that:

Another approach ... would nominally apply the rule of territoriality, but, at least where all relevant countries are Berne Union or WTO members, would presume that all affected territories adhere to Berne-TRIPS minima. Since the forum under these circumstances would also be a Berne-WTO country, the court might further presume that all the relevant countries' laws are like the forum's. The court would then apply its own law to the full extent of the claim, subject to a showing that in certain countries, local norms are either more or less protective than the forum's.

Ginsburg, supra note 3, at 284 (citation omitted).

${ }^{2 * * 1}$ But see Gen. Motors Corp. v. Lopez, 948 F. Supp. 684, 690 n.5 (E.D. Mich. 1996) ("The Lanham Act incorporates the substantive provisions of the Paris Convention and thus creates a federal law of unfair competition applicable in international disputes."). 
across national borders. On the other hand, the [WTO], in administering the TRIPS Agreement,... will maintain a truce in an all-tooconcrete, Hobbesian war of each against all. . . Paris, Berne, and related treaty provisions need not always mean the same thing in the abstract Cartesian universe of intellectual property as in the concrete Hobbesian world of trade wars and truces. ... Domestic courts could construe ParisBerne obligations differently than do TRIPS panels, resulting in jurisprudential schizophrenia between the private and public international laws of intellectual property. ${ }^{261}$

This makes sense; the treaties are being used for different purposes in these two settings. In the private law context, they are being used by courts prospectively to guide the ascertainment of an apt solution and the optimal development of the law; in the public law context, they are being used merely to indicate what states had agreed to undertake as minimal levels of protection. ${ }^{262}$ National courts will make reference to the conventions against a backdrop of national legislation and canons of interpretation, and in light of other tangential considerations that will color their analysis. The backdrop against which WTO panels consider the same language is quite different.

National norms of interested states (and perhaps of states without interests in the particular dispute) ${ }^{263}$ would also clearly be relevant in

${ }^{261}$ Geller, supra note 136, at 103-04.

${ }^{262}$ Similarly, customary international law would be relevant, as it is potentially in cases before the WTO. See supra note 138 (discussing the DSU). Customary international law is, however, no less backward looking than treaty provisions. While there is no precise definition of customary international law, the claim of a rule to such a status is enhanced by widespread conforming state practice over a long period of time. See RESTATEMENT (THIRD) OF THE FOREIGN RELATIONS LAW OF THE UNITED STATES $\$ 102$ $\mathrm{cmt}$ b (1987) (discussing the role of state practice in establishing the content of international law).

${ }^{263}$ Comparative analysis might inform the search for apt solutions even where the comparative model in question is provided by a country with no direct interest in the litigation. Indeed, some members of the U.S. Supreme Court appear willing to consider as "relevant and informative" decisions of foreign courts even when interpreting the U.S. Constitution. See, e.g., Knight v. Florida, 120 S. Ct. 459, $463-64$ (1999) (Breyer, J., dissenting from denial of certiorari) (considering the death penalty jurisprudence of India and Zimbabwe in evaluating the claim that the Eighth Amendment prohibits as cruel and unusual punishment the execution of prisoners who have spent nearly twenty years on death row); Printz v. United States, 521 U.S. 898, 976 (1997) (Breyer, J., dissenting) (having regard to how other countries with federal systems have reconciled tensions between the practical need for central authority and the democratic virtue of local control in determining whether federal gun regulation unconstitutionally required state officers to execute federal laws); see also Mark Tushnet, The Possibilities of Comparative Constitutional Law, 108 YALE L.J. 1225 (1999) (suggesting a systematic approach to learning from other countries' constitutional theory and practice); Mark Tushnet, Returning With Interest: Observations on Some Putative Benefits of Studying Comparative Comstitutional Law, I U. PA. J. CONST. L. 325 (1998) (describing issues associ- 
developing rules applicable to international disputes. ${ }^{264}$ But whereas, when traditional choice of law selects a national law to apply, it applies only that one national norm, the substantive law method will seek to examine all relevant national norms in developing an international rule that may match no single national norm. ${ }^{265}$

Courts in international cases might also consider norms developing in postnational settings, such as might exist on the internet. ${ }^{266}$ Domestic U.S. courts have taken account of the social realities of communities that transcend formal political borders. ${ }^{267}$ Recognizing

ated with "borrowing" and "lending" constitutional ideas); $(f$. Sandra Day O'Connor, Federalism of Free Nations, in INTERNATIONAL LAW DECISIONS IN NATIONAL COURTS 13, 18 (Thomas M. Franck \& Gregory H. Fox eds., 1996) (suggesting that as "our domestic courts are increasingly asked to resolve disputes that involve questions of foreign and international law... there is great potential for our Court to learn from the experience and logic of foreign courts and international tribunals"). In the context of particular litigation, pragmatism might, however, suggest some limit on the scope of countries whose interests (as embodied in their laws) should be factored into the equation. Comparative examination of uninterested countries, albeit with claims to provide helpful solutions, might thus weigh less heavily on the scales.

${ }^{214}$ This distinguishes my proposal from those advanced by scholars described by Jack Goldsmith as "regulation skeptics." The application of norms found in cyberspace is no less arbitrary than the application of the law of a single terrestrial place; spillover effects occur from online to the terrestrial world just as the internet causes them to occur from one country to another. See supra note 224.

$27^{5}$ It is also possible that certain international cases might still warrant application of a rule that closely approximates a single national rule. That is, the facts of some international disputes may so strongly implicate the norms of a single state that the scales would weigh more heavily in the direction of that national rule. Indeed, one would expect the courts to develop case law on when national norms would be afforded more weight than international norms.

2iki The ways in which norms may be imposed in cyberspace might not always be obvious to the legal eye. See, e.g., LAWRENCE LESSIG, CODE AND OTHER LAWS OF CIBERSPACE (1999) (discussing the ability of computer code to regulate conduct in cyberspace); Boyle, supra note 182, at 204-05 (suggesting that the state may effectively and less obviously regulate cyberspace through means that are concealed if one views law only in Austinian terms of a command backed by threats). In the context of the internet, standards might be extracted both from the behavioral norms of actors on the web and from written principles and guidelines found in service provider contracts, "acceptable use and conduct" policies, and online "netiquette" guides. Moreover, as noted above, see supra text accompanying note 183, online dispute resolution services consciously use cyberstandards to decide disputes, and such decisions may (while not amounting to an official reporting system) usefully gather written statements of norms in one place for more centralized reference.

${ }^{267}$ See, e.g., Kaiser-Georgetown Cmty. Health Plan, Inc. v. Stutsman, 491 A.2d 502 , 509 \& n.9 (D.C. 1985) (taking into account the "present reality of the economically and socially integrated greater metropolitan area" around the District of Columbia in finding a D.C. interest in protecting the rights of a Virginia citizen working in D.C. (quoting Gaither v. Myers, 404 F.2d 216, 223 (D.C. Cir. 1968))). 
such realities may better effectuate justified expectations of parties ${ }^{268}$ operating in such a community, ${ }^{269}$ and may also avoid fortuitousness in ways that rigid adherence to formal political institutions does not. Moreover, the analytical processes of adjudication, no less than explicit lawmaking, police and filter the forms of knowledge and understanding that receive validation through law. Thus, when we talk of producing or developing the norms of the cybercommunity, it may be more accurate to say that the analytical methods of choice of law adjudication will assist in bringing those to a head, in rationalizing disparate and divergent views of what those norms are, and in validating some but not others. This is in many respects an important role of law as a formal institution. ${ }^{270}$

${ }^{268}$ Goldsmith concludes (accurately) that developments in twentieth century conflicts scholarship and case law mean that "ex ante notice of a specific governing law is no longer a realistic goal in many transnational situations." Goldsmith, supra note 27, at 1208. But this descriptive accuracy should not preclude normative assessment of the continuing value of notice and justified expectations. Recent jurisprudential developments might have minimized the importance of these values, and recent social developments may have made their effectuation more difficult, but that should not detract from their normative claim to relevance. Notice of governing laws, and a related representational concern of a voice in the articulation and revision of such laws, remain values with important democratic resonance. It may no longer be (indeed, it may never have been) a feasible lodestar for choice of law analysis, but it still makes a strong claim to consideration.

${ }_{269}$ Respecting the expectations of persons operating in international or cyberspace transactions does not mean that regard should be had only to international or cyberspace norms. International disputes implicate both national and international interests, and thus a national law addressing such disputes might appropriately have regard to national as well as international considerations. Cyberspace disputes implicate both cyberspace and offline norms, and thus adjudication of cyberspace conduct must consider both cyberspace and offline norms. This is why I disassociate myself from those scholars who seek to have cyberspace regulated solely by cybernorms. See supra notes $224,264$.

${ }^{270}$ One concern that reference to such norms might cause is how courts are to ascertain such norms: which postnational groupings are to be given consideration? This problem is less significant when reference is made only to conventional, formal sources. The validity of such sources is determined by what H.L.A. Hart called "secondary rules," more particularly, "rules of recognition." H.L.A. HART, THE CONCEPT OF LAW 92-93, 97-107 (1961) (defining "secondary rules" as those rules that ascertain, introduce, eliminate, or vary primary rules of obligation). But no such secondary rules exist with respect to norms developed without reference to a traditional sovereign. Although one could argue that the nondispositive nature of the norm of any single grouping mitigates this concern, the legitimacy and the efficiency of my proposal requires that courts develop secondary rules for determining the relevance of such additional norms. Cf. Robert Cooter, Decentralized Law for a Complex Economy: The Structural Approach to Adjudicating the New Law Merchant, 144 U. PA. L. REV. 1643 (1996) (discussing the conditions under which norms can fairly and efficiently evolve and how the new law merchant can incorporate those norms). Moreover, absent such secondary rules, there is a danger that certain communities would be accorded too much power 
Finally, so-called "conflicts principles" should be considered. The Restatement of Foreign Relations contains a ready-made list that is not dramatically different from considerations applied in domestic cases. ${ }^{271}$ For example, it will be important to develop rules that do not further a race to the bottom by overemphasizing the rules of a place in which pirates can establish operations with impunity. In the maritime context, in Lauritzen v. Larsen, ${ }^{272}$ the U.S. Supreme Court emphasized that, in determining the law applicable to an on-board accident, it would accord little weight to the place where the contract between seaman and vessel owner was made because that would be "not unlikely in the long run to diminish hirings in ports of countries that take best care of their seamen. ${ }^{273}$ Similarly, choice of law analysis should take into account the goal of ensuring uniformity of treatment. In Lauritzen, the Supreme Court noted that "[t]he purpose of a conflict-of-laws doctrine is to assure that a case will be treated in the same way under the appropriate law regardless of the fortuitous circumstances which often determine the forum." ${ }^{274}$ This latter objective has been a consideration in most, but not all, choice of law models. ${ }^{275}$

in developing contemporary copyright law and that such power would go largely unnoticed. Cf. Super Tuesday, HousTON CHRON., Mar. 8, 2000, at 17 (noting challenge by the Voter Integrity Project to online voting in the Arizona democratic presidential primary election). See generally Neil Weinstock Netanel, Cyberspace Self-Governance: A Skeptical View From Liberal Demacratic Theory, 88 CAL. L. REV. 395 (2000) (critiquing claim that a self-governing cyberspace would more fully realize liberal democratic ideals).

271 See RESTATEMENT (THIRD) OF FOREIGN RELATIONS LAW OF THE UNITED STATES $\$ 403$ (2) (1987) (providing that the determination whether the exercise of prescriptive jurisdiction is unreasonable should be based on factors that include: the "link of activity to the territory of the regulating state," the character of the activity to be regulated, the connections between the regulating state and the person principally responsible for the activity to be regulated, the existence of justified expectations, and the extent of competing state interests); see also Hartford Fire Ins. Co. v. California, 509 U.S. 764, 818 (1993) (Scalia, J., dissenting) (discussing the factors necessary to determine "reasonableness" in the exercise of prescriptive jurisdiction).

272 345 U.S. 571 (1953).

${ }^{273} I d$, at 588 .

274. at 591 .

${ }^{275}$ See RESTATEMENT (SECOND) OF CONFICTS OF LAwS $\$ 6$ (1971) (identifying the principles by which to determine applicable law, and including "certainty, predictability and uniformity of result"). This was not a concern of Brainerd Currie, the father of governmental interest analysis. See CURRIE, supra note 244, at 169 (advocating a "harder and closer look at the ideal of uniformity"). Achievement of this objective may also be heavily dependent upon different jurisdictions applying the same choice of law rule, providing a further reason for implementing the approach advanced in this Article by means of an international convention. See infra note 342 (discussing the means of implementing this proposal). 
iii. Application of the Substantive Law Method

How would this approach to copyright choice of law work in practice? At first blush, one might think that the answer is unclear because it is difficult to predict how judges in a range of countries will develop an approach avowedly different in concept from that presently employed to resolve international conflicts of laws in most of those countries. Yet, although the precise conflicts methodology would be new, ${ }^{276}$ the thought process for which it calls consciously mimics in different ways what modern judges do both in purely domestic cases and in multistate cases within the United States. ${ }^{27}$ To illustrate, and to develop further some aspects of the substantive law method discussed above, let us consider some variants on a hypothetical private international litigation.

Sam Appletart is an American artist and the owner of the copyright in a series of four paintings entitled "Liberty." Appletart has licensed the U.S. publication of the Liberty series in various formats, including in coffee-table books of modern American art and in textbooks on American art. She discovers that a reproduction of the Liberty series has been posted, without her permission, on a web site hosted by a university in the (fictitious) European country of Caledonia (which, like the United States, is a signatory to the Berne Convention, TRIPS, and the WIPO Copyright Treaty). The paintings had been scanned into digital format by the university. The paintings are posted on a web page established for a university course on contemporary North American art. The university imposes no restrictions on access to the web page; it adheres to the view that education is the right of all citizens and that free access to course materials is consistent with this philosophy. It also does not wish to use precious university resources on technological devices to restrict access to class members; it has discovered from experience that students are remarkably adept at circumventing such measures and that the cost of ensuring effective protection is prohibitive.

The Caledonian university has a sister-university relationship with New York University, which involves student and faculty exchanges

${ }^{276}$ But see supra text accompanying notes 229-32 (discussing historical antecedents).

${ }^{277}$ Claiming that what I require involves nothing more than the usual processes of judicial interpretation is, of course, a standard ploy among conflict scholars. This probably speaks more to the eclecticism of modern methods of judging rather than any disingenuousness on the part of conflicts scholars. 
and the administration of a summer program in New York City. ${ }^{278}$ The web site is accessible from the United States. Let us assume that the unauthorized posting of the paintings would constitute infringement under U.S. law (if applicable). Although the use in question falls outside the specific exemptions contained in the Copyright Act for educational uses, ${ }^{279}$ educational uses are favored under the doctrine of fair use. $^{2{ }^{2} \cdot 1}$ The nonprofit nature of the university would also bolster a claim of fair use. ${ }^{281}$ But these considerations are not dispositive. ${ }^{282}$ The posting of the paintings without further second-comer creative activity is probably not transformative, ${ }^{283}$ a consideration fast becoming the central question in fair use analysis. ${ }^{284}$ And, although the uni-

${ }^{27 x}$ This most likely makes the university subject to personal jurisdiction in New
York.
See 17 U.S.C. $\$ 110(1)$ (1994) (exempting performances of copyrighted works given by instructors or pupils in the course of face-to-face teaching activities of a nonprofit education institution, provided that the performance takes place in a classroom or other place devoted to teaching); id. $\$ 110(2)$ (exempting certain transmissions of nondramatic literary works in instructional settings, conditional upon the existence of a limited reception network).

'sk' See id. $\$ 107$ (including teaching as an illustrative use that might, after due consideration of statutory factors, be a fair use).

${ }^{2 * 1}$ See id. $\$ 107$ (1) (instructing courts to consider whether a use is for nonprofit educational, as opposed to commercial, purposes in determining a claim of fair use); H.R. REP. No. 94-1476, at 66-67 (1976) (suggesting that nonprofit educational use is a good indication of fair use).

${ }_{2 \times 2}$ See, e.g., Encyclopaedia Britannica Educ. Corp. v. Crooks, 542 F. Supp. 1156 (W.D.N.Y. 1982) (holding that a large-scale reproduction by an educational service of copyrighted works originally broadcast on television did not constitute fair use). In Crooks, the primary market for the plaintiff's products was educational in nature, and a licensing arrangement was available. Here, the posting of the paintings on the web probably does not impinge upon several important primary markets for the work, where the originals or hard-copy prints of high quality are essential.

${ }^{2 * 3}$ A mere change in medium will not ordinarily be considered transformative. See Am. Geophysical Union v. Texaco Inc., 60 F.3d 913, 923 (2d Cir. 1994) (holding that mere photocopying onto a new physical copy cannot properly be regarded as a transformative use of copyrighted material); see also Infinity Broad. Corp. v. Kirkwood, 150 F.3d 104, 108 (2d Cir. 1998) (holding that the unaltered retransmission of a radio broadcast by a different means designed to permit customers to listen in areas outside the broadcast organization's reception area was not a transformative use); $c f$. Religious Tech. Ctr. v. F.A.C.T.Net, Inc., 901 F. Supp. 1519, 1525-26 (D. Colo. 1995) (finding unmodified posting intended to foster dialogue to be fair use). See generally Pierre N. Leval, Toward a Fair Use Standard, 103 HARV. L. REv. 1105 (1990) (discussing the relevance of transformativeness in the fair use inquiry).

${ }^{2 * 4}$ See Laura Lape, Transforming Fair Use: The Productive Use Factor in Fair Use Doctrine, 58 ALB. L. REV. 677 (1995) (questioning the value of focusing on transformativeness); Diane L. Zimmerman, The More Things Change the Less They Seem "Transformed": Some Reflections on Fair Use, 46 J. Copyright SOC'Y U.S.A. 251 (1999) (same). But cf. Sony Corp. of Am. v. Universal City Studios, Inc., 464 U.S. 417 (1984) (finding fair use 
versity may need to post the paintings in their entirety to fulfill its objectives of art appreciation, ${ }^{285}$ several courts have placed significant weight, even after the Supreme Court's decision in Campbell v. AcuffRose Music, ${ }^{286}$ on whether a market mechanism for licensing the use of the work is in place. ${ }^{287}$ The fact that Appletart has licensed the use of the paintings in textbooks suggests that some market for the work exists. ${ }^{288}$ In short, Appletart would have an arguable case that this is not fair use. Indeed, even if the university's activities would have been privileged in the hard-copy world (i.e., if the class members had been given a hard copy reproduction of the paintings), ${ }^{289}$ it is not clear how these privileges apply in the digital world. ${ }^{290}$

Let us also assume that Caledonian law offers broad exceptions to educational institutions to reproduce copyrighted material for instructional purposes. In an effort to encourage distance-learning-Caledonia is a large country with students in far-flung locales-it has extended its broad exemptions into the digital environment. Thus, if U.S. law applies to the university's activities, the web site would be held to be infringing. An injunction would ordinarily issue to restrain

where use was not transformative).

285 See Campbell v. Acuff-Rose Music, Inc., 510 U.S. 569, 586-89 (1994) (noting that the amount of permissible fair use copying varies with the amount needed by users to serve their fair use purpose).

${ }^{286} \mathrm{Id}$.

${ }^{287}$ See Princeton Univ. Press v. Mich. Document Servs., Inc., 99 F.3d 1381, 1385 (6th Cir. 1996) (en banc) (evaluating the extent of harm to the plaintiff's market caused by unlicensed copying and noting that licenses could have been obtained through existing mechanisms, namely departments maintained by plaintiffs and the Copyright Clearance Center); Am. Geophysical Union, 60 F.3d at $929-30$ (placing weight on the existence of a licensing mechanism operated by the Copyright Clearance Center).

288 It would not matter, however, whether Appletart was already exploiting a particular market; the focus is on potential markets. See Campbelh, 510 U.S. at 591-93 (emphasizing that the owner of copyright in a rock and roll ballad is entitled to receive the value of exploitation in both primary and derivative markets, such as the market for rap versions of the song, and is entitled to protect such derivative markets even if he has not yet entered them).

${ }^{289}$ Cf. Agreement on Guidelines for Classroom Copying in Not for Profit Educational Institutions with Respect to Books and Periodicals, H.R. REP. No. 94-1476, at 6871 (1976) (establishing guidelines for classroom copying of books and periodicals).

${ }^{290}$ See Spoor, supra note 69 , at 40 (noting that the potential impact of digitization is such that existing user privileges in the off-line world might not simply translate into parallel digital privileges); D.J.G. Visser, The Netherlands National Report, in CoPYRIGHT IN CYBERSPACE 124, 130 (Marcelle Dellebeke ed., 1997) (suggesting that it was unclear whether educational copying exceptions under Dutch law applied in the digital environment such that "making a work available in a very small network that would only reach (the equivalent of) one classroom might be covered by the existing educational use exception"). 
infringement. If Caledonian law applies, the university would get off scot-free. Which law should apply?

Under a traditional analysis, one would consider the place where the alleged infringement occurred. Although the initial act of reproduction occurred in Caledonia, could a U.S. court find U.S. conduct sufficient to justify the application of U.S. law? The short answer is that a U.S. court could almost certainly (by virtue of access to the web site in the United States) construe the Caledonian web site as implicating the publication of the work (i.e., the distribution of copies to the public) in the United States. ${ }^{291}$ Under this reading, and adopting a traditional approach to choice of law, U.S. law would almost certainly be applied by the U.S. court. ${ }^{292}$

How would this dispute be resolved under the method proposed in this Article? A federal court in the United States would develop a substantive rule to decide this type of international case, considering all relevant interests-national, international, and postnational. ${ }^{293}$

See Playboy Enters., Inc. v. Chuckleberry Publ'g, Inc., 939 F. Supp. 1032, 1040 (S.D.N.Y. 1996) (ordering an Italian web site to prohibit U.S. users from gaining access to the allegedly infringing site); see also Allarcom Pay Television, Ltd. v. Gen. Instrument Corp., 69 F.3d 381, 387 (9th Cir. 1995) (deciding that performance occurs at place of receipt of satellite transmission); National Football League v. TVRadioNow Corp., 53 U.S.P.Q.2d 183I, 1834-35 (W.D. Pa. 2000) (holding that where defendants originated the streaming of copyrighted programming over the internet from a web site in Canada, public performances occurred in the United States because users in the United States could access the web site and receive and view the defendants' streaming of the copyrighted material). For a full analysis of this argument, see Ginsburg, Cyberian Captivity, supra note 218 , at 354-57.

${ }^{2 \times 2}$ See TVRadioNow Corp., 53 U.S.P.Q.2d at 1837-38 (declining to address whether streaming of copyrighted programming was permissible under Canadian law because plaintiffs sought relief against public performances in the United States that occurred when users in the United States accessed the web site in Canada and received and viewed the streamed programming); Ginsburg, Cyberian Captivity, supra note 218, at 356-57; cf. Austin, supra note 189, at 4 (suggesting an approach that would apply U.S. law only to copyright infringements-that is, publication-occurring within the United States).

It should also be recognized that the substantive law method may in appropriate circumstances result in the application of purely national norms, if the courts determine that the case is essentially more national than international. See supra note 265. For example, if a print for a motion picture is made in the United States and publicly performed in movie theaters in six different countries, and if the authority of the defendant to do so is challenged, then the existence of separately bargained-for rights under different national markets might warrant an insistence upon serial application of separate national laws. See Boosey \& Hawkes Music Publishers, Ltd. v. Walt Disney Co., 145 F.3d 481, 491-92 (2d Cir. 1998) (reversing order dismissing claims under several separate foreign copyright laws on forum non conveniens grounds). In such circumstances, permitting the plaintiff to sue in the United States based upon separate foreign copyright laws might best give respect to the foreign laws. But if the predicate 
The court would first look at the national laws implicated by the dispute, namely those of Caledonia and the United States. ${ }^{294}$ Consistent with modern American approaches to choice of law, the court would consider not only the bare rule, but also the purposes that undergird it. Scholars and courts have explained in great detail the need to understand the purposes underlying a rule in order to identify (and respect) the interests of the states involved in having their laws applied. And, although analysis of the purposes behind foreign laws has its pitfalls, ${ }^{295}$ access to foreign materials is continually improving. ${ }^{296}$ Indeed, it may be that a full understanding of the purposes underlying a law are even more essential to an appreciation of the meaning and import of a foreign law than is the case with the law of a different U.S. state. Bare words may be more readily susceptible to different (and incorrect) meanings when cultural and linguistic divides are crossed.

This consideration of national laws distinguishes my approach from that advocated by cyberlaw proponents (who Jack Goldsmith has called "regulation skeptics" ${ }^{\text {2977 }}$ ), namely the application of cybernorms without regard to the physical space in which the cyberactors are situated. Just as application of U.S. law (under the traditional approach)

U.S. activity becomes more central to the transaction, the claim to apply certain aspects of U.S. law (for example, remedies granting attorneys' fees) might become stronger.

Yet this example should not be taken to suggest that only cyberspace transactions can be subject to the full rigors of the substantive law method. The theoretical justifications adumbrated above apply with as much normative force to any international transaction, although the pragmatic, practical appeal of the methodology may have more resonance in the cyberspace context. For example, if a global event such as the Olympics is being televised around the world and a copyright dispute arises with respect to the worldwide transmission of the motion picture, the law of the site of the Olympics would indeed have a strong claim to regulate that dispute, but that claim may need to be tempered by the recognition that the global effects may be more substantial than the local conduct.

${ }^{294}$ One could, of course, argue that the laws of any number of countries are implicated if one adopts the reading of "publication" tendered in the text. This may seem more daunting than it is likely to be in practice, because there will only be so many variations in rules among the interested countries.

295 See Donald T. Trautman, A Comment, 67 ColuM. L. REv. 465, 469 (1967) (suggesting different understandings of the purpose of the Ontario guest statute at issue in Babcock v. Jackson, 191 N.E.2d 279 (N.Y. 1963)); see also Neumeier v. Kuehner, 286 N.E.2d 454, 455 (N.Y. 1972) (noting that the seminal decision in Babcock may have been based on an erroneous understanding of the purpose of the Ontario law in question).

See P. John Kozyris, Comparative Law for the Twenty-First Century: New Horizons and New Technologies, 69 TUL. L. REV. 165, 175 (1994) (discussing the effect of enhanced access to information on whether civil law or common law forms of reasoning will likely prevail internationally).

${ }^{297}$ Goldsmith, supra note 27 , at 1199. 
would ignore the spillover effect that U.S. rules would have on the Caledonian education system, so too exclusive reliance on cybernorms ignores the spillover effect that digital rules have on terrestrial actors and events. The substantive law method will consider each of these affected interests.

What would examination of the purposes of the different rules reveal? It would reveal first that Caledonia does offer copyright protection to works of art; it is not a copyright haven. If it were, we might adopt a less generous attitude to the exceptions. Moreover, an examination of the Berne Convention reveals a solicitude for educational uses of copyrighted works. Article 10(2) provides that countries may permit the use, "to the extent justified by the purpose, of literary or artistic works by way of illustration in publications, broadcasts or sound or visual recordings for teaching, provided such utilization is compatible with fair practice." ${ }^{298}$ This suggests that the Caledonian policy is entitled to some weight.

The U.S. position is also entitled to some weight, however. The TRIPS Agreement is premised upon the ability of copyright owners to exploit the value of copyrighted works in foreign markets; indeed, the Caledonian activity may impede the ability of Appletart to exploit existing markets both domestically and abroad. Moreover, a market for the product exists, suggesting that the Caledonian use will interfere with the normal exploitation of the work. ${ }^{299}$ (Indeed, the free access

${ }^{24 \times}$ Berne Convention, supra note 15, art. 10(2), 1161 U.N.T.S. at 38; see also WIPO Copyright Treaty, supra note 36 , pmbl. cl. 5 ("Recognizing the need to maintain a balance between the rights of authors and the larger public interest, particularly education, research and access to information." (emphasis added)).

See TRIPS Agreement art. 13 (requiring signatory states to confine any limitations to "certain special cases which do not conflict with a normal exploitation of the work and do not unreasonably prejudice the legitimate interests of the rightholder"); WTPO Copyright Treaty, supra note 36, art. 10 (adopting the same test). There is a danger of reading a Texaco-like interpretation of "normal markets" into Article 13. See Am. Geophysical Union v. Texaco, Inc., 60 F.3d 913, 929-31 (2d Cir. 1994) (analyzing markets relevant to the question of harm and giving weight to the existence of licensing mechanisms in an existing market). If this occurs, national laws could never seek to recalibrate the balance in copyright law by creating a new exception or limitation for a circumstance in which the copyright owner could previously have extracted a license fee. Construed in this fashion, Article 13 could embody a one-way ratchet unsuited to the dynamic and uncertain state of the means by which works will be exploited in the digital environment. Cf. Agreed Statement Concerning Article 10 of the IVIPO Copyright Treaty, WIPO Doc. CRNR/DC/96 (Dec. 23, 1996), available at http://www.wipo.int/eng/diplconf/distrib/96dc.htm ("Contracting Parties [may] carry forward and appropriately extend into the digital environment limitations and exceptions in their national laws which have been considered acceptable under the Berne Convention. Similarly, these provisions should be understood to permit Con- 
means that Appletart's noneducational markets may also be affected in addition to the educational market.)

Certain considerations suggest that the court should strive for a middle ground. First, U.S. policy on distance learning has not yet developed; ${ }^{300}$ U.S. law has not yet adopted a firm position on the scope of educational exceptions in the digital environment. Second, the concept of fair practices embodied in the Berne Convention encourages the reference to external norms. Practices both in the educational community and the internet community appear to be appropriate referents. Both probably favor some latitude to the university. Finally, comity suggests that U.S. courts recognize the different educational challenges with which the Caledonian university is faced by virtue of the geography of that country.

So what solutions should the court consider? At either extreme, the court could apply U.S. law (and grant an injunction) ${ }^{301}$ or apply Caledonian law (and deny relief). Under traditional choice of law analysis this would be the limit of a court's choice. But the substantive law method suggests that the court develop a solution that accommodates more than one interest. ${ }^{302}$ The two most obvious practical solutions are requiring the university to impose technological measures

tracting Parties to devise new exceptions and limitations that are appropriate in the digital network environment."). The public international law standards can be viewed as a baseline for the development of international principles through the substantive law method. But, as discussed above, see supra Part II.C.2, the international law standards should not be interpreted in an activist manner, and thus I view them as imposing only general limits on national autonomy, with further refinement of the appropriate standards to be pursued by the process discussed in this part of the Articlenamely the use of the substantive law method in international copyright litigation. See supra note 155.

${ }^{300}$ For a thorough discussion of the issues raised by distance learning, see U.S. COPYRIGHT OFFICE, REPORT ON COPYRIGHT AND DIGITAL DISTANCE EDUCATION (1999).

${ }^{801}$ As a practical matter, the enforcement of the injunction would likely be pursued through contempt proceedings. Foreign courts are more likely to enforce judgments awarding financial penalties than orders purporting to regulate conduct on their soil.

${ }^{302}$ Cf. Proposed Information Society Directive Common Position, supra note 147, art. 5(3) (a) (permitting exceptions from scope of reproduction right where the use is for the sole purpose of teaching and there is acknowledgment of source and provision for fair compensation). Publishers have argued that a compensation condition is essential because the "cost of ... educational ... policies ought to be assumed by society as a whole and not only by rightholders." Charles Clark, Net Law: A Cyberspace Agenda for Publishers, 3 J. WORLD INTELL. PROP. 97, 105-06 (2000). But, even if free copying were permitted, society as a whole would bear that cost. If educational institutions bear the cost of reproduction, the ultimate bearer of that cost will depend upon the means by which the educational system is funded. 
restricting access to class students ${ }^{303}$ or requiring payment of some license fee to Appletart (but denying an injunction). ${ }^{804}$ The former measure interferes to some extent with the educational philosophy of the Caledonian University, but permits it to continue its core mission. The latter measure fails to provide Appletart with full exclusive rights in her works, which (even with the grant of a license to others) would ordinarily permit her to deny certain individuals authority to reproduce her works. ${ }^{305}$ Which of these solutions should be adopted might depend upon the extent to which technological measures would interfere with the educational mission (as to which, cost would be relevant), ${ }^{3,6}$ and the extent to which it would be possible to make the value of the license reflect the losses that Appletart would suffer.

Let us assume further that a U.S. web site, www.greatart.com, establishes a link to the university web site in Caledonia. Might the web site be liable to Appletart under U.S. law? Here, U.S. law is even less clearly developed; U.S. courts have not yet established the parameters of permissible linking. ${ }^{367}$ Two arguments for liability might be, first, that providing a hypertext link to an infringing site facilitates direct infringement by users in a manner that amounts to contributory in-

\$ A third alternative might be to deny access from the United States. Territorialists would support the imposition of such technological measures because this would create legal borders where none in fact exist. See Goldsmith, supra note 25, at 484-85 (presenting arguments in support of territorial regulation of internet transactions). This might appear to suggest an elegant solution to the problems caused by cyberspace, but this is descriptively and normatively unhelpful. At the practical level, such restrictions may be easily circumvented and at some level (although, to be sure, not simply because one person can circumvent them) they become ineffective. Normatively, this regressive approach discards one of the great social benefits of the internet, namely, the enhanced public access to a number of works throughout the world. See supra note 25.

Silf See Campbell v. Acuff-Rose Music, Inc. 510 U.S. 569, 578 n.10 (1994) (acknowledging that the goals of copyright law are not always best served by injunctive relief).

See Harper \& Row, Pubs., Inc. v. Nation Enters., 471 U.S. 539, 546-47 (1985) (recognizing that the grant by the author of a license to one licensee to publish his work does not prevent him stopping others from publishing without authorization, but holding that the unpublished nature of a work cuts against a finding of fair use).

Cf. Germany to Enforce Child-Friendly Internet, CHI. TRIB., July 5, 1997, $\$ 1$, at 4 (noting German law holding access providers liable if they are aware of content illegal in Germany and fail to "use technically possible and reasonable" measures to block that content).

${ }^{\$ 117}$ Cf. 17 U.S.C. $\$ 512$ (d) (Supp. IV 1998) (creating safe harbors for service providers who provide information location tools, conditioned upon compliance with several detailed requirements including lack of knowledge of infringement, no commercial benefit from the direct infringement, and removal of the link upon formal notification by copyright owner). 
fringement, ${ }^{308}$ or, second, that (if the link is not clean, but instead establishes a framed version of the infringing site) the framing link results in the creation of a derivative work. ${ }^{309}$ Although each of these theories has been presented to U.S. courts, the ensuing opinions have been largely unsatisfying. On one level, the theories can formally be supported: if the linker is aware of the direct infringement that it is facilitating (the user's alleged infringement), then the elements of contributory infringement are formally satisfied; if the link causes the reproduction of the protected work within an external frame, the work is arguably transformed or recast in a way that involves the preparation of a derivative work. ${ }^{310}$ Yet, the case endorsing the former theory failed to consider whether the user's acts of browsing, although prima facie infringement, might otherwise be excused..$^{311}$ And no

${ }^{308}$ See, e.g., Intellectual Reserve, Inc. v. Utah Lighthouse Ministry, Inc., 75 F. Supp. 2d 1290, 1294-95 (D. Utah 1999) (finding contributory liability where defendants "actively directed" the public to infringing works posted on the web). Other cases have been filed in the United States alleging copyright infringement based upon linking to an allegedly infringing site, but these have been dismissed without comment. See, e.g., Bernstein v. JC Penney Inc., 50 U.S.P.Q.2d 1063 (C.D. Cal. 1998) (involving links to an allegedly infringing site in Sweden); $c f$. Ticketmaster Corp. v. Tickets.com, Inc., 54 U.S.P.Q.2d 1344, 1346 (C.D. Cal. 2000) (noting that infringement does not occur by reason alone of "deep linking" to interior pages of plaintiff's web site). The classic statement of the doctrine of contributory infringement is that "one who, with knowledge of the infringing activity, induces, causes or materially contributes to the infringing conduct of another, may be held liable as a "contributory infringer."' Gershwin Publ'g Corp. v. Columbia Artists Mgmt., 443 F.2d 1159, 1162 (2d Cir. 1971); see also Sony Corp. of Am. v. Universal City Studios, Inc., 464 U.S. 417 (1984) (denying claim of contributory infringement where equipment used to facilitate copying, videocassette recorders, had a substantial noninfringing use). One Dutch court has premised copyright liability on providing links to infringing materials. See Religious Tech. Ctr. v. Dataweb B.V. and Spaink, No. 96/1048 (Dist. Ct. of the Hague, Civil Law Sector, June 9, 1999); see also IFPI Belgium v. Beckers, [2000] E.C.D.R. 440 (Ct. First Instance, 1999) (enjoining links to internet sites containing unauthorized MP3 files). Some scholars have commented (somewhat optimistically, I would suggest) that the decision would affect only publishers in Holland. See Dan Goodin, Scientologists' Copyright Suit Shapes Net Liability, CNET NEwS.COM, at http://news.cnet.com/news/0-1005-200-343442.html (June 9,1999 ). On the liability for linking under German and U.S. laws, see Torsten Bettinger \& Stefan Freytag, Civil Law Responsibility For Links, 30 I.I.C. 883 (1999).

${ }^{309}$ See Futuredontics, Inc. v. Applied Anagramics, Inc., 45 U.S.P.Q.2d 2005, 2009-10 (C.D. Cal. 1998) (denying defendant's motion to dismiss and reasoning that a framed link could constitute a derivative work); see also Ticketmaster Corp., 54 U.S.P.Q.2d at 1346 (noting that hyperlinking of itself involves no violation of the Copyright Act because it involves no copying).

${ }^{310}$ See 17 U.S.C. $\$ 106(2)$ (1994) (giving the copyright owner the exclusive right to prepare derivative works based upon the copyrighted work).

311 In one regard it is unsurprising that the Utah Lighthouse court failed to consider whether the act of browsing constituted the necessary direct infringement (or was protected, for example, by fair use). See Utah Lighthouse, 75 F. Supp. 2d at 1294 (failing to 
court considering either theory has given any significant attention to the question of whether linking might be accorded greater latitude given its centrality to the operation of the world wide web. ${ }^{312}$

Even if the U.S. courts were to find that linking to an infringing work gave rise to potential contributory infringement liability (depending upon the mental state of the linker), would it matter that the infringing work was found in Caledonia (where it was not considered infringing)? Under traditional analysis, it would be of no avail that the web site was in Caledonia because, as discussed above, this could by virtue of U.S. accessibility be reconceptualized as publication within the United States. That is, a related direct infringement in the United States could be made out under the traditional theory.

Application of the substantive law method might permit accommodation of the myriad interests that are implicated by this fact pattern, and it might also contribute to a converging international approach to the question of linking. The strength of the different national laws' position on linking would be considered; U.S. law is unsettled, and let us assume that Caledonian law is also undeveloped. ${ }^{313}$

consider the fair use doctrine when proceeding on the assumption that the act of browsing the infringing web site constituted infringement). In cases applying the predicate act theory to recover foreign profits, U.S. courts have (with one notable exception) failed to analyze whether the foreign acts for which recovery of damages was sought were actionable under the copyright law of the foreign country in question. See supra note 185 . To be sure, in recent cases considering whether the domestic authorization of foreign acts supported subject matter jurisdiction under the U.S. Copyright Act, the Ninth Circuit stressed that contributory infringement could only exist under the U.S. statute if there existed an actionable direct infringement. See Subafilms, Ltd. v. MGM-Pathe Communications Co., 24 F.3d 1088, 1092 (9th Cir. 1994) (en banc) ("Contributory infringement under the 1909 Act developed as a form of third party liability. Accordingly, there could be no liability for contributory infringement unless the authorized or otherwise encouraged activity itself could amount to infringement."). But in this latter context also, the Subafilms court considered whether a direct infringement action existed under U.S. copyright law rather than whether such a violation had occurred abroad under the foreign law in question. See id. at 1089.

${ }^{\text {s1: }}$ Cf. Kelly v. Arriba Software, 77 F. Supp. 2d 1116, 1121 (C.D. Cal. 1999) (suggesting that the new technological environment in which a defendant's use is occurring might alter the outcome of a fair use inquiry); DVD Copy Control Ass'n v. McLaughlin, No. CV 786804, 2000 WL 48512, at *4 (Cal. Super. Ct. Jan. 21, 2000) (declining to enjoin links to a DeCSS program that unlocked technological protection on DVD formatted motion pictures and noting that "links to other websites are the mainstay of the Internet and indispensable to its convenient access to the vast world of information"). See generally Richard Raysman \& Peter Brown, Recent Linking Issues, N.Y. L.J., Feb. 8, 2000 , at 3 (discussing the McLaughlin case).

\$1:3 As a general matter, U.S. copyright law tends to be more developed than other countries, especially in matters involving technologically advanced activities. Indeed, this has caused some foreign commentators to explore the extent to which regard should be had to U.S. case law even in domestic cases. See Aztech Sys. Pte Ltd. v. Crea- 
This would suggest that the interests of each state in the application of a rule closely approximating the currently unsettled rule of their own law are not strong. ${ }^{314}$ International law also provides few answers. Here, postnational practices may be particularly helpful because linking is uniquely a web-based activity. Reference to web norms will likely reveal that different types of linking are used: clean surface linking, clean deep links, and framing links. Each of these serves a different function in web-based business and communication models; but each is not equally essential to the viability of the web and thus to the value of encouraging authors to make the broadest possible dissemination of works (one of the purposes of the Berne Convention).

The solutions that a court might consider may therefore include regulation of the different types of linking that can be used in different settings, and again compromise solutions such as rights of compensation might be considered in lieu of injunctive relief. Although it is unclear which solution a court following the substantive law method would or should develop, it is clear that such a court would be afforded much greater flexibility than courts applying the alternative approaches canvassed by other scholars. The regressive technologist might mandate the taking down of the link unless a technological measure could be developed to restrict activation of the link by a user in the United States (which is not yet effectively possible) ${ }^{315}$ The territorialist would consider only whether there was publication in the United States and whether that was knowingly and substantially facili-

tive Tech. Ltd., 1996 F.S.R. 54 (Sing. High Ct. 1995) (using U.S. copyright case law in the absence of developed Singapore law), rev'd on other grounds, 1997 F.S.R. 491 (Sing. 1996); Estelle Derclaye, Software Copyright Protection: Can Europe Learn From American Case Law? Part I, 22 EUR. INTELL. PROP. REV. 7 (2000) (examining whether American precedents will be a useful guide for European judges). The internet may, however, have leveled out this tendency; notwithstanding the predomination of U.S. users of the internet, case law has been quite vigorous in surprisingly diverse locales. For example, the first case filed on the question of linking arose out of the activities of local newspapers on the Shetland Islands in the North Sea off the coast of Scotland. See Shetland Times Ltd. v. Wills, 1997 Sess. Cas. 316 (Outer House 1996) (Scot) (holding that linking could constitute copyright infringement). Few places are more physically remote.

${ }^{314}$ Cf. Offshore Rental Co. v. Cont'1 Oil Co., 583 P.2d 721, 727 (Cal. 1978) (explaining consideration of "history and current status" of state laws in applying "the comparative impairment approach to the resolution of true conflicts").

${ }^{315}$ One U.S. court has noted that, " $[w]$ here ... a new use and new technology are evolving, the broad transformative purpose of the use weighs more heavily than the inevitable flaws in its early stages of development." Kelly, 77 F. Supp. 2d at 1121. Under this reasoning, the Kelly court found that a "visual search engine" that copied images in the course of indexing images necessary to fulfill its search engine function was protected under the fair use doctrine notwithstanding that, in the early stages of development, the search engine engaged in copying that was not necessary to its function. Id. 
tated by the link. A "nerve center" theorist might be willing to apply U.S. law to the entire arrangement and order the taking down of the link. And the cyberisolationist would look only to the norms of cyberspace without consideration of the interests of the states involved or of the principles found by analogy in the international system.

\section{c. Advantages as an Instrument of Intermational Copyright Lawmaking}

This approach has several advantages as a means (but not the sole means) of internationalization of copyright. Using the substantive law method to develop international norms harnesses the generative faculty of international litigation. ${ }^{316}$ There is a public value to litigation beyond the resolution of disputes between warring private parties. ${ }^{317}$ Moreover, like activist WTO adjudication, using private law mechanisms to develop norms of copyright law applicable to international disputes permits attention to issues raised by new technology. The approach of "choosing" applicable law is inherently conservative; it ensures that innovations necessary to achieve the best substantive result take the form of manipulating conflicts rules rather than developing copyright rules. That is, forcing courts to decide between existing rules makes them more backward-looking. Using the substantive choice of law method as part of international lawmaking can supply the dynamism appropriately missing from classical public international lawmaking.

51" Of course, one might recognize the generative force of adjudication but be more skeptical of its value or worth. See generally DUNCAN KENNEDY, A CRITIQUE OF ADJUDICATION (FIN DE SIÈCLE) (1997) (discussing the ideology of adjudication).

${ }_{317}$ See Izumi Seimitsu Kogyo Kabushiki Kaisha v. U.S. Philips Corp., 510 U.S. 27, 40 (1993) (Stevens, J., dissenting) (suggesting restraints on the capacity of parties to settle their case on condition of vacating the lower court opinion, and noting that judicial opinions "are not merely the property of private litigants"). In this vein, in Creative Technology, Ltd. v. Aztech Sys. PTE, Ltd., Judge Ferguson dissented from the forum non conveniens dismissal of a copyright infringement litigation from the U.S. courts, deferring to the courts of Singapore, on the grounds that the dismissal deprived the U.S. courts of the opportunity to address an important and unresolved question of copyright law affecting computer software. 61 F.3d 696, 708 (9th Cir. 1995) (Ferguson J., dissenting).

31× Traditionally, choice of law and harmonization are cast as alternative means of accommodating international differences. Choice of law analysis involves difficult decisions where harmonization has failed to eradicate differences in national laws; harmonization of national laws reduces the importance of choice of law determinations where those determinations have become too troublesome or uncertain. The latter observation explains in part the recent explosion in copyright harmonization efforts. But the substantive law method would enlist one strategy in the cause of the other, by facilitating the convergence of different national rules applicable to international disputes. See infra note 319 (discussing the relevance of examination of common sources 
The substantive law method will achieve this, however, without incurring the costs associated with broad WTO lawmaking. In particular, the parties bringing private disputes to courts, and thus having input to the development of international norms, are likely to be more diverse (or at least different) from those having input into the conduct of WTO dispute settlement proceedings. The disintermediation involved in enabling direct input to the production of international norms by a number of groups will remove the filters that threaten to confine the range of voices heard in the public international lawmaking process. In this fashion, private international copyright lawmaking may claim to facilitate the pluralized perspective required by the range of contemporary social and economic activities now affected by copyright.

A further strength of this means of developing international norms is, ironically, its relative weakness. States would remain free to deviate from multinational standards developed by other countries' courts, ${ }^{319}$ although reference to the practices of other national courts devising international solutions would be encouraged. ${ }^{320}$ But any concordance with the standards of another court would be based upon the force of reason rather than trade sanctions, perhaps a more enduring basis for long-term convergence and acceptance of interna-

to convergence of results).

${ }^{319}$ The ability of national courts to deviate from the rules applied by foreign courts to international disputes both recognizes the value of national experimentation and acknowledges that the rules developed by national courts under this approach are, at bottom, local rules of law to be applied in international cases. This does not undermine the project of internationalization, in support of which I advance this proposal. To be sure, the lack of a centralized superior court (such as the European Court of Justice or the U.S. Supreme Court) to referee between competing solutions may delay imposition of a universal international rule. But long-term harmonization will as likely result from the conscious efforts of national courts to nudge closer to each other; well reasoned decisions of the courts of one country should have a magnetic attraction to courts in other countries. Harmonization by persuasion rather than centralized compulsion, coupled with the freedom to accommodate diverse national priorities, may ultimately be more enduring. And in the interim, it is likely that national courts following the substantive law method will converge to a far greater extent than national courts do at present, because they would be considering the same or similar norms and sources of law (as opposed to the purely national sources to which they presently look). In short, the differences between a French court applying an international rule and a U.S. court applying an international rule are likely to be significantly less than a French court applying French law and a U.S. court applying U.S. law. Differences that may remain are likely to be on the margins rather than in fundamental respects. Indeed, those differences may be not only an acceptable (reduced) cost but also a desirable recognition and accommodation of national difference within a global market.

${ }^{320}$ See supra note 263 (discussing the benefits of comparative analysis of decisions of foreign courts in the search for solutions). 
tional standards. ${ }^{321}$ Pending such convergence, there would develop a range of alternative visions of international copyright in a way not possible with the publication of a WTO ruling. ${ }^{322}$ Reliance on this method of international lawmaking may thus permit a richer body of experience from which to construct ideal principles of copyright law than would the premature articulation of an international rule by a WTO panel (which may suppress the useful educational role of disparate national systems as comparativist experiments).

Indeed, the "weak" nature of this form of developing appropriate international norms affords important latitude also to the state whose courts articulate the standard. Unlike a WTO dispute settlement ruling, a court decision articulating international standards is more readily subject to legislative reversal, and thus more closely linked to the democratic process.

\section{d. Troublesame Issues}

So what has in the past prevented the adoption of this approach in conflicts of laws generally? What constrains courts to choose (and scholars to suggest that courts choose) between existing rules? Why is the multinational setting of the facts a variable that is treated differently from any other factual variable? I discuss three possibilities here: effect on certainty, the legitimacy of judicial lawmaking, and inherent biases in judicial lawmaking.

\section{i. Certainty}

The question of certainty is important. Indeed, participants in copyright industries might be willing to exchange some optimality of legal rules ex post for certainty ex ante. ${ }^{323}$ But to the extent that such

${ }^{121}$ See H. Lauterpacht, The So-Called Anglo-American and Continental Schools of Thought in International Law, 12 BRT. Y.B. INT'L L. 31, 52 (1931) (arguing that the power of judicial precedent is "in the long run not greater than the inherent value of the legal substance embodied in it"); cf. Dreyfuss \& Lowenfeld, supra note 99, at 332 (suggesting that the work of the panels and Appellate Body "should be carried on with great care in the intellectual property area-terra incognita for the GATT/WTO system-with attention not only to the outcome of a given case but to the persuasiveness of the reasoning and explanations, for the parties and for the wider interests at stake").

${ }^{322}$ See supra Part II.C.2.d.ii (suggesting that activist WTO lawmaking may undermine the role of national copyright laws as laboratories for an international system).

${ }^{32.3}$ See Dreyfuss \& Lowenfeld, supra note 99, at 278 (" $[\mathrm{T}]$ he nature of the innovation business is such that investments are made far in advance of commercialization. If intellectual property law is to function as intended-to encourage investment in research, development, dissemination, technical training, and technological infrastruc- 
participants are repeat actors, the benefit of such a calculation is diminished with every act of repetition. Thus, in the long term some ex ante uncertainty might be worth the gains in terms of aptness of legal rules. Moreover, current choice of law analysis arguably may induce less predictability and certainty than the method proposed here. ${ }^{324}$

The proposal advanced here would not be the first time that choice of law jurisprudence has cast off an ill-fitting raiment knowing that it will be some time before a custom-made replacement is available. In Neumeier v. Kuehner ${ }^{325}$ the New York Court of Appeals reviewed the choice of law revolution that it had in part ignited nine years earlier in Babcock $v$. Jackson ${ }^{326}$ with its rejection of the invariable application of the lex loci delicti in tort law:

When ... we rejected the mechanical place of injury rule in personal injury cases because it failed to take account of underlying policy considerations, we were willing to sacrifice the certainty provided by the old rule for the more just, fair and practical result that may best be achieved by giving controlling effect to the law of the jurisdiction which has the greatest concern with, or interest in, the specific issue raised in the litigation.... In consequence of the change effected-and this was to be anticipated—our decisions in multi-state highway accident cases ... have, it must be acknowledged, lacked consistency....

The single all-encompassing rule which called, inexorably, for selection of the law of the place of injury was discarded, and wisely, because it was too broad to prove satisfactory in application. There is, however, no reason why choice of law rules, more narrow than previously devised, should not be successfully developed, in order to assure a greater degree of predictability and uniformity, on the basis of our present knowledge and experience.

The court thus concluded that "the time has come . . . to endeavor to minimize what some have characterized as an ad hoc case-by-case approach by laying down guidelines, as well as we can, for the solution

ture-it must be made predictable long before disputes occur.").

${ }^{324}$ See Reichman \& Samuelson, supra note 25, at 112 n.279 (noting the complexity of choice of law in copyright); $c f$. Kermit Roosevelt III, The Myth of Choice of Law: Rethinking Conflicts, 97 MICH. L. REv. 2448, 2449 (1999) (commenting that "[c]hoice of law is a mess. That much is a truism."). The extent to which the approach sketched in this Article endangers the certainty required for international commercial transactions must be assessed in comparison to alternative choice of law approaches. A formal commitment to territorialism in the current social and economic climate will result in easy forum shopping, with the attendant uncertainties that flow from that activity.

31 N.Y.2d 121 (1972).

${ }^{326} 12$ N.Y.2d 473, 484 (1963) (discarding the prior steadfast application of the choice of law rule based on the lex loci delicti, and holding that the applicable choice of law rule should also reflect consideration of other factors).

${ }^{327}$ Neumeier, 31 N.Y.2d at 127. 
of guest-host conflicts problems." ${ }^{328}$ Importantly, the court noted the role that cases presented to the court and resolved through such an "ad hoc" approach played in developing these new "rules": "Babcock and its progeny enable us to formulate a set of basic principles that may be profitably utilized, for they have helped us uncover the underlying values and policies which are operative in this area of the law." The court thus acknowledged several steps in the process of constructing a choice of law approach that is both flexible and fair. First, the rigid approach must be torn down if an improved construct is to be erected. Second, we must be willing to accept a period in which there is a degree of "rubble" before the new construct is discovered and/or created..$^{334}$ Third, a new construct will arise. ${ }^{331}$ And, fourth, the bricks used to construct a new approach are made out of the raw material of actual disputes presented to the court.

This last part of the process is particularly important. The Neumeier court acknowledged that the candid serial resolution of factually situated disputes under a degree of judicial discretion, without the ties of overly formalistic rules, helps to uncover the values and policies that are most appropriately to be given weight by courts. Having uncovered those values, courts "may proceed to the next stage in the evolution of the law-the formulation of a few rules of general applicability, promising a fair level of predictability." ${ }^{382}$ The facade of copyright rules based upon territoriality needs to be stripped away, and a new approach constructed. Some uncertainty is an inevitable, but worthwhile, short-term cost.

One particular certainty-based concern is worthy of mention. If courts adopt a rule that in international copyright disputes they will consciously take into account considerations other than domestic U.S. copyright law, parties in domestic litigation with unfavorable positions

sid $I d$.

${ }^{324} I d$.

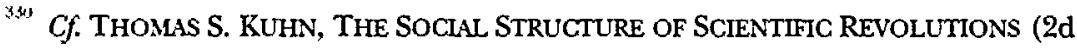
ed. 1970) (discussing development of new paradigms in sciences).

In this, the legal construct will parallel the reconstruction of social rules when the existing social structure is pulled down. See FRANCIS FukUYAMA, THE GREAT DISRUPTION: HUMAN NATURE AND THE RECONSTITUTION OF SOCIAL ORDER 263-77 (1999) (recounting the history of past "Great Disruptions" and the reconstitutions of social order that they engendered); $c f$. DAVI HAKKEN, CYBORGS@CIBERSPACE? AN ETHNOGRAPHER LOOKS TO THE FUTURE 131 (1999) (noting that the "hegemony of the nation is being deconstructed in current social practice as well as theory, but as yet neither 'reconstructed' terminology for describing macro-social relations nor viable structures for democratic control have emerged").

${ }^{392}$ Neumeier, 31 N.Y.2d at 128. 
under that law might frame their dispute as international in nature in order to persuade courts to ignore U.S. law. ${ }^{333}$ This concern has, in fact, been addressed by the U.S. Supreme Court. In Scherk v. AlbertoCulver, Co., the Court considered whether to enforce an arbitration clause where one party to the contract wished to bring a private action for securities fraud. ${ }^{344}$ Previously, the Court had held that private securities claims could not be submitted to arbitration because they implicated matters of public interest inappropriate for determination outside the court system. ${ }^{395}$ The Court distinguished its earlier decision on the ground that it had involved a domestic claim, whereas Scherk involved an international commercial matter. ${ }^{396}$ Justice Douglas dissented on the ground that this opened a Pandora's box in that parties could avoid the effect of the Court's earlier decision, denying the right to arbitrate, simply by invoking an international contact. ${ }^{397}$ The majority responded by noting that courts would have to develop case law as to whether a set of facts is closer to the domestic fact pattern or to the international fact pattern. ${ }^{338}$ The Supreme Court thus appears unperturbed by this aspect of the judicial task. That said, in setting the parameters of what should be regarded as national or multinational, one might look at how the issue will affect the certainty of commercial transactions.

In one sense, developing a separate set of rules for international copyright cases comports closely with a key pragmatic component of the Berne Convention. Under the Convention, while the substantive minima are mandatory with respect to foreign Unionist authors, Berne members may derogate from these minimum protections for their own nationals (or works) on the theory that domestic norms may

${ }^{333}$ Forum shopping would also likely be reduced because of the convergence of sources to which different national courts would look in international cases. See supra note 319 .

${ }^{334}$ See 417 U.S. 506, 519-20 (1974) (holding that the agreement of the parties to arbitrate any dispute arising out of their international commercial transaction is to be respected and enforced by the federal courts in accord with the explicit provisions of the Arbitration Act).

${ }^{395}$ See Wilko v. Swan, 346 U.S. 427, 434-35 (1953) (holding that an agreement to arbitrate could not preclude a buyer of a security from seeking a judicial remedy under the Securities Act of 1933).

${ }^{336}$ See Scherk, 417 U.S. at 515 (explaining that a crucial difference between the agreement in Wilko and the one in Scherk is that the Scherk agreement was truly international).

${ }^{337}$ See id. at 528-29 (Douglas, J., dissenting) (fearing the "invocation of the international contract' talisman").

${ }^{388}$ See id. at 517 n.11. 
apply to purely domestic disputes. ${ }^{339}$ The United States has taken advantage of this provision, for example, in requiring registration as a prerequisite for an infringement suit only for domestic authors (or works). ${ }^{3: 4}$ But this is generally more difficult to justify politically. It might be easier to justify if the more generous international norm applied equally to local and foreign authors operating in the same multinational environment; the differentiating variable would (under this proposal) be the domestic or multinational nature of the case rather than nationality or place of publication (as is presently the case).$^{341}$

Finally, concerns regarding the effect that the substantive law method would have on commercial certainty seem unwarranted when the one area in which anything approximating this approach is now being pursued with enthusiasm is international commercial arbitration.

\section{ii. Legitimacy}

The democratic legitimacy of the process and its effect on substantive copyright law might, however, be worth pondering further. Any proposal that judges candidly engage in lawmaking is likely to raise concerns of legitimacy. ${ }^{342}$ Yet, judges do make law, and they have

${ }^{339}$ See Berne Convention, supra note 15, art. 5(1), (3), 1161 U.N.T.S. at 35 (requiring that authors shall enjoy, in countries of the Union other than the country of origin, the rights which their respective laws do now or may grant to nationals, as well as the rights specially granted by the Convention, for works protected by the Convention but that protection in the country of origin is governed by domestic law). Existing copyright choice of law analysis may reference nationality in several ways. See Itar-Tass Russian News Agency v. Russian Kurier, Inc., 153 F.3d 82, 90-91 (2d Cir. 1998) (considering nationality as relevant to the law applicable to the question of copyright ownership). And U.S. courts have taken the nationality of parties into account in other ways without, they have argued, offending the principle of national treatment. See Murray v. British Broad. Corp., 81 F.3d 287 (2d Cir. 1996) (rejecting the argument that the preference given to choice of forum by a domestic, but not foreign, plaintiff in forum non conveniens analysis was inconsistent with the national treatment principle).

S4t" See 17 U.S.C. $\$ 411$ (1994) (requiring registration of copyright claims before institution of actions for infringement of U.S. works); see also 17 U.S.C. $\$ 104$ A (Supp. IV 1998) (limiting the restoration of copyrights in certain works mandated by TRIPS to non-U.S. works from a Berne or WTO country).

${ }^{311}$ Moreover, a line between domestic and international settings, rather than domestic or foreign nationals, better reflects social realities. Although the ability of Berne countries to derogate from Berne minimum levels of protection attempts to ensure that "domestic norms may continue to apply to purely domestic copyright controversies," Ginsburg, supra note 3, at 270, a nationality-based line does not effectuate that consideration.

${ }_{942}$ This concern might be accommodated in the means by which the proposal advanced in this Article is implemented. Although courts (in the United States) can 
long made copyright law. Courts have been an important factor in shaping the contours of domestic U.S. copyright law and policy; the fair use doctrine is a notable example. ${ }^{343}$ The more pertinent question is whether establishing international copyright norms, and applying laws other than those promulgated by Congress, somehow diminishes the legitimacy of the proposal in this Article.

A nexus between the law applied to a citizen and that citizen's participation in the political process which gives rise to that law is important. $^{344}$ My proposal accommodates this concern in three primary

adopt copyright "choice of law rules" as a matter of federal common law, see supra text accompanying note 207 , there exist other more cautious means by which to implement the proposal advanced in this Article. The legitimacy of the proposal might be enhanced either by unilateral congressional legislative instruction to adopt such an approach or by the conclusion of a multilateral treaty under which signatory countries agree to implement such an approach. Cf. Geoffrey C. Hazard, Jr. \& Michele Taruffo, Transnational Rules of Civil Procedure: Rules and Commentary, 30 CORNELI INT'L L.J. 493, 509 (1997) (discussing the means of implementing proposed Transnational Rules of Civil Procedure, which would apply in national courts where parties were nationals of different countries). The former approach-unilateral legislation incorporating such standards in causes of action for copyright infringement involving an international component-is politically unlikely. But the Alien Tort Claims Act ("ATCA"), 28 U.S.C. $\S 1350$ (1994), which creates a cause of action for aliens in the United States based upon violations of the "law of nations," might be a rough model in this regard. For a discussion of the ATCA, see Chibundu, supra note 233. The latter alternative-to conclude an international agreement directing judicial attention to international standards in cases within its scope-may mirror the instruction that some scholars have seen in the Convention on the International Sale of Goods ("CISG"). See Van Alstine, supra note 5, at 761 (describing the CISG). This approach might enhance domestic political acceptability at a time when protection of U.S. intellectual property interests is assuming greater political prominence. In other areas of international commerce, efforts are continuing apace to conclude multilateral treaty systems modeled on the CISG. These agreements, like the CISG, concentrate on the articulation of universal substantive rules on such matters as accounts receivable financing, and thus have encountered delays in compromising common law and civil law philosophies on substantive legal concepts (such as nonpossessory security interests). A treaty commitment to the substantive law method in international copyright cases might necessitate fewer ex ante compromises, leaving difficult questions to the courts in particular factual settings. Agreeing to implement the substantive law method does not bind signatory states to any particular substantive vision of copyright law. Moreover, it provides signatory states greater assurance that if foreign courts assume jurisdiction over an international copyright case in which it has an interest, its interest will be taken into account. The depth of that assurance would be tested only if signatory states also concluded an international convention on recognition and enforcement of judgments. See supra note 191 (discussing the proposed Hague Convention).

${ }^{343}$ See Folsom v. Marsh, 9 F. Cas. 342 (C.C.D. Mass. 1841) (No. 4901) (developing the fair use doctrine); H.R. REP. NO. 94-1476, at 65 (1976), reprinted in 1976 U.S.C.C.A.N. 5659, 1976 WL 14045 (discussing the fair use doctrine). See generally WILliaM F. PATRY, THE FAIR USE PRIVILEge IN COPYRIGHT LAW (2d ed. 1985).

${ }^{344}$ Cf. Thomas Mackay Cooper, The Common and the Civil Law-A Scot's View, 63 HARV. L. REV. 468, 475 (1950) (noting that "[p]ublic respect for law, without which 
ways. First, as noted above, this international lawmaking will exist within a national setting. The courts that develop and apply this international law will not be responsible to an amorphous international society. They will be nationally appointed, nationally reviewed, and nationally influenced. The national courts that develop international norms are connected to a national legislative or political unit that can revisit apparent judicial over-reaching. Indeed, framed alternatively in the language of Walter Wheeler Cook's local law theory, this remains the application of forum law. ${ }^{345}$ That is, in terms of that theory, it merely endorses the incorporation of foreign learning into the judicial development of domestic law governing a particular (international) fact pattern.

Second, the legitimacy of the endeavor is surely enhanced by applying an international solution to an international problem, rather than squeezing matters into a domestic U.S. model and deciding it according to domestic U.S. norms. The substantive law method treats the "applicable law" as a truly international construct, thus reflecting a growing social reality that citizens of the global community will achieve input into international norms in a variety of different ways.

Third, the approach that I propose can be no more offensive to national sovereignty than the wholesale application of foreign law. If it is consistent with our existing notions of judicial duty either to apply the forum law or the law of another state, the application of a law falling between that of the forum and the other state cannot be more offensive to notions of democratic legitimacy or state sovereignty.

\section{iii. Biases Inherent in the Nature of International Litigation}

To some extent, the proposal advanced in this Part of the Article reflects an underlying preference for new issues of copyright law to be addressed by courts rather than legislatures. That is, it might be easier for competing claims to be weighed by considering a particular set of facts rather than in the abstract context of a legislative or treaty debate. An analysis of the appropriate intrusion of national norms into international settings probably cannot be answered deductively from first principles of globalized society. And litigation may accommodate

law cannot exist and civilization itself is threatened, depends upon the law's ability to satisfy the average man's feeling for common justice visibly done").

355 See WALTER WHEELER COOK, THE LOGICAL AND LEGAL BASES OF THE CONFLICT OF LAWs 20-21 (1949) (suggesting that when a court applies a rule of foreign law, it is in fact applying its own law but adopting as its own law a rule identical or similar to the law of that foreign state). 
the range of interests involved in modern copyright disputes in a more even-handed fashion than is possible through extensive reliance on the legislative process. If lobbying efforts are not equal in the domestic context, the disparities may become even greater when the number and geographical location of lawmaking fora are increased. ${ }^{346}$

There is a danger, however, that an understanding of appropriate international copyright norms developed through common law adjudication would become court-centered, with various other attendant biases. ${ }^{347}$ For example, I argue in this Article that empowering judges to incorporate international norms in their adjudicatory activities is helpful in keeping copyright law current with rapidly changing technologies. But not all scholars have seen courts as faster and more responsive than legislative articulation. ${ }^{348}$ And to be sure, the necessarily random manner in which issues come to courts precludes a compre-

${ }^{346}$ See D.J.G. Visser, The Netherlands, in COPYRIGHT IN CYBERSPACE 124, 131 (Marcel Dellebeke ed., 1997) (discussing the extent to which lobbying affects available exceptions in Dutch copyright law). On the other hand, one could argue that public interest groups previously insufficiently funded or staffed have had greater impact on recent legislative efforts because enhanced communication has enabled pooling of resources.

${ }^{347}$ To the extent that this proposal rests upon similar approaches being adopted in other countries, a celebration of common law forms of adjudication may seem unduly parochial and dismissive of the culture of civil law systems. Conventional understanding of civilian systems emphasizes the more mechanical nature of judging. But civil law judges make law just as much as their common law counterparts. See generally JOHN HENRY MERRYMAN, THE GIVIL LAW TRADITION: AN INTRODUCTION TO THE LEGAL SYSTEMS OF WESTERN EUROPE AND LATIN AMERICA (2d ed. 1985) (exploring the history of the civil law tradition in Western Europe and Latin America); KONRAD ZWEIGERT \& HEIN KóTZ, INTRODUCTION TO COMPARATIVE LAW (Tony Weir trans., 3rd rev. ed. 1998) (surveying the field of comparative law). Indeed, von Mehren cites French court decisions in the 1920s among the few examples of the substantive law method in operation. See von Mehren, Special Substantive Rules, supra note 229, at 363.

${ }^{348}$ See, e.g., Cooper, supra note 344, at 474-75 (arguing that "[f]undamental transformations ... cannot be worked out empirically by the Anglo-Saxon method with its reliance upon slowly developing tracts of judicial decisions evolved with infinite caution by generations of elderly and timorous judges conditioned by Victorian ideals"). As the latter part of Cooper's comment suggests, this critique may reflect not the inherent capacity of common law judging but the composition of the English bench (especially in the nineteenth century). This may also be true of Dicey's wry observation, quoted by Cooper, that in the nineteenth century "statute law reflected the public opinion of yesterday; and judge-made law, the opinion of the day before." Id. at 474. And another institutional restraint in the nineteenth century may have been the perceived need to erect a veneer that judges were engaged in incremental revelation of historically existent law rather than prospective production of law. English choice of law attitudes of the day (essentially, apply English law) did not encourage judicial innovation, and indeed neither do current methods. The method suggested here is consciously empowering, and in part thus responds to the critique of such common law judges (and perhaps of common law judging). 
hensive systematization of appropriate conduct in new fields of activity; this is a matter that legislatures do better.

Two rebuttals can be tendered to this critique of the judicial role. First, I view this role as complementary to legislative systematization and not exclusive of it. Indeed, the pace of legislative progress may be aided greatly by a willingness to defer certain narrower issues to later adjudicatory arenas. Second, legislation and treaty-making are not the same. As I demonstrated in Part I of this Article, copyright treatymaking historically has been a codifying exercise, and when it moves beyond such limited ambition it is subject to significant criticism. Thus, the comparison of the means by which international norms are incorporated into copyright law is not solely a comparison of legislation and adjudication.

There may also be a concern that, if national courts are encouraged to look to the approaches of other countries in developing norms of international copyright law, the natural tendency to look for ready-made answers may embed a bias toward states (such as the United States) with substantial litigation of such questions. Those states would likely have mature intellectual property systems. ${ }^{349}$ This is a legitimate concern. ${ }^{350}$ It is important to stress, therefore, that this is a complementary strategy designed to ensure that international copyright lawmaking does not run the risks associated with the new model of public international copyright lawmaking.

\section{CONCLUSION}

We need a broader understanding of international copyright lawmaking. That broader vision may be realized in various ways. The mere limitation of WTO influence will in itself permit progress toward that vision by leaving open issues for continuing debate and avoiding premature entrenchment of fundamental norms. But this (intentional) gap may also be affirmatively filled, in a more cautious and appropriate way, and with a more pluralistic vision of copyright, by other

${ }^{349}$ See id. at 469 (noting the decline of Roman law as a source of solutions when other systems became available to provide alternative solutions from which countries wrestling with questions for the first time could "borrow").

$\$ 500$ It may be that countries that engage in a systematized codification of international case law would be more likely to provide a ready model for adoption. See id. at 472 (noting that "systems codified and applied on the civilian principle" have been adopted freely throughout the world but "Anglo-American common law by contrast has been imposed by conquest and has followed colonization"). The EU experience in the last decade may confirm this suggestion. 
mechanisms. These include not only the traditional public lawmaking vehicles of the WIPO and other international copyright institutions, but also private law mechanisms. Private law dispute resolution mechanisms can, and should, assume a greater and more direct role in the international lawmaking process. National courts have a role to play in the creation, recognition, and enforcement of global norms. A new approach to choice of law can facilitate that role. 